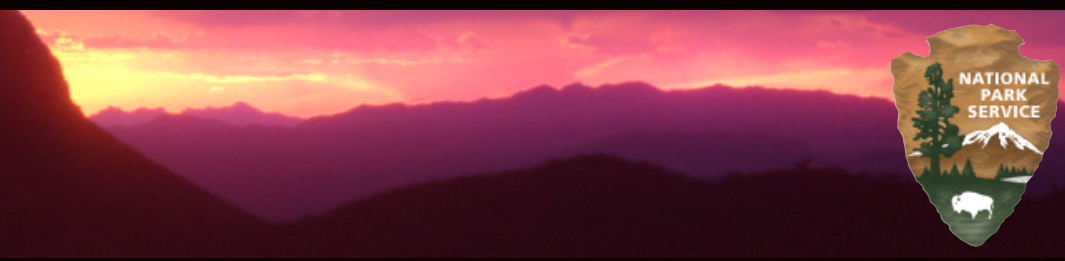

In Cooperation with the University of Arizona, School of Natural Resources

\title{
Vascular Plant and Vertebrate Inventory of Montezuma Castle National Monument
}

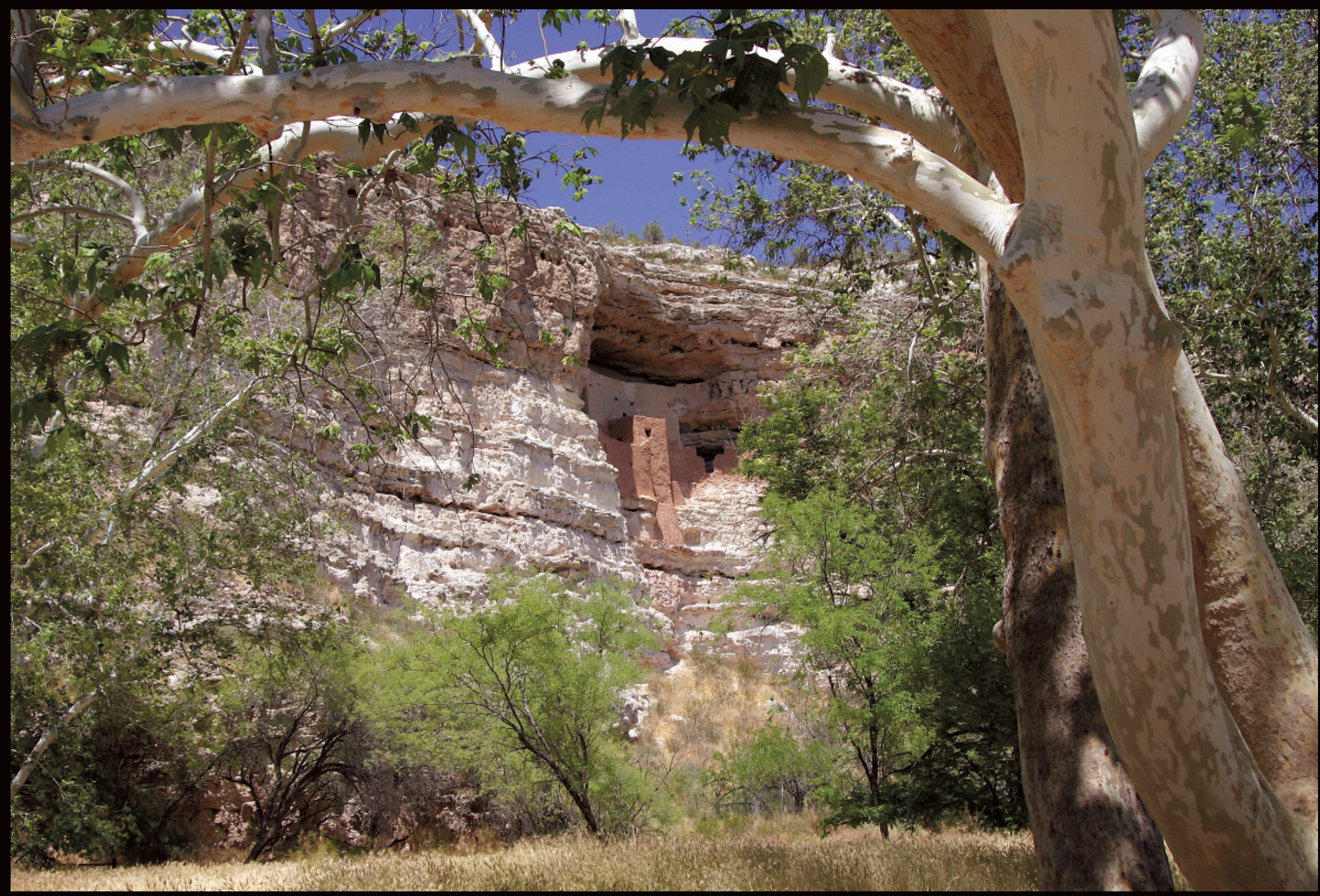

Southwest Biological Science Center

Open-File Report 2006-1163

November 2006

U.S. Department of the Interior

U.S. Geological Survey

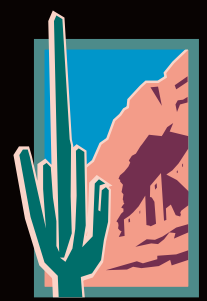

National Park Service 



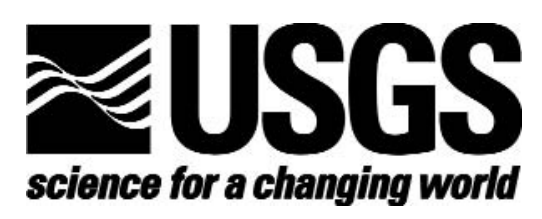

In cooperation with the University of Arizona, School of Natural Resources

\section{Vascular Plant and Vertebrate Inventory of Montezuma Castle National Monument}

By Cecilia A. Schmidt, Charles A. Drost, and William L. Halvorson

Open-File Report 2006-1163

November, 2006

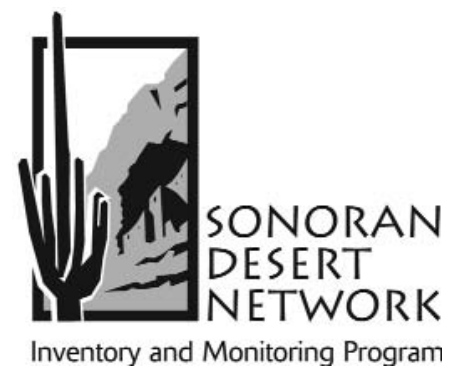

USGS Southwest Biological Science Center Sonoran Desert Research Station University of Arizona

U.S. Department of the Interior

U.S. Geological Survey

National Park Service School of Natural Resources 125 Biological Sciences East Tucson, Arizona 85721 


\section{U.S. Department of the Interior \\ Dirk Kempthorne, Secretary}

\section{U.S. Geological Survey}

Mark Myers, Director

U.S. Geological Survey, Reston, Virginia: 2006

Note: This document contains information of a preliminary nature and was prepared primarily for internal use in the U.S. Geological Survey. This information is NOT intended for use in open literature prior to publication by the investigators named unless permission is obtained in writing from the investigators named and from the Station Leader.

\section{Suggested Citation}

Schmidt, C. A., C. A. Drost, and W. L. Halvorson 2006. Vascular Plant and Vertebrate Inventory of Montezuma Castle National Monument. USGS Open-File Report 2006-1163. U.S. Geological Survey, Southwest Biological Science Center, Sonoran Desert Research Station, University of Arizona, Tucson, AZ.

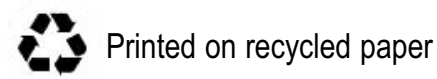

Cover photo: Montezuma Castle NM file photo 


\section{Authors}

Cecilia A. Schmidt and William L. Halvorson

USGS Southwest Biological Science Center

Sonoran Desert Research Station

and School of Natural Resources

125 Biological Sciences East, Building 43

University of Arizona

Tucson, Arizona 85721

Charles A. Drost

USGS Southwest Biological Science Center

Colorado Plateau Research Station

2255 N. Gemini Drive

Flagstaff, Arizona 86001

\section{U.S. Geological Survey SBSC Sonoran Desert Research Station Personnel}

Charles van Riper III, Station Leader

Steve P. Gloss, Ecologist

William L. Halvorson, Research Ecologist

Cecil R. Schwalbe, Ecologist

Michael R. Kunzmann, Ecologist (Emeritus)

Kathryn Thomas, Ecologist

Pamela Nagler, Physical Scientist

Phil Rosen, Ecologist

\section{Program and Expertise Areas of USGS and UA Personnel}

Administration \& Outreach

Kate Leonard

Jennifer Meador

Wendy Parrish

Emily Sherbrooke

Charles van Riper III

Avian Ecology

Claire Crow

Glenn Johnson

Chris O'Brien

Brian Powell

Charles van Riper III

Data Management

Brent Sigafus

Ecology of Amphibians \& Reptiles

Kevin Baker

Cristina Jones

Dave Prival

Phil Rosen

Cecil Schwalbe

Brent Sigafus
Fire Management

Dennis Suhre

Cori Dolan

James Feldmann

Bill Halvorson

Invasive Species Research

Patricia Guertin

Jim Malusa

Phil Rosen

Cecil Schwalbe

Brent Sigafus

Dennis Suhre

Kathryn Thomas

Inventory \& Monitoring

Patricia Guertin

Bill Halvorson

Pamela Nagler

Brian Powell

Cecilia Schmidt

Vegetation Mapping \& Ecology

Patricia Guertin

Bill Halvorson

Jim Malusa

Kathryn Thomas 


\section{Table of Contents}

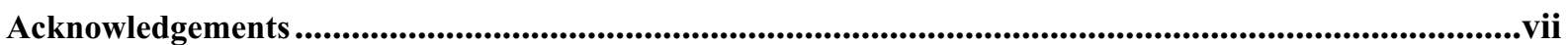

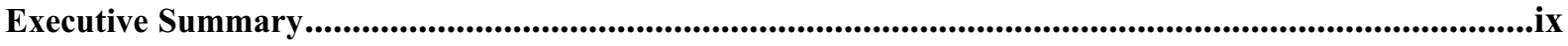

Chapter 1: Introduction to the Biological Inventories............................................................................1

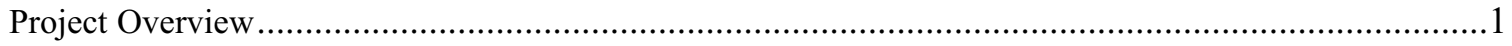

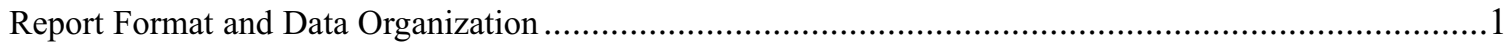

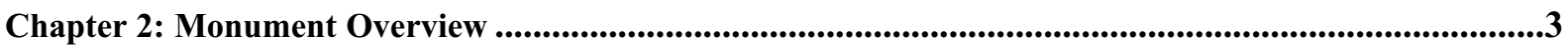

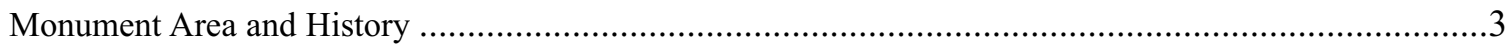

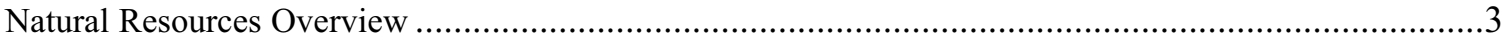

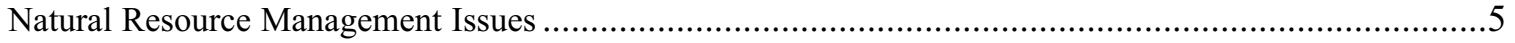

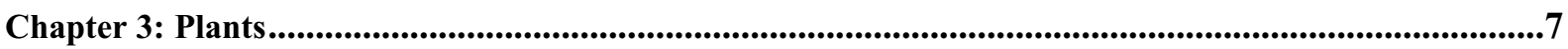

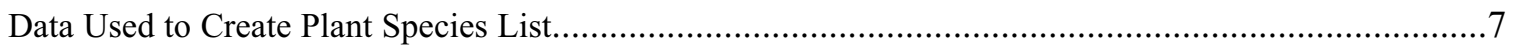

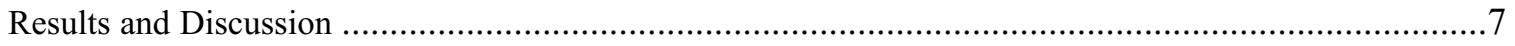

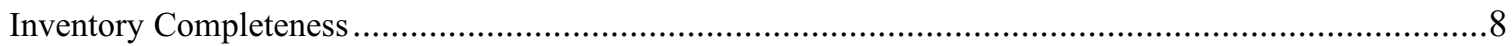

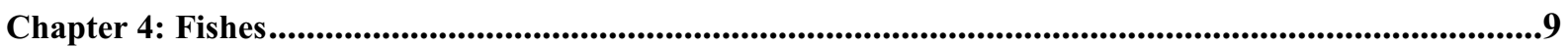

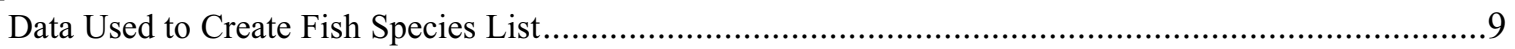

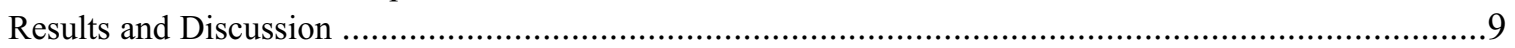

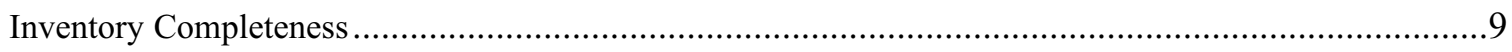

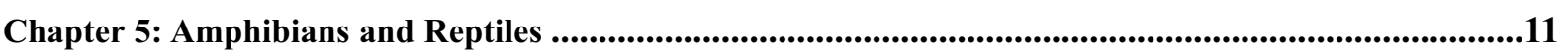

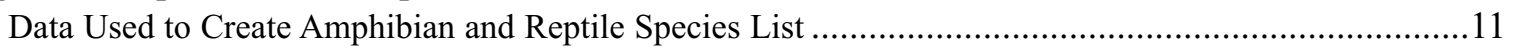

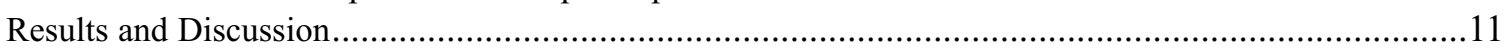

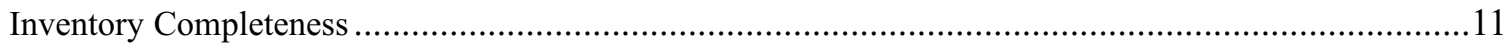

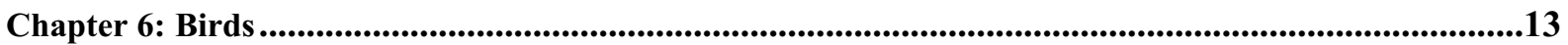

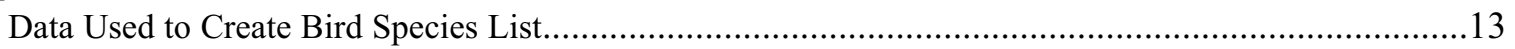

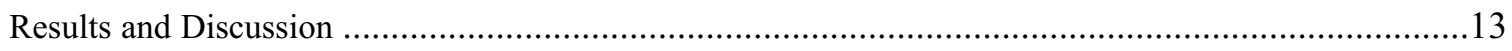

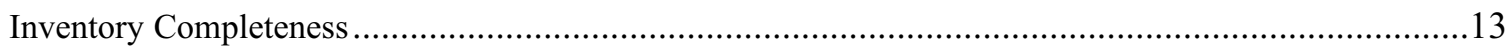

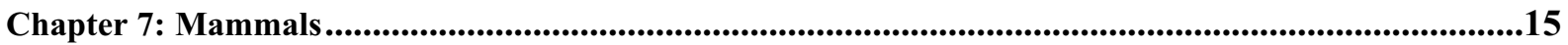

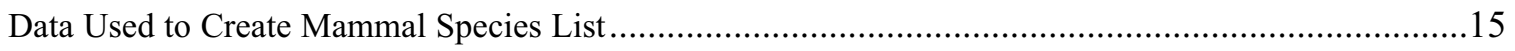

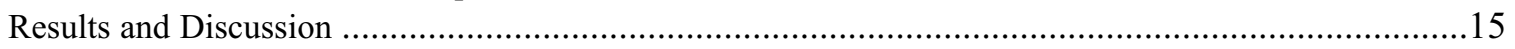

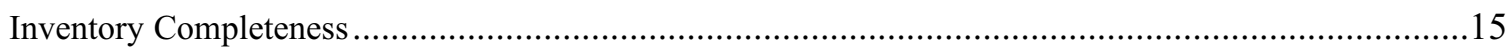

Chapter 8: Management Implications.....................................................................................................17

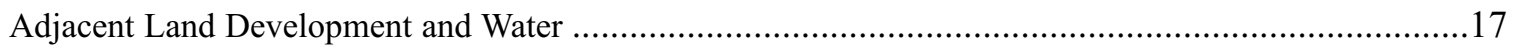

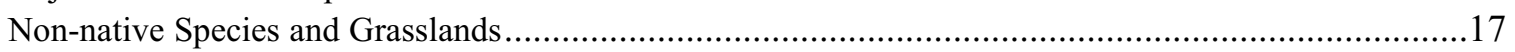

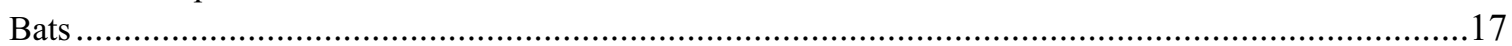

Chapter 9: Additional Inventories and Research ..................................................................................19

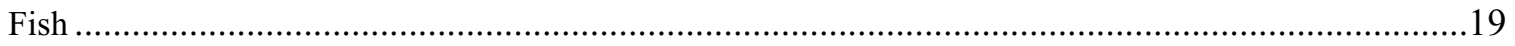

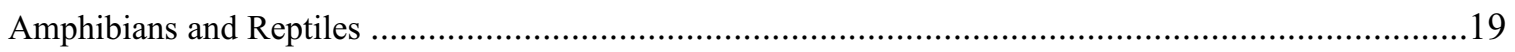

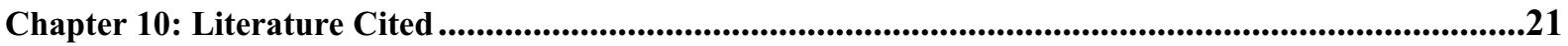




\section{List of Tables}

Table 1. Summary of vascular plant and vertebrate inventories at Montezuma Castle NM.

Table 1.1 Museums that were queried (in 1998) for vertebrate voucher specimens with "Arizona" and "Montezuma Castle National Monument" in the collection location.

Table 2.1. Average monthly climate data for Montezuma Castle NM, 1938-2005 ...............................................

\section{List of Figures}

Figure 2.1. Location of Montezuma Castle NM in Arizona and aerial photographs of the Castle and Well units

\section{List of Appendices}

Appendix A. Plant species observed or collected at Montezuma Castle NM, Castle unit ....................................23

Appendix B. Plant species observed or collected at Montezuma Castle NM, Well unit........................................34

Appendix C. Fish species observed or collected at Montezuma Castle NM..................................................43

Appendix D. Amphibian and reptile species observed or collected at Montezuma Castle NM..............................44

Appendix E. Bird species observed or collected at Montezuma Castle NM....................................................45

Appendix F. Mammal species observed or collected at Montezuma Castle NM ...............................................50

Appendix G. Native fish species that have been extirpated (E) and non-native fish that no longer occur (NP) at

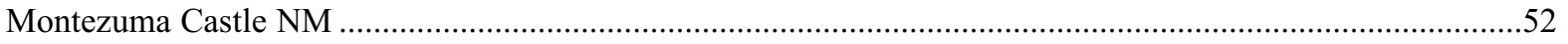

Appendix H. Amphibian and reptile species that may occur (P) or have been extirpated (E) at Montezuma Castle NM .

Appendix I. Bird species that may occur at Montezuma Castle NM .................................................................53

Appendix J. Mammal species that may occur at Montezuma Castle NM........................................................55

Appendix K. Voucher specimens from Montezuma Castle NM................................................................55 


\section{Acknowledgements}

Thanks to Superintendent Kathy Davis and all the staff at Montezuma Castle National Monument (NM) for their administrative support of our program. This project resulted from the collaboration of many people at the University of Arizona (UA), the National Park Service (NPS), and the U.S. Geological Survey (USGS) and was facilitated by the Desert Southwest Cooperative Ecosystem Studies Unit (DSCESU). Andy Hubbard at the Sonoran Desert Network (SDN) Inventory and Monitoring (I\&M) program and Larry Norris at the DSCESU provided administrative support for this project. Additional administrative support was provided by Cecily Westphal of the School of Natural Resources at the University of Arizona. Superintendent Kathy Davis played an instrumental role in this project by providing important early initiative.

Debbie Angell, Pamela Anning, Ryan Reese and Zuleika Valdez assisted in data entry and database design. Special thanks to Kristen Beaupre for creating figure 2.1.

We would like to thank the numerous ecologists who have contributed their time and knowledge to further our understanding of the flora and fauna of Montezuma Castle National Monument. Each species list we compiled was the result of hundreds of hours of field work by these dedicated ecologists. In particular, we acknowledge the investigators and field staff on the earlier inventory study: Peter Rowlands and Nancy Brian (plants); Linn Montgomery, Gloria Hardwick, and Bill Leibfried (fish); Erika Nowak (amphibians and reptiles); Laura Ellison (mammals); and Mark Sogge and Matthew Johnson (birds).

We received reviews on earlier drafts of this report from Kathy Davis, Andy Hubbard, and Larry Norris.

All mistakes or omissions are the responsibility of the authors. 


\section{Executive Summary}

We summarize past inventory efforts for vascular plants and vertebrates at Montezuma Castle National Monument (NM) in Arizona. We used data from previous research to compile complete species lists for the monument and to assess inventory completeness.

There have been 784 species recorded at Montezuma Castle NM (Table 1), of which 85 $(11 \%)$ are non-native.

In each taxon-specific chapter we highlight areas of resources that contributed to species richness or unique species for the monument. Of particular importance are Montezuma Well and Beaver and Wet Beaver creeks and the surrounding riparian vegetation, which are responsible for the monument having one of the highest numbers of bird species in the Sonoran Desert Network of park units. Beaver Creek is also home to populations of federally-listed fish species of concern. Other important resources include the cliffs along the creeks and around Montezuma Well (for cliff and cave roosting bats).

Based on the review of past studies, we believe the inventory for most taxa is nearly complete, though some rare or elusive species will be added with additional survey effort. We recommend additional inventory, monitoring and research studies.

Table 1. Summary of vascular plant and vertebrate inventories at Montezuma Castle NM.

\begin{tabular}{lcc}
\hline Taxonomic group & Number of species recorded & Number of non-native species \\
\hline Plants & 472 & 72 \\
\hline Fish & 9 & 5 \\
\hline Amphibians and Reptiles & 34 & 3 \\
\hline Birds & 211 & 4 \\
\hline Mammals & 58 & 1 \\
\hline Totals & 784 & 85 \\
\hline
\end{tabular}




\section{Chapter 1: Introduction to the Biological Inventories at Montezuma Castle National Monument}

\section{Project Overview}

Inventory: A point-in-time effort to document the resources present in an area.

In the early 1990 s, responding to criticism that it lacked basic knowledge of natural resources within parks, the National Park Service (NPS) initiated the Inventory and Monitoring Program (NPS 1992). The purpose of the program is to detect long-term changes in biological resources (NPS 1992). At the time of the program's inception, basic biological information, including lists of plants and animals, was absent or incomplete for many parks. In fact, as of 1994, more than $80 \%$ of national parks did not have complete inventories of major taxonomic groups (Stohlgren et al. 1995). The plant and animal communities and other natural resources of "cultural parks" like Montezuma Castle National Monument (NM) have been relatively neglected. However, these areas protect valuable biological communities. In many instances, the same features that drew early humans to the area also provide for rich biological communities, like the extensive riparian habitat at Montezuma Castle NM.

Species inventories have both direct and indirect value for management of the monument. Species lists are not only useful in resource interpretation and facilitating visitor appreciation of natural resources, but are also critical for making management decisions. Knowledge of which species are present, particularly sensitive species, and where they occur provides for informed planning and decision-making (e.g., locating new facilities). Thorough biological inventories provide a basis for choosing parameters to monitor and can provide baseline data for monitoring ecological populations and communities. In some cases, inventories may identify or provide data related to critical resources such as riparian areas that are valuable both intrinsically and as habitat for species of management interest.
An integrated, broad-based inventory of the vascular plants and vertebrates of Montezuma Castle NM was undertaken between 1991 and 1994 to provide information on current status, trends, and potential management concerns of the natural resources of the monument. Components of the inventory included plants, fishes, amphibians and reptiles, birds, and mammals. The work was a collaborative effort of researchers from Northern Arizona University and the U.S. Geological Survey (USGS) Colorado Plateau Research Station in Flagstaff, Arizona. This report, prepared by staff of the University of Arizona, the USGS Sonoran Desert Research Station in Tucson, Arizona, and the USGS Colorado Plateau Research Station in Flagstaff, Arizona, provides a thorough review and update of the previous inventory work.

\section{Goal}

The purpose of this study was to compile a complete list of vascular plants and vertebrates from existing sources.

\section{Administrative History}

The study plan for this project was developed through a cooperative agreement among the NPS, University of Arizona (UA), and USGS. It was funded through Task Agreement UAZ-173 (under Desert Southwest CESU cooperative agreement number CA 124800002).

\section{Report Format and Data Organization}

This report is intended to be useful for internal planning and outreach, and education. We report only common names (listed in phylogenetic sequence) unless we reference a species that is not listed later in an appendix; in this case we present both common and scientific names. For each taxonomic group we include an appendix of all species that have been recorded in the monument (Appendices A-F), and species that were likely present historically or that we suspect are currently present and may be recorded with additional survey effort (except for plants; Appendices G-J). Species lists are in phylogenetic sequence and include 
taxonomic order, family, genus, species, subspecies or variety (if applicable) and common name. Scientific and common names used throughout this document are current according to accepted authorities for each taxonomic group: Integrated Taxonomic Information System (ITIS 2004) and the PLANTS database (USDA 2004) for plants; Stebbins (2003) for amphibians and reptiles; American Ornithologists' Union (AOU 1998, 2003) for birds; and Baker et al. (2003) for mammals. Units of measurement are presented in accordance with the International System of Units.

\section{Species Conservation Designations}

We indicate species conservation designations by the following agencies: U.S. Fish and Wildlife
Service (responsible for administering the Endangered Species Act), Bureau of Land Management, U.S. Forest Service (Region 3), Arizona Game and Fish Department, and Partners in Flight (a partnership of dozens of federal, state and local governments, non-governmental organizations, and private industry).

\section{Voucher Specimens}

Although we did not collect voucher specimens for vertebrates, we searched for existing vouchers from Montezuma Castle NM in records from 23 natural history museums (Table 1.1; see Appendix K for results).

Table 1.1. Museums that were queried (in 1998) for vertebrate voucher specimens with "Arizona" and "Montezuma Castle National Monument" in the collection location. Collections in bold-faced type had specimens from Montezuma Castle NM.

\begin{tabular}{ll}
\hline Collection & Collection cont. \\
\hline Brigham Young University & North Carolina State Museum of Natural Sciences \\
\hline California Academy of Science & Oklahoma Museum of Natural History, Norman \\
\hline Chicago Academy of Sciences & Peabody Museum, Yale University \\
\hline Cincinnati Museum of Natural History \& Science & Saguaro National Park \\
\hline Cornell Vertebrate Collections, Cornell University & Strecker Museum, Baylor University, Waco \\
\hline Fort Worth Museum of Science and History & Texas Cooperative Wildlife Collection \\
\hline George Mason University (Fairfax, VA) & Tulane Museum of Natural History \\
$\begin{array}{l}\text { Illinois Natural History Survey } \\
\text { Marjorie Barrick Museum, University of Nevada-Las Vegas }\end{array}$ & U.S. National Museum \\
\hline Michigan State University Museum (East Lansing) & University of Arizona \\
\hline Milwaukee Public Museum & University of Texas, Arlington \\
\hline Museum of Comparative Zoology, Harvard University & University of Texas, El Paso \\
\hline Museum of Texas Tech University & University of Illinois, Champaign-Urbana \\
\hline Museum of Vertebrate Zoology, University of California, Berkeley & University of Michigan \\
\hline Museum of Life Sciences, Louisiana State University, Shreveport & Walnut Canyon National Monument \\
\hline \begin{tabular}{l} 
Museum of Natural History, University of Kansas \\
\hline Natural History Museum of Los Angeles County
\end{tabular} & Western Archaeological and Conservation Center, Tucson \\
\hline
\end{tabular}




\section{Chapter 2: Monument Overview}

\section{Monument Area and History}

Montezuma Castle National Monument is located in central Arizona, approximately $6 \mathrm{~km}$ northeast of the town of Camp Verde in the Verde Valley between Flagstaff and Phoenix (Figure 2.1). The monument was established in 1906 to protect Sinagua culture cliff dwellings, most notably the five-story, 20-room structure known as Montezuma Castle, perched on a limestone cliff face overlooking lower Beaver Creek. The monument consists of two separate units, the Castle and Well units, located about $8 \mathrm{~km}$ apart. The Well unit protects additional Sinagua and Hohokam sites and the large, spring-fed limestone sink (from which the site receives its name) that has no known parallel anywhere in the world in its depth, its highly carbonated waters, and its uniquely adapted endemic invertebrate community (Blinn and Oberlin 1996). Montezuma Castle NM is a relatively small monument: the Castle unit comprises 230 ha, and the Well unit is 103 ha. Montezuma Castle NM has an average annual visitation of 800,000 (NPS 2005).

\section{Natural Resources Overview}

\section{Physiography, Geology and Soils}

Montezuma Castle NM is located in the Central Highlands Province in the Verde Valley bounded by the Mogollon Rim to the north and Fossil Creek to the south. Elevation at the monument varies from $955 \mathrm{~m}$ to $1,090 \mathrm{~m}$. The Verde Valley is a down-faulted Cenozoic sedimentary basin in the transitional zone of central Arizona (Lindsay 2000). The Verde Valley is filled with Verde Formation sediment, a young lacustrine sediment with limestone, classic, and evaporitic facies (Lindsay 2000). There are two types of soils at the monument: riverine bottomland soils composed of alluvium; and upland, rocky calcareous soils composed of limestone-derived soils (Rowlands 1999). For a complete soil survey, see Lindsay (2000).

\section{Hydrology}

Beaver Creek, a tributary to the Verde River, runs through the Castle unit and its tributary, Wet Beaver Creek, runs through the Well unit. Both Beaver and Wet Beaver creeks have intermittent water flow. Montezuma Well is a large, spring-fed limestone sink measuring approximately $91 \mathrm{~m}$ by $107 \mathrm{~m}$. The main concerns about these water sources are high rates of withdrawal and non-point source pollution from urban development and agricultural and livestock runoff (Sprouse et al. 2002).

\section{Climate}

Montezuma Castle NM experiences an annual bimodal pattern of precipitation which is characterized by heavy summer (monsoon) storms brought about by moisture coming from the Gulf of Mexico, and less intense frontal systems coming from the Pacific Ocean in the winter. On average, approximately one-half of the annual precipitation falls from July through October (Table 2.1; WRCC 2005). The area's hot season occurs from May through September and maximum temperatures in July can exceed $40^{\circ} \mathrm{C}$. Winter temperatures often dip below freezing and snow is occasional. Average annual precipitation total for the monument is $33.0 \mathrm{~cm}$.

Table 2.1. Average monthly climate data for Montezuma Castle NM, 1938-2005. (Data from WRCC 2005).

\begin{tabular}{lccccccccccccr}
\hline & \multicolumn{11}{c}{ Month } & \\
\cline { 2 - 11 } Characteristic & Jan & Feb & Mar & Apr & May & Jun & Jul & Aug & Sep & Oct & Nov & Dec & Annual \\
\hline Maximum temperature $\left({ }^{\circ} \mathrm{C}\right)$ & 15.5 & 18.2 & 21.4 & 25.9 & 31.0 & 36.4 & 38.4 & 36.8 & 34.1 & 28.2 & 20.5 & 15.4 & 26.8 \\
\hline Minimum temperature $\left({ }^{\circ} \mathrm{C}\right)$ & -3.2 & -1.5 & 1.1 & 4.2 & 8.0 & 12.2 & 17.5 & 16.9 & 12.7 & 6.1 & -0.2 & -3.3 & 5.9 \\
\hline Precipitation $(\mathrm{cm})$ & 2.8 & 3.0 & 3.0 & 1.8 & 0.8 & 0.7 & 3.6 & 5.2 & 4.0 & 2.6 & 2.2 & 3.1 & 2.7 \\
\hline
\end{tabular}




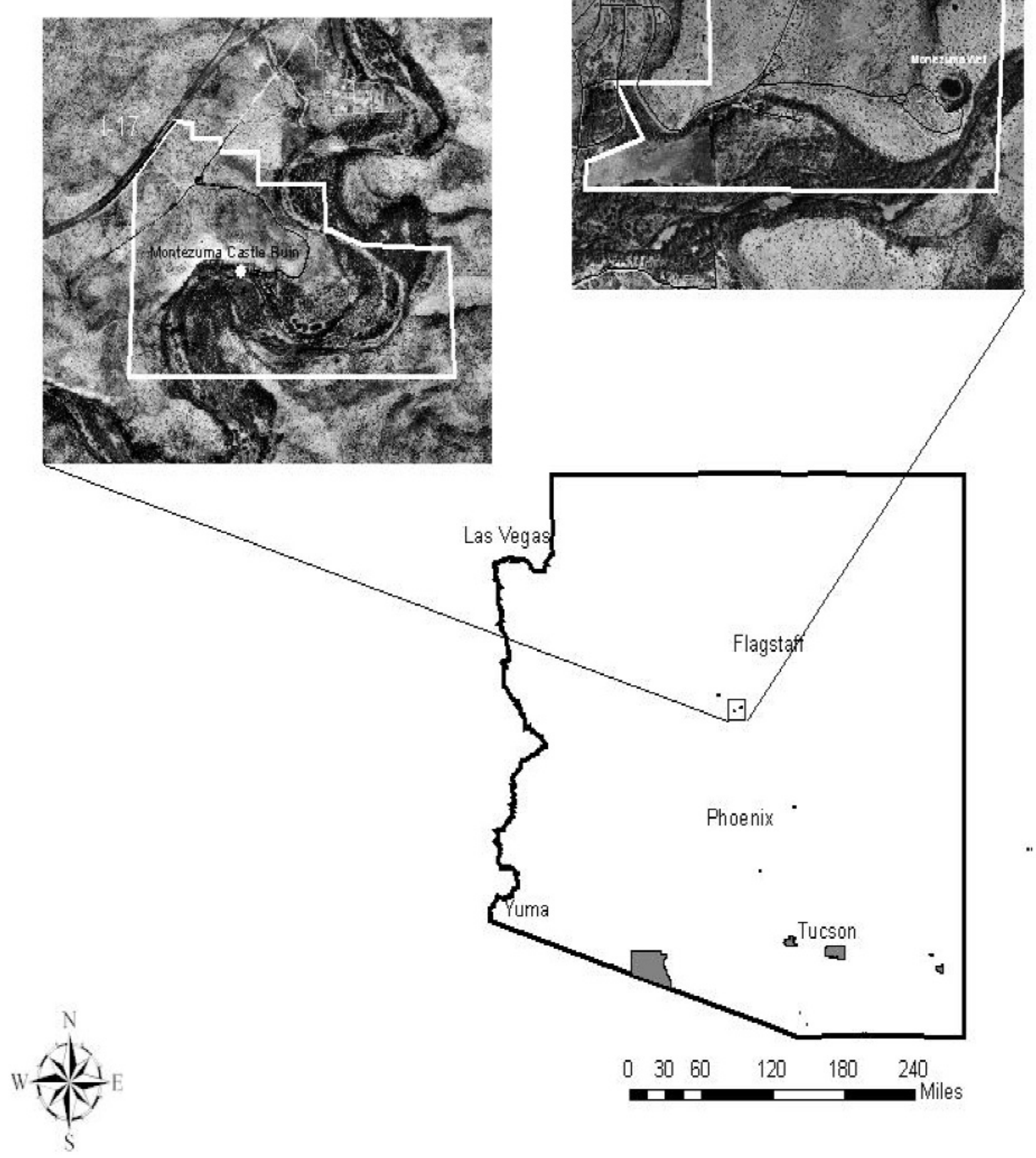

Figure 2.1. Location of Montezuma Castle NM in Arizona and aerial photographs of the Castle and Well units. 


\section{Vegetation}

Overall the monument supports scattered juniper at its higher elevations, and mesquite, acacia and creosote bush at its lower elevations. There is a rich cottonwood riparian association along Beaver Creek. According to Rowlands (1999):

The Castle unit of Montezuma Castle NM has eight biomes (after Brown et al. 1980):

- Plains grassland containing broom snakeweed-catclaw acacia-velvet mesquite association;

- Sonoran riparian and oasis forest containing velvet mesquite association;

- Sonoran savanna grassland containing threeawn-mixed-scrub association;

- Chihuahuan desertscrub containing mariola-creosote bush association;

- Sonoran desertscrub containing creosote bush-mixed scrub association, creosote bush association, and crucifixion thorn association;

- $\quad$ Southwestern riparian deciduous forest and woodland containing Arizona sycamore-green ash association.

- Scrub-grassland containing New Mexico feathergrass-mixed scrub association;

- Interior southwestern swamp and riparian scrub containing desert willow association.

The Well unit of Montezuma Castle NM also has eight biomes (after Brown et al. 1980):

- Interior chaparral containing Sonoran scrub oak-skunkbush sumac association;

- Plains grassland containing broom snakeweed-catclaw acacia association;

- Scrub-grassland containing New Mexico feathergrass-mixed scrub association;

- Chihuahuan desertscrub containing mariola-broom snakeweed association;

- Sonoran desertscrub containing crucifixion thorn association;

- $\quad$ Southwestern riparian deciduous forest and woodland containing Arizona sycamoregreen ash-Fremont cottonwood association;

- Sonoran riparian and oasis forest containing velvet mesquite association, velvet mesquite-catclaw acacia-broom snakeweed association, and fourwing saltbush-velvet mesquite association;
- $\quad$ Sonoran interior marshland containing softstem bulrush-beaked spikerush association.

\section{Natural Resource Management Issues}

\section{Adjacent Land Use and Development}

The area near the monument is experiencing rapid growth in human population and an associated increase in the number of housing developments near the monument. This creates many natural resource management challenges including the introduction of non-native species (e.g., plants used for landscaping), increased groundwater withdrawal, surface water pollution, and visual intrusions to the natural landscape.

\section{Non-native Species}

Because of the long-term anthropogenic disturbances in the area, non-native species have become an important natural resource issue (Rowlands 1999). Within the monument boundary non-native grasses such as red brome and ripgut brome have become well established. Saltcedar has also become established along the banks of Beaver and Wet Beaver creeks. In Beaver Creek nonnative fish, crayfish, and the American bullfrog are likely causing declines in abundance or even extirpation of native fishes, amphibians, and some aquatic reptiles. Other non-native vertebrate species include the European starling and house sparrow. We address many of these non-native species in each of the following chapters.

\section{Visitor Use}

Visitor use and recreational activities (e.g., hiking, fishing) at the monument and surrounding lands is high and may be problematic. Because of the high visitation to the monument, natural resources such as soil stability and vegetation may be damaged by visitors hiking off-trail. In addition, high numbers of visitors using trails may affect animal movement patterns, especially for medium-sized and large mammals and snakes. Visitors may also introduce non-native plant species by dispersing seed attached to clothing or automobiles. 


\section{Chapter 3: Plants}

There have been several vegetation surveys and plant species lists created for Montezuma Castle NM. Spangle and Sutton (1949) created the first species list for Montezuma Well based on collections made between March and November 1948. McDougall and Haskell (1960) created a key for plants occurring at both the Castle and Well units. Clark and Burgess (1966) studied species composition of perennial vegetation on the rim of Montezuma Well. An inventory of riparian trees at the Castle unit was completed by Reichenbacher (1990). A complete inventory of all plants in both units was completed by Jenkins et al. (1991). In 1994, Brian and Rowlands published an annotated vascular plant species list for the monument based on previous research and collections. Rowlands (1999) completed vegetation mapping and classification of both units. Halvorson and Guertin (2003) and Mau-Crimmins et al. (2004) mapped distribution of non-native plants at both units of the monument. Finally, the NPS Sonoran Desert Network (SDN) Inventory and Monitoring Network (unpublished data) conducted modular plot and transect vegetation surveys at both units of the monument.

A historical photograph survey was conducted by Richmond (1995), who found 103 photographs taken at the monument dating as far back as 1876 . These photographs may serve as a historical review of vegetation changes at the monument.

\section{Data Used to Create Plant Species List}

The plant species lists for both units of the monument (Appendices A and B) are based on Brian and Rowlands (1994), Rowlands (1999), Halvorson and Guertin (2003), Mau-Crimmins et al. (2004), and the NPS SDN Inventory and Monitoring data (unpublished). Taken together, these lists represent a comprehensive list of the plants occurring at the monument.

\section{Peebles' bluestar}

In Brian and Rowlands (1994), wooly bluestar (Amsonia tomentosa) was included in their species list. We have changed this species to Peebles' bluestar (Amsonia peeblesii) based on information provided by Peter Rowlands that wooly bluestar was a misidentification. Glenn Rink, a botanist at Northern Arizona University, also checked the specimen and confirmed the proper identification of the plant was Peebles' bluestar.

\section{Results and Discussion}

There have been 404 species of plants documented or recorded at the Castle unit; of these, $57(14 \%)$ were non-native (Appendix A). There have been 338 species of plants documented or recorded at the Well unit; of these, $61(18 \%)$ are non-native (Appendix B). In all, there have been 472 species of plants documented or recorded at both units of the monument (Appendix A and B); of these, 72 $(15 \%)$ are non-native. The percentage of nonnative plant species recorded in the monument is slightly lower than the percentage of non-native plants recorded at nearby Tuzigoot National Monument (Schmidt et al. 2005) which is also located in the Verde Valley. This percentage is relatively high compared to non-native plant species in other park units in the Sonoran Desert Network. One reason for the high number of nonnative plant species is that the monument has undergone extensive disturbance since prehistoric times. Ancient Hohokam peoples and European settlers practiced agriculture and grazed cattle in the area (Rowlands 1999). Many of the non-native plant species that have invaded the monument are grasses, which have created an unnatural fire hazard (Rowlands 1999). According to Halvorson and Guertin (2003) and Mau-Crimmins et al. (2004) there are several non-native species that are widespread, including London rocket, redstem stork's bill, red brome, cheatgrass, and ripgut brome. Rowlands (1999) found that the southeastern portion of the Well unit was the most disturbed area and the southeastern corner of the Castle unit was one of the areas least disturbed and in the most natural state.

Another worrisome occurrence is the apparent decline of mesquite bosque along Beaver Creek possibly due to the increase of groundwater pumping leading to lower groundwater levels (Rowlands 1999). 


\section{Inventory Completeness}

The plant inventory for Montezuma Castle NM is considered to be complete due to the extensive studies conducted over more than five decades. However, new species, especially non-native species, will most likely continue to become established. 


\section{Chapter 4: Fishes}

The most thorough fish surveys conducted on the sections of Beaver and Wet Beaver creeks within the monument were by Montgomery et al. (1995, 1996) from 1992 to 1994 . They used electrofishing, trammel nets, and seining to collect fish.

Montgomery et al. (1995) also summarized the findings of incidental collections that were taken near the monument during the 1930s, 1960s and 1970s and an unpublished survey by the Arizona Game and Fish Department that was conducted in the 1980 s.

\section{Data Used to Create Fish Species List}

The fish species list for the monument (Appendix C) is based on the findings of Montgomery et al. (1995, 1996).

\section{Results and Discussion}

Montgomery et al. $(1995,1996)$ documented nine species of fishes, including five non-natives (Appendix C). All four of the native species documented are federally listed Species of Concern. Over the last 60 years, a major shift in the fish community of Beaver Creek has occurred, from an assemblage of native species to a community dominated by introduced non-native species, though a few native species persist in low to moderate numbers. The decline in native fish species is most likely due to predation and competition by non-native species and changes in water flow caused by human usage (Montgomery et al. 1995). High flood flows along Beaver Creek in the summer appear to temporarily reduce the number of introduced species and allow the native species to temporarily increase in numbers (Montgomery et al. 1995).

\section{Inventory Completeness}

The list of nine species from Montgomery et al. $(1995,1996)$ is considered to be complete. There are several species that may occur or have occurred in the past at the monument (Appendix G). The native fish - speckled dace, spikedace, and loach minnow - are now restricted to the Gila River system and have not been documented in Beaver Creek since the late 1930s (Montgomery et al. 1995). Spotted bass, largemouth bass, black bullhead and channel catfish were introduced in the area for sport fishing, but have not been documented in the area since the 1960s and 70s (Montgomery et al. 1995). 


\section{Chapter 5: Amphibians and Reptiles}

The only known amphibian and reptile inventory was conducted at Montezuma Castle NM by Drost and Nowak (1998) from 1993 to 1994 . They used pitfall traps, coverboards, funnel traps, and visual searches to record or document amphibians and reptiles at the monument. They also searched museum collections for voucher specimens. A study was conducted by Windes et al. (1997) that inventoried amphibians and reptiles of the Beaver Creek Wilderness; however, their study yielded no additional species than those recorded by Drost and Nowak (1998). A study was also conducted on the effects of relocations of rattlesnakes at the monument from 1994-1996 (Nowak and van Riper III 1999), and research is currently being conducted on the ecology of nuisance rattlesnakes and their prey by Erika Nowak. Nowak has also been collecting incidental observations of amphibians and reptiles since the completion of the inventory in 1996. A complete inventory was conducted at Tuzigoot NM which is located nearby in the Verde Valley (Schmidt et al. 2005).

\section{Data Used to Create Amphibian and Reptile Species List}

The amphibian and reptile species list for the monument (Appendix D) is based on Drost and Nowak (1998) and additional personal observations by Paul Super (NPS employee) and monument personnel.

\section{Results and Discussion}

There have been 34 species of amphibians and reptiles found at the monument, of which three are non-native (Appendix D). Amphibian diversity at the monument is low, consisting of two toads, one treefrog, and the introduced American bullfrog. The American bullfrog is apparently a recent arrival (it was not vouchered at the monument prior to the Drost and Nowak [1998] study) and was only found in low numbers (Drost and Nowak 1998). The lizard community at the monument is one of the most species rich (13 species) in the Sonoran Desert Network of park units. The population of Sonoran mud turtles at Montezuma
Well is also noteworthy for its very high density (Drost and Nowak 1998).

Although comprehensive historical survey data are not available for comparison, museum records show that lowland leopard frogs (which have declined throughout the southwest) once occurred in the vicinity of the monument but were not documented by Drost and Nowak (1998) and are believed to no longer occur in the area. Gila monsters also formerly occurred at the monument, but were not found by Drost and Nowak (1998). The Arizona toad is another species that may be extirpated from the monument. There are no specimen records to document its former occurrence at Montezuma Castle NM, but it formerly occurred in the area; appropriate habitat is present at the monument but none were found by Drost and Nowak (1998). Loss and decline of many species may be due to the loss of desert grasslands, invasion of non-native plant species, and changes in aquatic habitats (such as water flow and quality; Drost and Nowak 1998).

\section{Inventory Completeness}

Drost and Nowak (1998) conducted a relatively thorough inventory of the monument and Nowak (unpublished data) has continued to collect observational data on amphibians and reptiles at Montezuma Castle NM. Nowak has not, to date, detected any new species and she estimates that inventory completeness at the monument is at least 90-95\%.

\section{Possible Species}

Here we identify species that have not been confirmed to occur at the monument (Appendix $\mathrm{H}$ ), but that may occur there based on documentation from nearby Tuzigoot NM by Schmidt et al. (2005) and based on habitat and range (Drost and Nowak 1998).

\section{Greater short-horned lizard}

The greater short-horned lizard was documented by Drost and Nowak (1998) about a half mile southwest of the Well unit. 


\section{Snakes}

There are six snake species that may occur at the monument. Five of these species (western blind snake, Sonoran whipsnake, Mexican garter snake, southwestern black-headed snake and western lyre snake) have been documented in the Verde Valley at Tuzigoot NM (Schmidt et al. 2005) and two (Sonoran whipsnake and western lyre snake) were found near the Well unit (Drost and Nowak 1998). One other species of snake that may occur at the monument (Mojave rattlesnake), occurs in the Verde Valley and if found at the monument would most likely occur at the Well unit. 


\section{Chapter 6: Birds}

Several bird species lists have been created for Montezuma Castle NM and the surrounding area. The first was created by Jackson (1941) based on observations she made at the monument from 1936 to 1940. A compilation of bird observations at the monument was created by Frost (1947), and included the observations by Jackson (1941), as well as others. Another compilation was created by Sutton (1954) that included all past bird observations made in the entire Verde Valley. From 1973 to 1980 the National Audubon Society (No date) conducted Christmas bird counts near the monument. More recently, Sogge and Johnson (1998) conducted point counts and transect surveys at Montezuma Castle NM from 1991 to 1994. The list created by Sogge and Johnson (1998) was recently updated by Sogge et al. (In press). A comprehensive survey that took place from 2003 to 2004 at nearby Tuzigoot NM located in the Verde Valley, including point counts and transect surveys, was summarized by Schmidt et al. (2005). Finally, a study on yellow-billed cuckoos at the monument has just been completed by Matt Johnson.

\section{Data Used to Create Bird Species List}

The bird species list for the monument (Appendix E) is based solely on Sogge et al. (In press).

\section{Results and Discussion}

There have been 211 species of birds found at the monument (Appendix E), of which four are nonnative and 41 species require open water (found at Montezuma Well): 22 species of ducks and geese (Anatidae), one grebe (Podicipedidae), four species of heron and egret (Ardeidae), four species of rail (Rallidae), seven species of "shorebirds" (Charadriidae and Scolopacidae), and three other species.
Based on the list created by Sogge et al. (In press), the bird community at Montezuma Castle NM is among the most species rich for park units in the Sonoran Desert Network. This high species richness is extraordinary for a park unit of its size, and Beaver and Wet Beaver creeks and Montezuma Well are the resources that account for this. The riparian areas adjacent to the creeks support a high number of riparian obligate birds such as summer tanager, song sparrow, Abert's towhee, yellow warbler, yellow-breasted chat, and sensitive species (Arizona State Wildlife Species of Concern) including nesting common black-hawks, belted kingfishers, and yellow-billed cuckoos (also a candidate for listing under the Endangered Species Act). The dense stands of cottonwood and willow trees provide vital habitat for these species, yet these areas are rare in the southwest (Ohmart 1994). Research in the southwestern U.S. has consistently shown that areas with riparian trees have bird communities that are more diverse than adjacent sites (Carothers et al. 1974, Szaro and Jakle 1985, Strong and Bock 1990). This is due, in part, to the variety of microhabitats that riparian vegetation provides for nesting (Powell and Steidl 2000), cover, and foraging.

\section{Inventory Completeness}

The bird list for Montezuma Castle NM is near completion. We include a list of species that have been observed elsewhere in the Verde Valley that may also be present at the monument (Appendix I). Many of these species may be present only as flyovers (flying over the monument) en route to large open areas of water (i.e. Montezuma Lake), especially many of the "shorebirds" (families Scolopacidae and Recurvirostridae) and gulls (family Laridae). 


\section{Chapter 7: Mammals}

The first known work conducted on mammals in the area was by Walter P. Taylor and Hartley H. T. Jackson in 1916 (Drost and Ellison 1996). Taylor and Jackson's research included interviewing local residents about their observations. More recently, Ellison and van Riper III (1996) studied small mammal community patterns in riparian floodplain and mesquite habitats. Drost and Ellison (1996) conducted a thorough inventory of all mammals, which included pitfall trapping for shrews, mist netting for bats, trapping for small and mediumsized mammals, visual surveys for large and aquatic mammals, Trailmaster camera stations, and track and sign surveys. Drost and Ellison (1996) also compared their results with results from Taylor and Jackson. In 2002 and 2003, Bucci and Petryszyn (2004) conducted mist netting and acoustic surveys for bats at the monument. In addition, Erika Nowak has been trapping small mammals at the Castle unit since 2003 in conjunction with a study of nuisance rattlesnake ecology.

\section{Data Used to Create Mammal Species List}

The mammal species list for the monument (Appendix F) is based on the documentations made by Drost and Ellison (1996) and Bucci and Petryszyn (2004).

\section{Results and Discussion}

There have been 58 species of mammal documented at the monument: 18 bats, 15 small terrestrial mammals (primarily rodents), and 25 medium to large mammals (Appendix F). Of the 58 species documented, only one was non-native. One reason for the monument's high number of mammal species may be its location near the northern edge of the Sonoran Desert and the southern edge of the Mogollon Rim. Many species from both ecosystems have been, or may be, found there. Several of the species documented by Drost and Ellison (1996) (cactus mouse, Piñon mouse, Stephens's woodrat and Harris' antelope squirrel) are at the edge of their geographic ranges. In addition, two species that may be present would be at the edge of their geographic ranges (long-legged myotis and southern grasshopper mouse).

Beaver and Wet Beaver creeks and Montezuma Well provide a constant source of water for several mammals that are rare in Arizona: American beaver, muskrat, and river otter. The American beaver and river otter were trapped historically for their dense fur. In the early $1900 \mathrm{~s}$ the American beaver population had declined and the southwestern subspecies of the river otter (Lontra canadensis sonora) was nearly, or possibly, trapped to extinction. Because habitats, in Arizona where the American beaver, muskrat and river otter occurred historically, have been altered due to dams, diversions, and other forms of habitat alteration, the monument (including Montezuma Well and the sections of Beaver and Wet Beaver creeks) appears to be important to the persistence of these species in Arizona.

The cliffs above Montezuma Well and along Beaver Creek, including the Castle itself, provide roosts for many cave and cliff bats. One species of bat that has been found to use these areas, the Townsend's big-eared bat, is a federally listed Species of Concern.

\section{Inventory Completeness}

The mammal list for Montezuma Castle NM is near completion. We believe all common and resident mammals have been documented; however, there are a few additional species that may occur at the monument (Appendix $\mathrm{J}$ ) based on Drost and Ellison (1996).

\section{Long-legged myotis and silver-haired bat}

Both of these species have been documented in the Verde Valley and their ranges include the monument (Hoffmeister 1986), however, they have never been documented at the monument.

\section{Western bonneted bat}

This bat ranges widely throughout Arizona. It roosts in shallow caves and cliffs which are present at the monument; however this species has not been documented in the Verde Valley. 


\section{White-nosed coati}

This species usually inhabits oak woodland in the southeastern portion of Arizona, however

"stragglers and wanderers" may be found further north (Hoffmeister 1986).

\section{Western spotted and hooded skunks}

Both species have been documented in the Verde Valley. Western spotted skunks are uncommon throughout their range and the hooded skunk is uncommon through the northern part of its range. It is likely that the western spotted skunk is currently present or will be found in the future at the monument.

\section{Golden-mantled ground squirrel}

This species is common along the Mogollon Rim and, if found at the monument, it would be at the southernmost extent of its range.

\section{Arizona pocket mouse and southern grasshopper mouse}

Usually found in Mohave and Sonoran desertscrub, these species have been documented in the Verde Valley (Hoffmeister 1986). If found at the monument they would be at the northernmost part of their ranges.

\section{Hispid pocket mouse}

An isolated population of this species was documented in the Verde Valley (Hoffmeister 1986), but is believed to no longer occur in the area.

\section{Plains harvest mouse}

This wide-ranging species has been documented in the Verde Valley by Hoffmeister (1986). He found geographic overlap between this and the western harvest mouse, which was captured by Drost and Ellison (1996) at Montezuma Castle NM.

\section{House mouse}

The house mouse was previously documented at the monument by Taylor and Jackson (Drost and Ellison 1996), however, recently none have been found at the monument. This species is closely associated with human development and as developments continue to increase near the monument this species may once again occur at the monument.

\section{Species No Longer Present}

There are two species that are believed to no longer be present at the monument; however, it may be premature to say that these species have been extirpated from the Verde Valley: Gunnison's prairie dog (Cynomys gunnisoni) and pronghorn (Antilocapra americana).

Grizzly Bear, Ocelot, Jaguar and Mexican Gray Wolf

Four species have been extirpated from the Verde Valley: grizzly bear (Ursus arctos), ocelot (Leopardus pardalis), jaguar (Panthera onca) and Mexican gray wolf (Canis lupus baileyi). The last grizzly bear in Arizona is believed to have been killed in the mid 1920s (Hoffmeister 1986). The range of both the ocelot and jaguar has shrunk substantially. Currently they occur very rarely in Arizona and only in the extreme south and southeast portion of the state. The Mexican gray wolf was extirpated from Arizona, however, beginning in the 1990s they were reintroduced into central eastern Arizona. It is unlikely that this species will occur again at the monument because of urban development surrounding both the Castle and Well units. 


\section{Chapter 8: Management Implications}

Based on data from previous studies and our knowledge of the natural resource issues at the monument, herein we address issues that affect management of the monument's natural resources.

\section{Adjacent Land Development and Water}

As the Verde Valley becomes increasingly developed, undisturbed areas will become scarce and likely restricted to inaccessible terrain. It is important to maintain the present, relatively undisturbed state of the southeast portion of the Castle unit by eliminating trespass grazing and other incompatible uses.

Water rights adjudication will be important to the future of water quality and quantity flowing through the monument. The seasonal pattern of flooding and drying may be important to maintaining native fish populations according to Montegomery et al. (1995). Communication with other agencies involved with water use and water resources in the Beaver Creek/Verde River drainage will help to maintain instream flows at the monument. Maintaining healthy riparian communities and aquatic habitats is particularly important for amphibians who are dependent on these communities. Measures to protect stream flow, water quality, the natural hydrologic regime, and native aquatic species (e.g., restoring native fish species) will benefit amphibians.

\section{Non-native Species and Grasslands}

Mediterranean grasses and other exotic plants create seasonally high levels of fire fuels that increase to a maximum standing crop during the summer months when lighting strikes are most likely. An integrated approach to vegetation management in the bottomlands utilizing all feasible aspects of weed control, including (where appropriate) chemical control and prescribed fire, would help maintain a natural system. Mechanical control of the annual weedy growth at the Well unit could actually encourage the spread of weedy exotic plants by repeated disturbance of the substrate, abetting the seed dissemination of exotic weeds and retarding the natural invasion of native species, such as mesquite and acacia. Young specimens of the latter are repeatedly mowed down soon after establishment.

Some of the species declines that have occurred at the monument (including the Gila monster, Arizona cotton rat, and hispid pocket mouse) seem to be related to the decline and loss of desert grassland habitat. Unfortunately, we do not have detailed information on past habitat composition and structure at the monument, but restoration of native grassland habitats and native species in general (and reduction of non-natives such as red brome) would be beneficial.

\section{Bats}

Disturbances to breeding Townsend's big-eared bats at the Montezuma Well Swallet Cave should be avoided. Townsend's big-eared bat is a federal Species of Concern and is considered sensitive to disturbance at roost caves (Bucci and Petryszyn 2004). Any access to the cave at Montezuma Well should be timed to avoid the period when the bats have young (April through July). 


\section{Chapter 9: Additional Inventories and Research}

No inventory is ever truly complete; species distributions expand and contract across

boundaries, particularly in small park units such as Montezuma Castle NM. We recommend a complete inventory be conducted again in approximately 10 years to detect any changes in species status.

\section{Fish}

To help understand the native fish community in Beaver Creek further research is recommended including: 1) continued fish species composition and abundance monitoring, particularly in relation to flood events and periods of stream drawdown and; 2) marking native suckers to monitor age, growth rate, and movements. Monitoring and research should be coordinated with Arizona Game and Fish Department, USDA Forest Service, or other agencies working in this section of the Verde River drainage.

\section{Amphibians and Reptiles}

Amphibian populations in much of the western United States have experienced serious declines. The cause of many of the declines is not known, and part of the reason for this is that we do not have good baseline information on amphibian populations. Given the extensive inventory work at the monument, this area would be a valuable site for continuing to collect information on population trends. 


\section{Chapter 10: Literature Cited}

American Ornithologists' Union (AOU). 1998. Checklist of North American birds, seventh edition. American Ornithologists' Union and Allen Press Inc., Lawrence, KS.

American Ornithologists' Union (AOU). 2003. Fortysecond supplement to the American Ornithologists' Union checklist of North American birds. Auk 117:847-858.

Baker, R. J., L. C. Bradley, R. D. Bradley, J. W. Dragoo, M. D. Engstrom, R. S. Hoffmann, C. A. Jones, F. Reid, D. W. Rice, and C. Jones. 2003. Revised checklist of North American mammals north of Mexico, 2003. Occasional Papers of the Museum of Texas Tech University 229:1-23.

Blinn, D., and G. E. Oberlin. 1996. Aquatic biota: invertebrates and algae. U.S. Geological Survey, Colorado Plateau Research Station, Flagstaff, AZ.

Brian, N. J., and P. G. Rowlands. 1994. An annotated vascular plant species list for Montezuma Castle and Montezuma Well National Monuments, Arizona. U.S. Geological Survey, Colorado Plateau Research Station, Flagstaff, AZ.

Brown, D. E., C. H. Lowe, and C. P. Pase. 1980. A digitized systematic classification for ecosystems with an illustrated summary of the natural vegetation of North America. General Technical Report RM-73, USDA Forest Service, Fort Collins, CO.

Bucci, M., and Y. Petryszyn. 2004. Bat use of Montezuma Castle National Monument, Tonto National Monument, and Tuzigoot National Monument, Arizona. Report to Montezuma Castle National Monument, Camp Verde, AZ.

Carothers, S. W., R. R. Johnson, and S. W. Aitchison. 1974. Population structure and social organization of Southwestern riparian birds. American Zoologist 14:97-108.

Clark, A., and R. L. Burgess. 1966. The persistent perennial vegetation on the rim of Montezuma Well, Arizona. Journal of the Arizona Academy of Science 4: 35-42.

Drost, C. A., and L. E. Ellison. 1996. Inventory and assessment of mammal communities in Montezuma Castle National Monument. U.S. Geological Survey, Colorado Plateau Field Station, Flagstaff, AZ.

Drost, C. A., and E. M. Nowak. 1998. Inventory and assessment of amphibian and reptile communities at Montezuma Castle National Monument. U.S. Geological Survey, Colorado Plateau Field Station, Flagstaff, AZ.
Ellison, L. E., and C. van Riper III. 1996. A comparison of small mammal communities at Montezuma Castle National Monument. National Park Service Technical Report NPS/NAUMOCA/NRTR-96/11.

Frost, C. B. 1947. A check list of birds recorded in the Montezuma Castle Area. Unpublished list to Montezuma Castle National Monument, Camp Verde, AZ.

Halvorson, W. L., and P. Guertin. 2003. USGS Weeds in the West project: status of introduced plants in southern Arizona parks. U.S. Geological Survey, Southwest Biological Science Center, Sonoran Desert Research Station, University of Arizona, Tucson, AZ.

Heritage Data Management System (HDMS). 2004. Arizona Game and Fish Department. Accessed 5 March from: http://www.gf.state.az.us/w_c/edits/ hdms_species_lists.html.

Hoffmeister, D. F. 1986. Mammals of Arizona. The University of Arizona Press, Tucson, AZ.

Integrated Taxonomic Information System (ITIS). 2004. Accessed on 20 March 2004. http://www.itis.usda.gov/index.html.

Jackson, B. 1941. Birds of Montezuma Castle. Southwestern National Monuments Special Report No. 28.

Jenkins, P., F. Reichenbacher, K. Johnson, A. Gondor. 1991. Vegetation inventory, classification, and monitoring for Montezuma Well, Montezuma Castle National Monument. Southwestern Field Biologists, Tucson, AZ.

Latta, M. J., C. J. Beardmore, and T. E. Corman. 1999. Arizona Partners in Flight conservation plan. Technical Report 142. Nongame and Endangered Wildlife Program, Arizona Game and Fish Department, Phoenix, AZ.

Lindsay, B. A. 2000. Soil survey of Montezuma Castle National Monument, Arizona (including Montezuma Well). U.S. Geological Survey, Sonoran Desert Field Station, University of Arizona, Tucson, AZ.

Mau-Crimmins, T., A. Hubbard, and G. R. McPherson. 2004. Non-native plant mapping at Montezuma Castle and Tuzigoot National Monuments. National Park Service, Sonoran Desert Inventory and Monitoring Program, Tucson, AZ.

McDougall, W. B., and H. S. Haskell. 1960. Seed Plants of Montezuma Castle National Monument. Museum of Northern Arizona Bulletin 35. 
Montgomery, W. L., G. G. Hardwick, and J. White. 1996. Montezuma Castle National Monument: fish monitoring. Report to Montezuma Castle National Monument, Camp Verde, AZ.

Montgomery, W. L., W. C. Leibfried, and G. G. Hardwick. 1995. Beaver Creek aquatic study for Montezuma Castle National Monument: fish and herpetofauna. Final Report to Montezuma Castle National Monument, Camp Verde, AZ.

National Audubon Society. No date. Christmas bird count data. Accessed November 7, 2005 from: http://www.audubon.org/bird/cbc/hr/index.html.

National Park Service (NPS). 1992. NPS-75: Natural resources inventory and monitoring guidelines. U.S. Dept. of Interior, Washington, D.C.

National Park Service (NPS). 2005. NPS Visitation Database Reports. Accessed October 22, 2005 from: http:/www2.nature.nps.gov/NPstats/ npstats.cfm.

Nowak, E., and C. van Riper III. 1999. Effects and effectiveness of rattlesnake relocation at Montezuma Castle National Monument. Technical Report Series USGSFRESC/COPL/1999/17, USGS Colorado Plateau Field Station, Flagstaff, AZ.

Ohmart, R. D. 1994. The effects of human-induced changes on the avifauna of western riparian habitats. Studies in Avian Biology 15:272-285.

Powell, B. F., and R. J. Steidl. 2000. Nesting habitat and reproductive success of southwestern riparian birds. Condor 102:823-831.

Rappole, J. H. 1995. The ecology of migrant birds: a neotropical perspective. Smithsonian Institution Press, Washington, D.C.

Reichenbacher, F. W. 1990. Inventory of riparian trees at Montezuma Castle, Montezuma Castle National Monument, Arizona. F. W. Reichenbacher \& Associates, Tucson, AZ.

Richmond, A. J. 1995. Historic photograph survey Montezuma Castle/Well National Monument 1879-1990. Technical Report NPS/NAUMOCA/NRTR-95/08. U.S. Geological Survey, Colorado Plateau Research Station, Flagstaff, AZ.

Rowlands, P. G. 1999. Vegetation survey of Montezuma Castle National Monument. Unpublished report to Montezuma Castle National Monument, Camp Verde, AZ.

Schmidt, C. A., B. F. Powell, and W. L. Halvorson. 2005. Vascular plant and vertebrate inventory of Tuzigoot National Monument. Final report to the National Park Service, Sonoran Desert Inventory and Monitoring Program, Tucson, AZ.
Sogge, M. K., and M. J. Johnson. 1998. Montezuma Castle Avian Inventory 1991-1994. Final Project Report to Montezuma Castle National Monument, Camp Verde, AZ.

Sogge, M. K., M. J. Johnson, and C. van Riper III. In press. The birds of Montezuma Castle National Monument, AZ. U.S. Geological Survey, Colorado Plateau Research Station, Flagstaff, AZ.

Spangle, P., and M. Sutton. 1949. The botany of Montezuma Well. Plateau 22:11-19.

Sprouse, T., R. Emanuel, and B. Tellman. 2002. Surface water quality monitoring overview and assessment. Unpublished report to the National Park Service, Sonoran Desert Network Inventory and Monitoring Program, Tucson, AZ.

Stebbins, R. C. 2003. A field guide to western reptiles and amphibians. Third edition. Houghton Mifflin, New York, NY.

Stohlgren, T. J., J. F. Quinn, M. Ruggiero, and G. S. Waggoner. 1995. Status of biotic inventories in U.S. national parks. Biological Conservation 71:97-106.

Strong, T. R., and C. E. Bock. 1990. Bird species distribution patterns in riparian habitats in southeastern Arizona. Condor 92:511-519.

Sutton, M. 1954. Birds of the Verde Valley. National Park Service, Montezuma Castle National Monument, Camp Verde, AZ.

Szaro, R. C., and M. D. Jakle. 1985. Avian use of a desert riparian island and its adjacent scrub habitat. Condor 87:511-519.

United States Department of Agriculture (USDA). 2004. The PLANTS Database, Version 3.5. Accessed from: http://plants.usda.gov. National Plant Data Center, Natural Resources Conservation Service, Baton Rouge, LA.

United States Fish and Wildlife Service (USFWS). 2002. Birds of conservation concern 2002. Division of Bird Management, Arlington, VA.

Western Regional Climate Center (WRCC). 2005. Arizona climate summaries from Montezuma Castle National Monument, Arizona. Accessed October 22, 2005 from: http://www.wrcc.dri.edu/ summary/climsmaz.html.

Windes, J. D., M. J. Sredl, J. E. Wallace, and B. L. Christman. 1997. Wet Beaver Creek Wilderness herpetofauna inventory. Technical Report 107. Arizona Game and Fish Department, Nongame and Endangered Wildlife. 
Appendix A. Plant species observed or collected at Montezuma Castle NM, Castle unit. Based on Brian and Rowlands (B\&R; 1994), Rowlands (Row; 1999), Halvorson and Guertin (H\&G; 2003), Mau-Crimmins et al. (Mau; 2004), and NPS (unpublished data). Species in bold-faced type are non-native.

\begin{tabular}{|c|c|c|c|c|c|c|c|}
\hline Family & Scientific name & Common name & $B \& R$ & Row & $H \& G$ & Mau & NPS \\
\hline \multirow[t]{3}{*}{ Aceraceae } & Acer negundo L. & boxelder & & $\mathrm{x}$ & & & \\
\hline & Acer negundo var. californicum (Torr. \& & & & & & & \\
\hline & Gray) Sarg. & California boxelder & $\mathrm{x}$ & & & & \\
\hline \multirow[t]{5}{*}{ Agavaceae } & Agave parryi Engelm. var. parryi & Parry's agave & $\mathrm{x}$ & & & & \\
\hline & Yucca baccata Torr. var. baccata & banana yucca & $\mathrm{x}$ & & & & \\
\hline & Yucca elata (Engelm.) Engelm. & soaptree yucca & & $\mathrm{X}$ & & & $x$ \\
\hline & Yucca elata var. verdiensis (McKelvey) & & & & & & \\
\hline & Reveal & Verdi yucca & $\mathrm{x}$ & & & & \\
\hline Amaranthaceae & Amaranthus powellii S. Wats. & Powell's amaranth & $\mathrm{x}$ & & & & \\
\hline \multirow[t]{5}{*}{ Anacardiaceae } & Rhus aromatica Ait. & fragrant sumac & & & & & $\mathrm{x}$ \\
\hline & Rhus trilobata Nutt. & skunkbush sumac & $\mathrm{x}$ & $\mathrm{x}$ & & & \\
\hline & Rhus trilobata var. trilobata Nutt. & skunkbush sumac & & & & & $\mathrm{x}$ \\
\hline & Toxicodendron rydbergii (Small ex Rydb.) & & & & & & \\
\hline & Greene & western poison ivy & $x$ & & & & \\
\hline \multirow[t]{7}{*}{ Apiaceae } & Berula erecta (Huds.) Coville & cutleaf waterparsnip & $\mathrm{x}$ & & & & \\
\hline & Cymopterus multinervatus (Coult. \& Rose) & & & & & & \\
\hline & Tidestrom & purplenerve springparsley & $\mathrm{x}$ & & & & $\mathrm{x}$ \\
\hline & Cymopterus purpurascens (Gray) M.E. & & & & & & \\
\hline & Jones & widewing springparsley & $x$ & & & & \\
\hline & Daucus pusillus Michx. & American wild carrot & $\mathrm{x}$ & $\mathrm{x}$ & & & $\mathrm{x}$ \\
\hline & Hydrocotyle verticillata Thunb. & whorled marshpennywort & $x$ & & & & \\
\hline \multirow[t]{2}{*}{ Apocynaceae } & Amsonia peeblesii Woods. & Peebles' bluestar & $\mathrm{x}$ & & & & \\
\hline & Vinca major $\mathrm{L}$. & bigleaf periwinkle & $\mathbf{x}$ & $\mathrm{x}$ & & & \\
\hline \multirow[t]{5}{*}{ Asclepiadaceae } & $\begin{array}{l}\text { Asclepias asperula ssp. capricornu } \\
\text { (Woods.) Woods. }\end{array}$ & antelopehorns & $x$ & & & & \\
\hline & Asclepias engelmanniana Woods. & Engelmann's milkweed & $\mathrm{x}$ & & & & \\
\hline & Asclepias subverticillata (Gray) Vail & horsetail milkweed & $\mathrm{x}$ & $\mathrm{x}$ & & & \\
\hline & Funastrum cynanchoides ssp. cynanchoides & & & & & & \\
\hline & $\begin{array}{l}\text { (Dcne.) Schlechter } \\
\text { Acourtia wrightii (Gray) Reveal \& King }\end{array}$ & $\begin{array}{l}\text { fringed twinevine } \\
\text { brownfoot }\end{array}$ & $\frac{x}{x}$ & $\frac{x}{x}$ & & & $x$ \\
\hline \multirow{15}{*}{ Asteraceae } & Agoseris glauca var. laciniata (D.C. Eat.) & & & & & & \\
\hline & Smiley & false agoseris & $\mathrm{x}$ & & & & \\
\hline & Ambrosia confertiflora DC. & weakleaf burr ragweed & $\mathrm{x}$ & & & & \\
\hline & Ambrosia psilostachya DC. & Cuman ragweed & $\mathrm{x}$ & & & & \\
\hline & Artemisia Iudoviciana Nutt. & white sagebrush & $\mathrm{x}$ & $\mathrm{x}$ & & & $x$ \\
\hline & Aster L. & aster & & & & & $\mathrm{x}$ \\
\hline & Baccharis emoryi Gray & Emory's baccharis & $\mathrm{x}$ & & & & \\
\hline & Baccharis pteronioides DC. & yerba de pasmo & & & & & $\mathrm{x}$ \\
\hline & Baccharis salicifolia (Ruiz \& Pavón) Pers. & mule's fat & $\mathrm{x}$ & $\mathrm{x}$ & & & \\
\hline & Baccharis sarothroides Gray & desertbroom & $x$ & $\mathrm{X}$ & & & \\
\hline & Baccharis wrightii Gray & Wright's baccharis & $\mathrm{x}$ & & & & \\
\hline & Baileya multiradiata Harvey \& Gray ex Gray & desert marigold & $x$ & $\mathrm{x}$ & & & \\
\hline & Brickellia atractyloides Gray & spearleaf brickellbush & $\mathrm{x}$ & $\mathrm{x}$ & & & $\mathrm{x}$ \\
\hline & Brickellia californica (Torr. \& Gray) Gray & California brickellbush & $x$ & $\mathrm{x}$ & & & \\
\hline & $\begin{array}{l}\text { Brickellia eupatorioides var. chlorolepis } \\
\text { (Woot. \& Standl.) B.L. Turner }\end{array}$ & false boneset & $\mathrm{x}$ & & & & \\
\hline
\end{tabular}




\begin{tabular}{|c|c|c|c|c|c|c|c|}
\hline Family & Scientific name & Common name & B\&R & Row & $H \& G$ & Mau & NPS \\
\hline \multirow[t]{47}{*}{ Asteraceae } & Brickellia microphylla var. watsonii (B.L. & & & & & & \\
\hline & Robins.) Welsh & Watson's brickellbush & & $\mathrm{X}$ & & & \\
\hline & Centaurea melitensis $\mathrm{L}$. & Maltese star-thistle & $\mathrm{x}$ & $\mathrm{x}$ & $\mathrm{x}$ & $\mathrm{X}$ & \\
\hline & Chaetopappa ericoides (Torr.) Nesom & rose heath & $x$ & $x$ & & & $\mathrm{X}$ \\
\hline & Cichorium intybus $\mathrm{L}$. & chicory & $\mathrm{x}$ & $\mathrm{x}$ & & & \\
\hline & Cirsium arizonicum (Gray) Petrak & Arizona thistle & $\mathrm{X}$ & & & & \\
\hline & Cirsium wheeleri (Gray) Petrak & Wheeler's thistle & $x$ & & & & \\
\hline & Conyza canadensis (L.) Cronq. & Canadian horseweed & & $\mathrm{X}$ & & & \\
\hline & Conyza canadensis var. pusilla (Nutt.) & & & & & & \\
\hline & Cronq. & Canadian horseweed & $\mathrm{X}$ & & & & \\
\hline & Encelia frutescens (Gray) Gray & button brittlebush & $\mathrm{x}$ & $\mathrm{X}$ & & & $\mathrm{X}$ \\
\hline & Encelia virginensis A. Nels. & Virgin River brittlebush & $x$ & & & & \\
\hline & Erigeron concinnus (Hook. \& Arn.) Torr. \& & & & & & & \\
\hline & Gray & Navajo fleabane & $\mathrm{X}$ & $x$ & & & \\
\hline & Erigeron divergens Torr. \& Gray & spreading fleabane & $\mathrm{x}$ & & & & $\mathrm{X}$ \\
\hline & Erigeron flagellaris Gray & trailing fleabane & $\mathrm{x}$ & & & & $\mathrm{x}$ \\
\hline & Gaillardia pinnatifida Torr. & red dome blanketflower & $\mathrm{x}$ & $\mathrm{X}$ & & & \\
\hline & Grindelia nuda var. aphanactis (Rydb.) & & & & & & \\
\hline & Nesom & curlytop gumweed & $\mathrm{x}$ & $\mathrm{x}$ & & & \\
\hline & Gutierrezia microcephala (DC.) Gray & threadleaf snakeweed & $\mathrm{x}$ & & & & \\
\hline & Gutierrezia sarothrae (Pursh) Britt. \& Rusby & broom snakeweed & $\mathrm{x}$ & $\mathrm{X}$ & & & $\mathrm{x}$ \\
\hline & Helianthus annuus $\mathrm{L}$. & common sunflower & $x$ & & & $\mathrm{X}$ & \\
\hline & Heliomeris multiflora var. multiflora Nutt. & showy goldeneye & $\mathrm{x}$ & & & & \\
\hline & Heterotheca subaxillaris (Lam.) Britt. \& & & & & & & \\
\hline & Rusby & camphorweed & & $\mathrm{x}$ & $\mathrm{x}$ & $\mathrm{X}$ & \\
\hline & Heterotheca villosa (Pursh) Shinners & hairy false goldenaster & & $\mathrm{x}$ & & & \\
\hline & Heterotheca villosa var. foliosa (Nutt.) & & & & & & \\
\hline & Harms & hairy false goldenaster & $\mathrm{x}$ & & & & \\
\hline & Hymenoclea monogyra Torr. \& Gray ex Gray & / singlewhorl burrobrush & $\mathrm{x}$ & $\mathrm{x}$ & & & $\mathrm{x}$ \\
\hline & Hymenothrix loomisii Blake & Loomis' thimblehead & $\mathrm{X}$ & & & & \\
\hline & Lactuca serriola L. & prickly lettuce & & & $\mathrm{X}$ & $\mathbf{x}$ & \\
\hline & Lactuca tatarica var. pulchella (Pursh) & & & & & & \\
\hline & Breitung & blue lettuce & $\mathrm{X}$ & & & & \\
\hline & Layia glandulosa (Hook.) Hook. \& Arn. & whitedaisy tidytips & $x$ & & & & $\mathrm{x}$ \\
\hline & $\begin{array}{l}\text { Machaeranthera canescens var. incana } \\
\text { (Lindl.) Gray }\end{array}$ & hoary tansyaster & $\mathrm{x}$ & & & & \\
\hline & Machaeranthera gracilis (Nutt.) Shinners & slender goldenweed & $\mathrm{x}$ & & & & \\
\hline & Malacothrix fendleri Gray & Fendler's desertdandelion & $x$ & & & & \\
\hline & Melampodium leucanthum Torr. \& Gray & plains blackfoot & $\mathrm{X}$ & $\mathrm{X}$ & & & $x$ \\
\hline & $\begin{array}{l}\text { Packera neomexicana var. neomexicana } \\
\text { (Gray) W.A. Weber \& A. Löve }\end{array}$ & New Mexico groundsel & $\mathrm{x}$ & & & & \\
\hline & Packera quercetorum (Greene) C. Jeffrey & Oak Creek ragwort & $\mathrm{x}$ & & & & \\
\hline & Parthenium incanum Kunth & mariola & $\mathrm{x}$ & $\mathrm{X}$ & & & $x$ \\
\hline & Senecio flaccidus var. flaccidus Less. & threadleaf ragwort & $\mathrm{x}$ & & & & \\
\hline & Solidago velutina DC. & threenerve goldenrod & $\mathrm{X}$ & & & & \\
\hline & Solidago wrightii Gray & Wright's goldenrod & $\mathrm{x}$ & $\mathrm{X}$ & & & \\
\hline & Sonchus asper (L.) Hill & spiny sowthistle & $\mathbf{x}$ & $\mathbf{x}$ & & & \\
\hline & Stephanomeria exigua Nutt. & small wirelettuce & $\mathrm{x}$ & & & & \\
\hline & Stephanomeria minor var. minor (Hook.) & & & & & & \\
\hline & Nutt. & narrowleaf wirelettuce & $\mathrm{x}$ & & & & \\
\hline
\end{tabular}




\begin{tabular}{|c|c|c|c|c|c|c|c|}
\hline Family & Scientific name & Common name & B\&R & Row & $H \& G$ & Mau & NPS \\
\hline \multirow[t]{15}{*}{ Asteraceae } & Stephanomeria pauciflora (Torr.) A. Nels. & brownplume wirelettuce & $x$ & $\mathrm{x}$ & & & $\mathrm{X}$ \\
\hline & Symphyotrichum divaricatum (Nutt.) Nesom & southern annual saltmarsh aster & $\mathrm{x}$ & & & & \\
\hline & $\begin{array}{l}\text { Symphyotrichum praealtum var. praealtum } \\
\text { (Poir.) Nesom }\end{array}$ & willowleaf aster & $\mathrm{x}$ & & & & \\
\hline & Taraxacum laevigatum (Willd.) DC. & rock dandelion & $\mathrm{x}$ & $\mathrm{x}$ & & & \\
\hline & Thymophylla acerosa (DC.) Strother & pricklyleaf dogweed & $\mathrm{x}$ & $\mathrm{x}$ & & & $\mathrm{X}$ \\
\hline & $\begin{array}{l}\text { Thymophylla pentachaeta var. belenidium } \\
\text { (DC.) Strother }\end{array}$ & fiveneedle pricklyleaf & $\mathrm{x}$ & & & & \\
\hline & $\begin{array}{l}\text { Thymophylla pentachaeta var. pentachaeta } \\
\text { (DC.) Small }\end{array}$ & fiveneedle pricklyleaf & & & & & $\mathrm{x}$ \\
\hline & Townsendia annua Beaman & annual Townsend daisy & $\mathrm{x}$ & & & & \\
\hline & Townsendia strigosa Nutt. & hairy Townsend daisy & $x$ & & & & $\mathrm{x}$ \\
\hline & Tragopogon dubius Scop. & yellow salsify & $\mathrm{x}$ & $\mathrm{x}$ & & & \\
\hline & Uropappus lindleyi (DC.) Nutt. & Lindley's silverpuffs & $\mathrm{x}$ & & & & $\mathrm{x}$ \\
\hline & Verbesina encelioides (Cav.) Benth. \& & & & & & & \\
\hline & Hook. f. ex Gray & golden crownbeard & $x$ & $x$ & & & \\
\hline & $\begin{array}{l}\text { Verbesina encelioides ssp. exauriculata } \\
\text { (Robins. \& Greenm.) J.R. Coleman }\end{array}$ & golden crownbeard & $\mathrm{x}$ & & & & \\
\hline & Xanthium strumarium L. & rough cockleburr & $\mathrm{x}$ & $\mathrm{x}$ & $\mathrm{x}$ & $\mathrm{X}$ & \\
\hline Berberidaceae & Mahonia haematocarpa (Woot.) Fedde & red barberry & $\mathrm{x}$ & $\mathrm{x}$ & & & $\mathrm{x}$ \\
\hline Betulaceae & Alnus oblongifolia Torr. & Arizona alder & $\mathrm{x}$ & $\mathrm{x}$ & & & \\
\hline \multirow[t]{3}{*}{ Bignoniaceae } & Chilopsis linearis (Cav.) Sweet & desert willow & & $x$ & & & \\
\hline & Chilopsis linearis ssp. arcuata (Fosberg) & & & & & & \\
\hline & Henrickson & desert willow & $\mathrm{x}$ & & & & \\
\hline \multirow[t]{15}{*}{ Boraginaceae } & Amsinckia menziesii var. intermedia (Fisch & & & & & & \\
\hline & \& C.A. Mey.) Ganders & common fiddleneck & $\mathrm{x}$ & & & & $\mathrm{x}$ \\
\hline & Cryptantha confertiflora (Greene) & basin yellow cryptantha & $\mathrm{x}$ & $\mathrm{x}$ & & & $\mathrm{x}$ \\
\hline & Cryptantha crassisepala (Torr. \& Gray) & & & & & & \\
\hline & Greene & thicksepal cryptantha & $\mathrm{x}$ & & & & $\mathrm{x}$ \\
\hline & Cryptantha nevadensis A. Nels. \& Kennedy & Nevada cryptantha & $\mathrm{x}$ & & & & $\mathrm{X}$ \\
\hline & Harpagonella Gray & grapplinghook & & & & & $\mathrm{x}$ \\
\hline & Lappula occidentalis (S. Wats.) Greene & flatspine stickseed & & & & & $\mathrm{x}$ \\
\hline & Lappula occidentalis var. cupulata (Gray) & & & & & & \\
\hline & Higgins & flatspine stickseed & $\mathrm{x}$ & & & & \\
\hline & Lappula occidentalis var. occidentalis (S. & & & & & & \\
\hline & Wats.) Greene & flatspine stickseed & $\mathrm{x}$ & $\mathrm{x}$ & & & $\mathrm{x}$ \\
\hline & Lithospermum incisum Lehm. & narrowleaf stoneseed & $\mathrm{x}$ & $\mathrm{X}$ & & & \\
\hline & Plagiobothrys Fisch. \& C.A. Mey. & popcornflower & & & & & $\mathrm{x}$ \\
\hline & Tiquilia canescens (DC.) A. Richards. & woody crinklemat & $\mathrm{x}$ & $\mathrm{x}$ & & & $\mathrm{x}$ \\
\hline \multirow[t]{11}{*}{ Brassicaceae } & Arabis perennans $\mathrm{S}$. Wats. & perennial rockcress & $\mathrm{x}$ & & & & \\
\hline & Brassica tournefortii Gouan & Asian mustard & & & & $\mathbf{X}$ & \\
\hline & Capsella bursa-pastoris (L.) Medik. & shepherd's purse & $\mathbf{x}$ & $\mathrm{X}$ & & & $\mathbf{x}$ \\
\hline & Chorispora tenella (Pallas) DC. & crossflower & $\mathrm{x}$ & $\mathbf{x}$ & & & $\mathbf{x}$ \\
\hline & Descurainia pinnata (Walt.) Britt. & western tansymustard & $\mathrm{x}$ & & & & $\mathrm{x}$ \\
\hline & Descurainia sophia (L.) Webb ex Prantl & herb sophia & $\mathrm{x}$ & $\mathrm{X}$ & $\mathbf{x}$ & & \\
\hline & Draba cuneifolia Nutt. ex Torr. \& Gray & wedgeleaf draba & $\mathrm{x}$ & & & & $\mathrm{x}$ \\
\hline & Erysimum capitatum var. purshii (Dur.) & & & & & & \\
\hline & Rollins & Pursh's wallflower & $\mathrm{x}$ & & & & \\
\hline & Lepidium lasiocarpum Nutt. & shaggyfruit pepperweed & $\mathrm{x}$ & & & & $\mathrm{x}$ \\
\hline & Lepidium montanum Nutt. & mountain pepperweed & $\mathrm{x}$ & $\mathrm{x}$ & & & $x$ \\
\hline
\end{tabular}




\begin{tabular}{|c|c|c|c|c|c|c|c|}
\hline Family & Scientific name & Common name & $\mathrm{B} \& \mathrm{R}$ & Row & $H \& G$ & Mau & NPS \\
\hline \multirow[t]{11}{*}{ Brassicaceae } & Lepidium montanum var. glabrum C.L. & & & & & & \\
\hline & Hitchc. & mountain pepperweed & $x$ & & & & \\
\hline & Lesquerella gordonii (Gray) S. Wats. & Gordon's bladderpod & $x$ & & & & \\
\hline & Lesquerella intermedia (S. Wats.) Heller & mid bladderpod & $x$ & & & & \\
\hline & Lesquerella tenella A. Nels. & Moapa bladderpod & $x$ & & & & \\
\hline & Matthiola longipetala (Vent.) DC. & night scented stock & & & & & $x$ \\
\hline & Rorippa nasturtium-aquaticum (L.) Hayek & watercress & $x$ & $x$ & & & \\
\hline & Sisymbrium irio L. & London rocket & $x$ & $\mathrm{X}$ & $x$ & $\mathbf{x}$ & $x$ \\
\hline & Streptanthus carinatus ssp. arizonicus (S. & & & & & & \\
\hline & Wats.) Kruckeberg, Rodman \& Worthington & lyreleaf jewelflower & $x$ & & & & $x$ \\
\hline & Thelypodium wrightii Gray & Wright's thelypody & $x$ & & & & \\
\hline \multirow[t]{10}{*}{ Cactaceae } & Echinocereus fendleri var. boyce-thompsonii & & & & & & \\
\hline & (Orcutt) L. Benson & Boyce Thompson hedgehog ce & us $\mathrm{X}$ & $x$ & & & \\
\hline & $\begin{array}{l}\text { Echinocereus fendleri var. fasciculatus } \\
\text { (Engelm. ex B.D. Jackson) N.P. Taylor }\end{array}$ & pinkflower hedgehog cactus & & & & & $x$ \\
\hline & Escobaria vivipara var. arizonica (Engelm.) & & & & & & \\
\hline & D.R. Hunt & Arizona spinystar & $x$ & & & & \\
\hline & $\begin{array}{l}\text { Opuntia engelmannii Salm-Dyck var. } \\
\text { engelmannii }\end{array}$ & cactus apple & $x$ & & & & \\
\hline & Opuntia leptocaulis DC. & Christmas cactus & $x$ & $x$ & & & $x$ \\
\hline & Opuntia macrocentra var. macrocentra & & & & & & \\
\hline & Engelm. & purple pricklypear & $x$ & & & & \\
\hline & Opuntia phaeacantha Engelm. & tulip pricklypear & & $x$ & & & $x$ \\
\hline \multirow[t]{3}{*}{ Campanulaceae } & Lobelia cardinalis L. & cardinalflower & $x$ & & & & \\
\hline & Nemacladus glanduliferus var. orientalis & & & & & & \\
\hline & McVaugh $\ldots \ldots \ldots \ldots \ldots \ldots \ldots$ & glandular threadplant & $x$ & & & & \\
\hline \multirow[t]{2}{*}{ Capparaceae } & Cleome lutea var. jonesii J.F. Macbr. & Jones spiderflower & $x$ & & & & \\
\hline & $\begin{array}{l}\text { Polanisia dodecandra ssp. trachysperma } \\
\text { (Torr. \& Gray) Iltis }\end{array}$ & sandyseed clammyweed & $x$ & & & & \\
\hline Caryophyllaceae & Silene antirrhina $\mathrm{L}$. & sleepy silene & $x$ & & & & $x$ \\
\hline Celastraceae & Canotia holacantha Torr. & crucifixion thorn & $x$ & $x$ & & & $x$ \\
\hline \multirow[t]{6}{*}{ Chenopodiaceae } & Atriplex canescens (Pursh) Nutt. & fourwing saltbush & $x$ & $x$ & & & $x$ \\
\hline & $\begin{array}{l}\text { Atriplex canescens (Pursh) Nutt. var. } \\
\text { canescens }\end{array}$ & fourwing saltbush & $x$ & & & & \\
\hline & Chenopodium fremontii S. Wats. & Fremont's goosefoot & $x$ & & & & \\
\hline & Krascheninnikovia lanata (Pursh) A.D.J. & & & & & & \\
\hline & Meeuse \& Smit & winterfat & $x$ & $x$ & & & \\
\hline & Salsola tragus $\mathrm{L}$. & prickly Russian thistle & $x$ & $x$ & & & \\
\hline \multirow[t]{3}{*}{ Convolvulaceae } & Convolvulus arvensis $\mathrm{L}$. & field bindweed & $\mathrm{x}$ & $x$ & & & \\
\hline & Convolvulus equitans Benth. & Texas bindweed & $x$ & & & & \\
\hline & Evolvulus nuttallianus J.A. Schultes & shaggy dwarf morning-glory & $x$ & & & & \\
\hline \multirow[t]{2}{*}{ Cucurbitaceae } & Cucurbita foetidissima Kunth & Missouri gourd & $x$ & & & & \\
\hline & Marah gilensis Greene & Gila manroot & $x$ & $x$ & & & $x$ \\
\hline \multirow[t]{3}{*}{ Cupressaceae } & Cupressus arizonica Greene & Arizona cypress & $x$ & & & & $x$ \\
\hline & Juniperus monosperma (Engelm.) Sarg. & oneseed juniper & $x$ & $x$ & & & \\
\hline & Juniperus osteosperma (Torr.) Little & Utah juniper & $x$ & $x$ & & & $x$ \\
\hline \multirow[t]{3}{*}{ Cyperaceae } & Carex aquatilis Wahlenb. & water sedge & $x$ & & & & \\
\hline & Cyperus esculentus $\mathrm{L}$. & chufa flatsedge & & & $\mathbf{x}$ & $\mathbf{X}$ & \\
\hline & Eleocharis parishii Britt. & Parish's spikerush & $x$ & & & & \\
\hline
\end{tabular}




\begin{tabular}{|c|c|c|c|c|c|c|c|}
\hline Family & Scientific name & Common name & $B \& R$ & Row & $H \& G$ & Mau & NPS \\
\hline Cyperaceae & $\begin{array}{l}\text { Schoenoplectus tabernaemontani (K.C. } \\
\text { Gmel.) Palla }\end{array}$ & & $\mathrm{x}$ & & & & \\
\hline Ephedraceae & Ephedra viridis Coville & mormon tea & $x$ & $\mathrm{x}$ & & & $x$ \\
\hline \multirow[t]{13}{*}{ Euphorbiaceae } & Chamaesyce albomarginata (Torr. \& Gray) & & & & & & \\
\hline & Small & whitemargin sandmat & $\mathrm{x}$ & $\mathrm{x}$ & & & \\
\hline & Chamaesyce capitellata (Engelm.) Millsp. & head sandmat & $\mathrm{x}$ & & & & \\
\hline & Chamaesyce chaetocalyx (Boiss.) Woot. \& & & & & & & \\
\hline & Standl. var. chaetocalyx & bristlecup sandmat & $x$ & & & & \\
\hline & Chamaesyce fendleri (Torr. \& Gray) Small & Fendler's sandmat & $\mathrm{x}$ & & & & \\
\hline & Chamaesyce polycarpa (Benth.) Millsp. ex & & & & & & \\
\hline & Parish & smallseed sandmat & & & & & $x$ \\
\hline & Chamaesyce stictospora (Engelm.) Small & slimseed sandmat & $x$ & & & & \\
\hline & Croton texensis (Klotzsch) Muell.-Arg. & Texas croton & $\mathrm{x}$ & $\mathrm{x}$ & & & \\
\hline & Euphorbia brachycera Engelm. & horned spurge & $x$ & & & & \\
\hline & Euphorbia spathulata Lam. & warty spurge & & & & & $x$ \\
\hline & Tragia ramosa Torr. & branched noseburn & $x$ & & & & \\
\hline \multirow[t]{32}{*}{ Fabaceae } & Acacia greggii Gray & catclaw acacia & $\mathrm{x}$ & $x$ & & & $x$ \\
\hline & Amorpha fruticosa $L$. & desert false indigo & $\mathrm{x}$ & $x$ & & & \\
\hline & Astragalus allochrous var. playanus Isely & halfmoon milkvetch & $\mathrm{x}$ & & & & \\
\hline & Astragalus amphioxys Gray & Crescent milkvetch & $x$ & & & & \\
\hline & Astragalus calycosus Torr. ex S. Wats. & Torrey's milkvetch & & $x$ & & & $x$ \\
\hline & Astragalus calycosus var. scaposus (Gray) & & & & & & \\
\hline & M.E. Jones & Torrey's milkvetch & $x$ & & & & \\
\hline & Astragalus lentiginosus Dougl. ex Hook. & freckled milkvetch & & $x$ & & & \\
\hline & Astragalus lentiginosus var. diphysus (Gray & & & & & & \\
\hline & M.E. Jones & freckled milkvetch & $x$ & & & & $\mathrm{x}$ \\
\hline & $\begin{array}{l}\text { Astragalus lentiginosus var. palans (M.E. } \\
\text { Jones) M.E. Jones }\end{array}$ & freckled milkvetch & $\mathrm{x}$ & & & & \\
\hline & Astragalus newberryi Gray & Newberry's milkvetch & $x$ & $\mathrm{x}$ & & & \\
\hline & Astragalus nuttallianus DC. & smallflowered milkvetch & $x$ & & & & $\mathrm{x}$ \\
\hline & Astragalus nuttallianus var. trichocarpus & & & & & & \\
\hline & Torr. \& Gray & turkeypeas & $\mathrm{x}$ & & & & \\
\hline & Astragalus subcinereus Gray & Silver's milkvetch & $x$ & & & & \\
\hline & Astragalus tephrodes Gray & ashen milkvetch & & & & & $\mathrm{x}$ \\
\hline & $\begin{array}{l}\text { Astragalus tephrodes var. brachylobus } \\
\text { (Grav) Barneby }\end{array}$ & ashen milkvetch & $x$ & & & & \\
\hline & Caesalpinia drepanocarpa (Gray) Fisher & sicklepod holdback & $x$ & $x$ & & & \\
\hline & Dalea formosa Torr. & featherplume & $x$ & $x$ & & & $x$ \\
\hline & Dalea searlsiae (Gray) Barneby & Searls' prairie clover & $x$ & & & & \\
\hline & Desmanthus cooleyi (Eat.) Trel. & Cooley's bundleflower & $x$ & & & & \\
\hline & Lathyrus eucosmus Butters \& St. John & bush vetchling & & & & & $\mathrm{x}$ \\
\hline & Lotus corniculatus $\mathrm{L}$. & birdfoot deervetch & $\mathrm{x}$ & & & & $x$ \\
\hline & Lotus humistratus Greene & foothill deervetch & $x$ & & & & $x$ \\
\hline & Lotus mearnsii (Britt.) Greene & Mearns' bird's-foot trefoil & $x$ & & & & \\
\hline & Lupinus brevicaulis S. Wats. & shortstem lupine & $x$ & & & & \\
\hline & Lupinus concinnus J.G. Agardh & scarlet lupine & & & & & $x$ \\
\hline & Lupinus sparsiflorus Benth. & Mojave lupine & & & & & $x$ \\
\hline & Medicago lupulina L. & black medick & $\mathrm{x}$ & $\mathrm{x}$ & & & \\
\hline & Medicago minima (L.) L. & burr medick & $x$ & $x$ & & & \\
\hline & Medicago polymorpha L. & burclover & $x$ & $\mathrm{x}$ & & & \\
\hline
\end{tabular}




\begin{tabular}{|c|c|c|c|c|c|c|c|}
\hline Family & Scientific name & Common name & $\mathrm{B} \& \mathrm{R}$ & Row & $H \& G$ & Mau & NPS \\
\hline \multirow[t]{11}{*}{ Fabaceae } & Medicago sativa $\mathrm{L}$. & alfalfa & $\mathrm{X}$ & $x$ & & & \\
\hline & Melilotus indicus (L.) All. & annual yellow sweetclover & $\mathbf{x}$ & $x$ & & $\mathrm{X}$ & \\
\hline & Melilotus officinalis (L.) Lam. & yellow sweetclover & $x$ & $X$ & $X$ & $X$ & \\
\hline & Mimosa aculeaticarpa Ortega & catclaw mimosa & & & & & $x$ \\
\hline & $\begin{array}{l}\text { Mimosa aculeaticarpa var. biuncifera } \\
\text { (Benth.) Barneby }\end{array}$ & catclaw mimosa & $x$ & $x$ & & & \\
\hline & Phaseolus angustissimus Gray & slimleaf bean & $x$ & & & & \\
\hline & Prosopis velutina Woot. & velvet mesquite & $x$ & $x$ & & & $x$ \\
\hline & Rhynchosia senna var. texana (Torr. \& & Texas snoutbean & $x$ & & & & \\
\hline & Senna bauhinioides (Gray) Irwin \& Barneby & twinleaf senna & $x$ & $x$ & & & $x$ \\
\hline & Trifolium repens $L$. & white clover & $x$ & $\mathrm{X}$ & & & \\
\hline & Vicia ludoviciana Nutt. & Louisiana vetch & $x$ & $x$ & & & $x$ \\
\hline \multirow[t]{2}{*}{ Fagaceae } & Quercus dunnii Kellogg & Palmer oak & $x$ & & & & \\
\hline & Quercus turbinella Greene & Sonoran scrub oak & $x$ & $x$ & & & \\
\hline \multirow[t]{2}{*}{ Fumariaceae } & Corydalis aurea Willd. & scrambled eggs & $x$ & & & & $x$ \\
\hline & $\begin{array}{l}\text { Corydalis curvisiliqua ssp. occidentalis } \\
\text { (Engelm. ex Gray) W.A. Weber }\end{array}$ & curvepod fumewort & $x$ & & & & \\
\hline \multirow[t]{2}{*}{ Geraniaceae } & Erodium cicutarium (L.) L'Hér. ex Ait. & redstem stork's bill & $\mathbf{x}$ & $x$ & $x$ & $\mathrm{X}$ & $\mathbf{x}$ \\
\hline & Erodium texanum Gray & Texas stork's bill & $x$ & & & & $x$ \\
\hline Grossulariaceae & Ribes aureum Pursh & golden currant & $x$ & & & & \\
\hline \multirow[t]{7}{*}{ Hydrophyllaceae } & $\begin{array}{l}\text { Eucrypta chrysanthemifolia var. } \\
\text { bipinnatifida (Torr.) Constance }\end{array}$ & spotted hideseed & $x$ & & & & \\
\hline & Eucrypta micrantha (Torr.) Heller & dainty desert hideseed & $x$ & & & & \\
\hline & Phacelia crenulata Torr. ex S. Wats. & cleftleaf wildheliotrope & $x$ & & & & $X$ \\
\hline & Phacelia cryptantha Greene & hiddenflower phacelia & $x$ & & & & \\
\hline & Phacelia distans Benth. & distant phacelia & $x$ & & & & \\
\hline & Phacelia ivesiana Torr. & Ives' phacelia & $x$ & & & & \\
\hline & Phacelia rotundifolia Torr. ex S. Wats. & roundleaf phacelia & $x$ & & & & \\
\hline Juglandaceae & Juglans major (Torr.) Heller & Arizona walnut & $x$ & $x$ & & & $x$ \\
\hline \multirow[t]{3}{*}{ Juncaceae } & Juncus saximontanus A. Nels. & Rocky Mountain rush & $x$ & & & & \\
\hline & Juncus torreyi Coville & Torrey's rush & $x$ & & & & \\
\hline & Juncus xiphioides E. Mey. & irisleaf rush & $x$ & & & & \\
\hline Krameriaceae & Krameria erecta Willd. ex J.A. Schultes & littleleaf ratany & $x$ & $x$ & & & $x$ \\
\hline \multirow[t]{7}{*}{ Lamiaceae } & Hedeoma drummondii Benth. & Drummond's false pennyroyal & $x$ & & & & \\
\hline & Hedeoma nana (Torr.) Briq. & dwarf false pennyroyal & $x$ & $\mathrm{X}$ & & & $x$ \\
\hline & Hedeoma oblongifolia (Gray) Heller & oblongleaf false pennyroyal & $x$ & & & & $x$ \\
\hline & Lamium amplexicaule L. & henbit deadnettle & & & & & $\mathrm{X}$ \\
\hline & Marrubium vulgare $\mathrm{L}$. & horehound & $\mathrm{X}$ & $\mathbf{X}$ & $\mathbf{X}$ & $\mathrm{X}$ & $\mathbf{X}$ \\
\hline & Mentha spicata L. & spearmint & $\mathbf{x}$ & $\mathbf{x}$ & & & \\
\hline & Salvia reflexa Hornem. & lanceleaf sage & $x$ & & & & \\
\hline \multirow[t]{5}{*}{ Liliaceae } & Calochortus flexuosus S. Wats. & winding mariposa lily & $x$ & $x$ & & & $x$ \\
\hline & Calochortus nuttallii Torr. \& Gray & sego lily & $x$ & & & & \\
\hline & $\begin{array}{l}\text { Dichelostemma capitatum (Benth.) Wood } \\
\text { ssp. capitatum }\end{array}$ & bluedicks & $x$ & $x$ & & & $x$ \\
\hline & $\begin{array}{l}\text { Dichelostemma capitatum ssp. } \\
\text { pauciflorum (Torr.) G. Keator }\end{array}$ & bluedicks & $x$ & & & & \\
\hline & Nolina microcarpa S. Wats. & sacahuista & $x$ & & & & \\
\hline \multirow[t]{2}{*}{ Linaceae } & Linum lewisii Pursh & prairie flax & $x$ & & & & \\
\hline & Linum puberulum (Engelm.) Heller & plains flax & $x$ & & & & \\
\hline
\end{tabular}




\begin{tabular}{|c|c|c|c|c|c|c|c|}
\hline Family & Scientific name & Common name & $B \& R$ & Row & $H \& G$ & Mau & NPS \\
\hline \multirow[t]{4}{*}{ Loasaceae } & Mentzelia albicaulis (Dougl. ex Hook.) & & & & & & \\
\hline & Dougl. ex Torr. \& Gray & whitestem blazingstar & $\mathrm{x}$ & & & & \\
\hline & $\begin{array}{l}\text { Mentzelia multiflora (Nutt.) Gray var. } \\
\text { multiflora }\end{array}$ & Adonis blazingstar & $\mathrm{x}$ & & & & \\
\hline & Mentzelia pumila Nutt. ex Torr. \& Gray & dwarf mentzelia & & $\mathrm{x}$ & & & \\
\hline Lythraceae & Lythrum californicum Torr. \& Gray & California loosestrife & $\mathrm{x}$ & & & & \\
\hline \multirow[t]{7}{*}{ Malvaceae } & Abutilon parvulum Gray & dwarf Indian mallow & $\mathrm{x}$ & & & & \\
\hline & Malva neglecta Wallr. & common mallow & $\mathrm{x}$ & $\mathbf{x}$ & & & $\mathrm{x}$ \\
\hline & Sphaeralcea ambigua Gray & desert globemallow & $\mathrm{x}$ & $\mathrm{x}$ & & & \\
\hline & Sphaeralcea grossulariifolia (Hook. \& Arn.) & & & & & & \\
\hline & Rydb. & gooseberryleaf globemallow & $\mathrm{x}$ & & & & \\
\hline & Sphaeralcea parvifolia A. Nels. & smallflower globemallow & $\mathrm{x}$ & & & & $\mathrm{x}$ \\
\hline & Sphaeralcea rusbyi Gray & Rusby's globemallow & $\mathrm{x}$ & & & & \\
\hline \multirow[t]{7}{*}{ Nyctaginaceae } & Allionia incarnata L. & trailing windmills & $\mathrm{x}$ & $x$ & & & \\
\hline & Boerhavia coccinea P. Mill. & scarlet spiderling & $\mathrm{x}$ & & $\mathrm{x}$ & $\mathrm{x}$ & \\
\hline & Boerhavia coulteri (Hook. f.) S. Wats. & Coulter's spiderling & $\mathrm{x}$ & & & & \\
\hline & Boerhavia spicata Choisy & creeping spiderling & $\mathrm{x}$ & & & & \\
\hline & Mirabilis multiflora (Torr.) Gray & Colorado four o'clock & & $\mathrm{x}$ & & & \\
\hline & Mirabilis multiflora (Torr.) Gray var. multiflor & aColorado four o'clock & $\mathrm{x}$ & & & & \\
\hline & Mirabilis pumila (Standl.) Standl. & dwarf four o'clock & $\mathrm{x}$ & & & & \\
\hline \multirow[t]{4}{*}{ Oleaceae } & Forestiera pubescens Nutt. & stretchberry & $\mathrm{x}$ & & & & \\
\hline & Forestiera pubescens var. pubescens Nutt. & stretchberry & & & & & $\mathrm{x}$ \\
\hline & Fraxinus velutina Torr. & velvet ash & $\mathrm{x}$ & $\mathrm{x}$ & & & $\mathrm{x}$ \\
\hline & Menodora scabra Gray & rough menodora & $\mathrm{x}$ & $\mathrm{x}$ & & & \\
\hline \multirow[t]{9}{*}{ Onagraceae } & Gaura coccinea Nutt. ex Pursh & scarlet beeblossom & $\mathrm{x}$ & $\mathrm{x}$ & & & $\mathrm{X}$ \\
\hline & Gaura hexandra Ortega & harlequinbush & & $\mathrm{x}$ & & & \\
\hline & Gaura hexandra ssp. gracilis (Woot. \& & & & & & & \\
\hline & Standl.) Raven \& Gregory & harlequinbush & $\mathrm{x}$ & & & & \\
\hline & Gaura mollis James & velvetweed & $\mathrm{x}$ & $\mathrm{x}$ & & & \\
\hline & Oenothera albicaulis Pursh & whitest evening-primrose & $\mathrm{x}$ & & & & $\mathrm{x}$ \\
\hline & Oenothera caespitosa Nutt. & tufted evening-primrose & $x$ & & & & $x$ \\
\hline & $\begin{array}{l}\text { Oenothera caespitosa ssp. marginata (Nutt. } \\
\text { ex Hook. \& Arn.) Munz }\end{array}$ & tufted evening-primrose & $\mathrm{x}$ & & & & \\
\hline & Oenothera flava (A. Nels.) Garrett & yellow evening-primrose & $\mathrm{x}$ & & & & \\
\hline Orchidaceae & Epipactis gigantea Dougl. ex Hook. & stream orchid & $\mathrm{x}$ & & & & \\
\hline \multirow[t]{2}{*}{ Papaveraceae } & Argemone pleiacantha ssp. ambigua G.B. & & & & & & \\
\hline & Ownbey & southwestern pricklypoppy & $x$ & & & & \\
\hline \multirow[t]{2}{*}{ Pedaliaceae } & Proboscidea parviflora (Woot.) Woot. \& & & & & & & \\
\hline & Standl. & doubleclaw & $\mathrm{x}$ & & & & \\
\hline \multirow[t]{2}{*}{ Pinaceae } & Pinus edulis Engelm. & twoneedle pinyon & $\mathrm{x}$ & & & & \\
\hline & Pinus monophylla Torr. \& Frém. & singleleaf pinyon & $\mathrm{x}$ & & & & \\
\hline \multirow[t]{4}{*}{ Plantaginaceae } & Plantago major L. & common plantain & $\mathrm{x}$ & $\mathrm{x}$ & & & \\
\hline & Plantago patagonica Jacq. & woolly plantain & $\mathrm{x}$ & & & & $\mathrm{X}$ \\
\hline & Plantago rhodosperma Dcne. & redseed plantain & $\mathrm{x}$ & & & & $\mathrm{x}$ \\
\hline & Plantago virginica L. & Virginia plantain & $\mathrm{x}$ & & & & \\
\hline Platanaceae & Platanus wrightii S. Wats. & Arizona sycamore & $\mathrm{x}$ & $\mathrm{x}$ & & & $\mathrm{x}$ \\
\hline \multirow[t]{4}{*}{ Poaceae } & Achnatherum hymenoides (Roemer \& J.A. & & & & & & \\
\hline & Schultes) Barkworth & Indian ricegrass & $\mathrm{x}$ & $\mathrm{x}$ & & & $\mathrm{x}$ \\
\hline & Andropogon gerardii Vitman & big bluestem & & $\mathrm{x}$ & & & \\
\hline & Aristida purpurea Nutt. & purple threeawn & $\mathrm{x}$ & $X$ & & & $\mathrm{X}$ \\
\hline
\end{tabular}




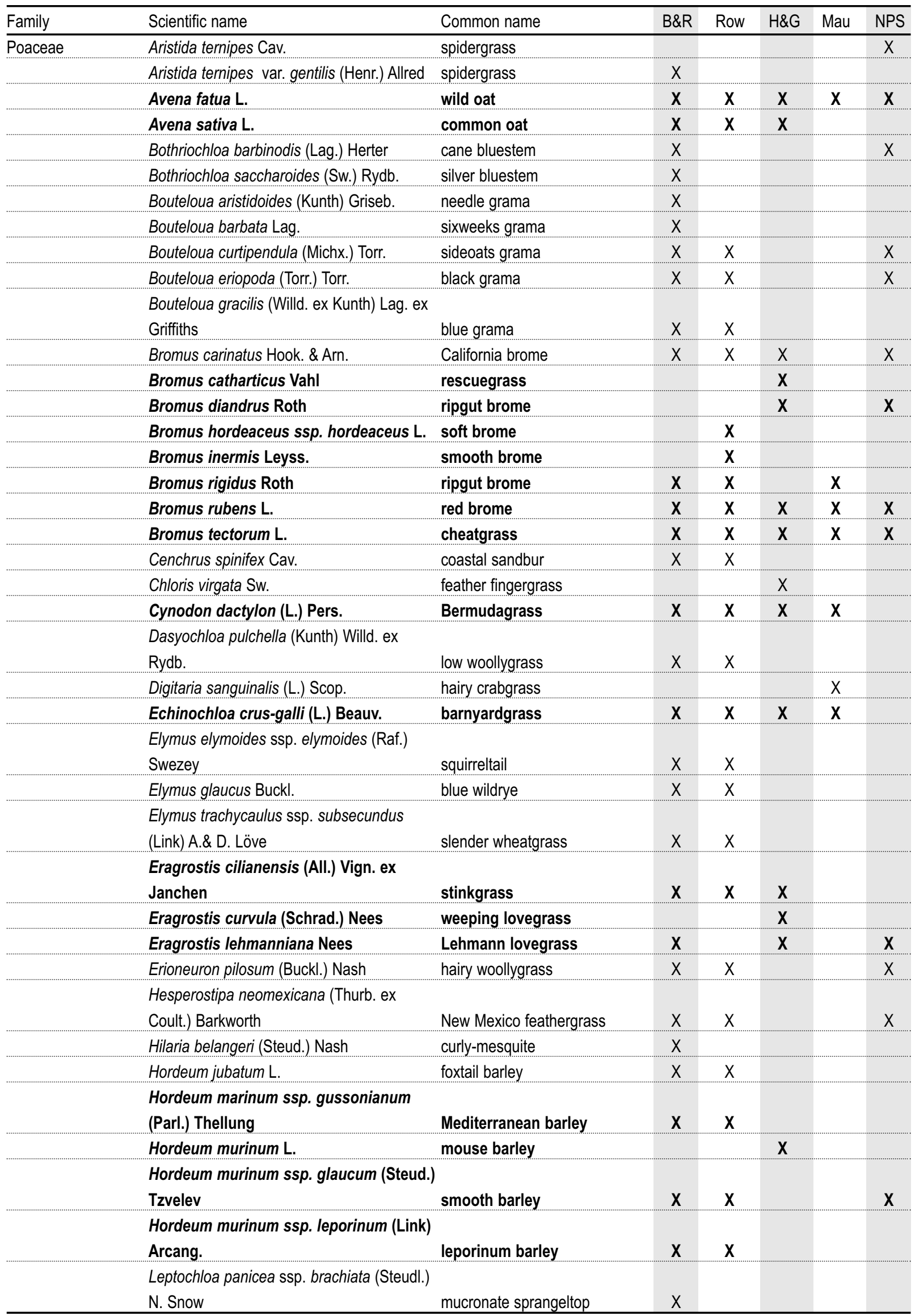




\begin{tabular}{|c|c|c|c|c|c|c|c|}
\hline Family & Scientific name & Common name & B\&R & Row & $H \& G$ & Mau & NPS \\
\hline \multirow[t]{25}{*}{ Poaceae } & Muhlenbergia asperifolia (Nees \& Meyen & & & & & & \\
\hline & ex Trin.) Parodi & scratchgrass & $\mathrm{x}$ & $\mathrm{x}$ & & & \\
\hline & Muhlenbergia porteri Scribn. ex Beal & bush muhly & $x$ & $\mathrm{x}$ & & & $\mathrm{x}$ \\
\hline & Paspalum distichum $\mathrm{L}$. & knotgrass & $x$ & & & & \\
\hline & Pleuraphis mutica Buckl. & tobosagrass & $\mathrm{x}$ & $\mathrm{x}$ & & & $\mathrm{x}$ \\
\hline & Poa bigelovii Vasey \& Scribn. & Bigelow's bluegrass & $\mathrm{x}$ & & & & \\
\hline & Poa fendleriana (Steud.) Vasey & muttongrass & $x$ & & & & $x$ \\
\hline & $\begin{array}{l}\text { Poa fendleriana ssp. Iongiligula (Scribn. } \\
\text { \& Williams) Soreng }\end{array}$ & muttongrass & & & & & $\mathrm{x}$ \\
\hline & Polypogon monspeliensis (L.) Desf. & annual rabbitsfoot grass & $\mathrm{x}$ & $\mathrm{x}$ & $\mathrm{x}$ & $\mathrm{x}$ & \\
\hline & Polypogon viridis (Gouan) Breistr. & beardless rabbitsfoot grass & $\mathrm{x}$ & & & & \\
\hline & Schismus barbatus (Loefl. ex L.) & & & & & & \\
\hline & Thellung & common Mediterranean grass & $\mathrm{x}$ & $\mathrm{x}$ & & $\mathrm{X}$ & $\mathrm{x}$ \\
\hline & Schizachyrium Nees & little bluestem & & & & & $\mathrm{X}$ \\
\hline & Setaria grisebachii Fourn. & Grisebach's bristlegrass & $\mathrm{x}$ & & & & \\
\hline & Setaria leucopila (Scribn. \& Merr.) K. & & & & & & \\
\hline & Schum. & streambed bristlegrass & $\mathrm{X}$ & & & & \\
\hline & Setaria viridis (L.) Beauv. & green bristlegrass & $\mathrm{x}$ & $\mathrm{X}$ & & $\mathbf{x}$ & \\
\hline & Setaria vulpiseta (Lam.) Roemer \& J.A. & & & & & & \\
\hline & Schultes & plains bristlegrass & $\mathrm{x}$ & & & & \\
\hline & Sorghum halepense (L.) Pers. & Johnsongrass & $\mathrm{x}$ & $\mathrm{x}$ & $\mathrm{x}$ & $\mathrm{X}$ & $\mathrm{x}$ \\
\hline & Sporobolus airoides (Torr.) Torr. & alkali sacaton & $\mathrm{x}$ & $\mathrm{x}$ & & & \\
\hline & Sporobolus contractus A.S. Hitchc. & spike dropseed & & & & & $\mathrm{x}$ \\
\hline & Sporobolus cryptandrus (Torr.) Gray & sand dropseed & $\mathrm{x}$ & $\mathrm{x}$ & & & \\
\hline & Tridens muticus (Torr.) Nash & slim tridens & $\mathrm{x}$ & & & & \\
\hline & $\begin{array}{l}\text { Urochloa arizonica (Scribn. \& Merr.) } 0 . \\
\text { Morrone \& F. Zuloaga }\end{array}$ & Arizona signalgrass & $\mathrm{x}$ & & & & \\
\hline \multirow[t]{8}{*}{ Polemoniaceae } & Eriastrum diffusum (Gray) Mason & miniature woollystar & & & & & $\mathrm{x}$ \\
\hline & Eriastrum eremicum (Jepson) Mason & desert woollystar & $\mathrm{x}$ & & & & \\
\hline & Gilia flavocincta A. Nels. & lesser yellowthroat gilia & $\mathrm{x}$ & & & & $\mathrm{x}$ \\
\hline & Gilia sinuata Dougl. ex Benth. & rosy gilia & $\mathrm{x}$ & & & & \\
\hline & Ipomopsis longiflora (Torr.) V. Grant & flaxflowered ipomopsis & $\mathrm{x}$ & & & & \\
\hline & Phlox amabilis Brand & Arizona phlox & $\mathrm{x}$ & & & & \\
\hline & Phlox speciosa ssp. woodhousei (Torr. ex & & & & & & \\
\hline & Gray) Wherry & Woodhouse's phlox & $\mathrm{x}$ & $\mathrm{X}$ & & & \\
\hline \multirow[t]{14}{*}{ Polygalaceae } & Polygala rusbyi Greene & Rusby's milkwort & $\mathrm{x}$ & $\mathrm{x}$ & & & $\mathrm{X}$ \\
\hline & Polygala scoparioides Chod. & broom milkwort & $\mathrm{x}$ & & & & \\
\hline & Eriogonum abertianum Torr. var. abertianu & $n$ Abert's buckwheat & $\mathrm{x}$ & & & & \\
\hline & Eriogonum deflexum Torr. & flatcrown buckwheat & & $\mathrm{x}$ & & & \\
\hline & Eriogonum deflexum Torr. var. deflexum & flatcrown buckwheat & $\mathrm{x}$ & & & & \\
\hline & Eriogonum inflatum Torr. \& Frém. & desert trumpet & & & & & $\mathrm{x}$ \\
\hline & $\begin{array}{l}\text { Eriogonum microthecum var. simpsonii } \\
\text { (Benth.) Reveal }\end{array}$ & Simpson's buckwheat & $\mathrm{x}$ & $\mathrm{x}$ & & & \\
\hline & Eriogonum trichopes Torr. & little deserttrumpet & $\mathrm{x}$ & & & & $\mathrm{x}$ \\
\hline & Eriogonum wrightii var. wrightii Torr. ex & & & & & & \\
\hline & Benth. & bastardsage & $\mathrm{x}$ & & & & \\
\hline & Polygonum aviculare L. & prostrate knotweed & $\mathrm{x}$ & $\mathrm{x}$ & $\mathrm{x}$ & $\mathrm{x}$ & \\
\hline & Polygonum punctatum Ell. & dotted smartweed & $\mathrm{x}$ & & & & \\
\hline & Rumex crispus L. & curly dock & $\mathrm{x}$ & $\mathrm{X}$ & & & \\
\hline & Rumex hymenosepalus Torr. & canaigre dock & $\mathrm{x}$ & & & & \\
\hline
\end{tabular}




\begin{tabular}{|c|c|c|c|c|c|c|c|}
\hline Family & Scientific name & Common name & $\mathrm{B} \& \mathrm{R}$ & Row & $H \& G$ & Mau & NPS \\
\hline Portulacaceae & Calandrinia ciliata (Ruiz \& Pavón) DC. & fringed redmaids & $x$ & & & & \\
\hline \multirow[t]{3}{*}{ Potamogetonaceae } & Potamogeton gramineus $\mathrm{L}$. & variableleaf pondweed & $x$ & & & & \\
\hline & Potamogeton nodosus Poir. & longleaf pondweed & $x$ & & & & \\
\hline & Stuckenia pectinatus (L.) Boerner & sago pondweed & $x$ & & & & \\
\hline \multirow[t]{3}{*}{ Primulaceae } & Androsace occidentalis Pursh & western rockjasmine & $x$ & & & & \\
\hline & Samolus valerandi ssp. parviflorus (Raf.) & & & & & & \\
\hline & Hultén & seaside brookweed & $x$ & & & & \\
\hline \multirow[t]{4}{*}{ Ranunculaceae } & Anemone tuberosa Rydb. & tuber anemone & $x$ & & & & $x$ \\
\hline & Aquilegia chrysantha Gray & golden columbine & $x$ & & & & \\
\hline & Clematis ligusticifolia Nutt. & western white clematis & $x$ & & & & \\
\hline & Delphinium scaposum Greene & tall mountain larkspur & $x$ & $x$ & & & \\
\hline \multirow[t]{7}{*}{ Rhamnaceae } & $\begin{array}{l}\text { Frangula californica ssp. californica } \\
\text { (Eschsch.) Gray }\end{array}$ & California buckthorn & & $X$ & & & \\
\hline & Frangula californica ssp. ursina (Greene) & & & & & & \\
\hline & Kartesz \& Gandhi & California buckthorn & $x$ & & & & \\
\hline & Ziziphus obtusifolia (Hook. ex Torr. \& Gray) & & & & & & \\
\hline & Gray & lotebush & & $x$ & & & $X$ \\
\hline & Ziziphus obtusifolia var. canescens (Gray) & & & & & & \\
\hline & M.C. Johnston & lotebush & $x$ & & & & \\
\hline \multirow[t]{2}{*}{ Rosaceae } & Purshia stansburiana (Torr.) Henrickson & Stansbury cliffrose & $x$ & $X$ & & & $X$ \\
\hline & Rubus arizonensis Focke & Arizona dewberry & $x$ & & & & \\
\hline \multirow[t]{3}{*}{ Rubiaceae } & Galium aparine L. & stickywilly & $x$ & $x$ & & & \\
\hline & Galium microphyllum Gray & bracted bedstraw & $x$ & & & & \\
\hline & Galium proliferum Gray & limestone bedstraw & $x$ & & & & $x$ \\
\hline \multirow[t]{4}{*}{ Rutaceae } & Ptelea trifoliata L. & common hoptree & & & & & $x$ \\
\hline & Ptelea trifoliata ssp. pallida (Greene) V. & & & & & & \\
\hline & Bailey & pallid hoptree & $x$ & & & & \\
\hline & Thamnosma texana (Gray) Torr. & rue of the mountains & $x$ & $X$ & & & \\
\hline \multirow[t]{4}{*}{ Salicaceae } & Salix amygdaloides Anderss. & peachleaf willow & $x$ & & & & \\
\hline & Salix bonplandiana Kunth & Bonpland willow & $x$ & & & & \\
\hline & Salix exigua Nutt. & narrowleaf willow & & $\mathrm{X}$ & & & \\
\hline & Salix gooddingii Ball & Goodding's willow & $x$ & $\mathrm{X}$ & & & \\
\hline \multirow[t]{3}{*}{ Sapindaceae } & Sapindus saponaria L. & wingleaf soapberry & & $x$ & & & \\
\hline & Sapindus saponaria var. drummondii (Hook & & & & & & \\
\hline & \& Arn.) L. Benson & western soapberry & $X$ & & & & \\
\hline \multirow[t]{12}{*}{ Scrophulariaceae } & Castilleja applegatei ssp. martinii (Abrams) & & & & & & \\
\hline & Chuang \& Heckard & wavyleaf Indian paintbrush & $x$ & $x$ & & & $x$ \\
\hline & Castilleja integra Gray & wholeleaf Indian paintbrush & $x$ & & & & \\
\hline & Cordylanthus laxiflorus Gray & nodding bird's-beak & $x$ & & & & \\
\hline & Linaria dalmatica (L.) P. Mill. & Dalmatian toadflax & $x$ & $x$ & & $\mathbf{x}$ & $x$ \\
\hline & $\begin{array}{l}\text { Maurandella antirrhiniflora (Humb. \& Bonpl. } \\
\text { ex Willd.) Rothm. }\end{array}$ & roving sailor & $x$ & $X$ & & & \\
\hline & Mimulus guttatus DC. & seep monkeyflower & $x$ & & & & \\
\hline & Mimulus rubellus Gray & little redstem monkeyflower & $x$ & & & & \\
\hline & $\begin{array}{l}\text { Penstemon eatonii ssp. undosus (M.E. } \\
\text { Jones) Keck }\end{array}$ & Eaton's penstemon & $x$ & & & & \\
\hline & Penstemon pseudospectabilis M.E. Jones & desert penstemon & & $x$ & & & \\
\hline & $\begin{array}{l}\text { Penstemon pseudospectabilis ssp. } \\
\text { connatifolius (A. Nels.) Keck }\end{array}$ & desert beardtongue & $x$ & & & & $x$ \\
\hline & Penstemon thompsoniae (Gray) Rydb. & Thompson's beardtongue & $\mathrm{X}$ & & & & \\
\hline
\end{tabular}




\begin{tabular}{|c|c|c|c|c|c|c|c|}
\hline Family & Scientific name & Common name & $B \& R$ & Row & $H \& G$ & Mau & NPS \\
\hline \multirow[t]{3}{*}{ Scrophulariaceae } & Stemodia durantifolia (L.) Sw. & whitewoolly twintip & $x$ & & & & \\
\hline & Verbascum thapsus $\mathrm{L}$. & common mullein & & & $\mathrm{X}$ & $x$ & $\mathrm{X}$ \\
\hline & Veronica anagallis-aquatica L. & water speedwell & $x$ & & & & $x$ \\
\hline Simaroubaceae & Ailanthus altissima (P. Mill.) Swingle & tree of heaven & $\mathrm{x}$ & $\mathrm{X}$ & & & \\
\hline \multirow[t]{13}{*}{ Solanaceae } & Calibrachoa parviflora (Juss.) D'Arcy & seaside petunia & $x$ & & & & \\
\hline & Chamaesaracha coronopus (Dunal) Gray & greenleaf five eyes & $x$ & & & & $X$ \\
\hline & Datura wrightii Regel & sacred thorn-apple & $X$ & & & & \\
\hline & Lycium pallidum Miers & pale desert-thorn & $x$ & $X$ & & & $X$ \\
\hline & Nicotiana attenuata Torr. ex S. Wats. & coyote tobacco & $x$ & & & & \\
\hline & Nicotiana obtusifolia var. obtusifolia Merte & & & & & & \\
\hline & $\&$ Galeotti & desert tobacco & & $X$ & & & \\
\hline & $\begin{array}{l}\text { Nicotiana trigonophylla var. trigonophylla } \\
\text { Dunal }\end{array}$ & desert tobacco & $x$ & & & & \\
\hline & Physalis acutifolia (Miers) Sandw. & sharpleaf groundcherry & $x$ & $X$ & & & \\
\hline & Physalis hederifolia var. fendleri (Gray) & & & & & & \\
\hline & Cronq $\quad \ldots$ & Fendler's groundcherry & $x$ & & & & \\
\hline & Solanum douglasii Dunal & greenspot nightshade & $x$ & & & & \\
\hline & Solanum elaeagnifolium Cav. & silverleaf nightshade & $x$ & $x$ & & & \\
\hline Tamaricaceae & Tamarix ramosissima Ledeb. & saltcedar & $\mathrm{X}$ & $\mathrm{X}$ & & & \\
\hline Ulmaceae & $\begin{array}{l}\text { Celtis laevigata var. reticulata (Torr.) L. } \\
\text { Benson }\end{array}$ & netleaf hackberry & $x$ & $x$ & & & $x$ \\
\hline Urticaceae & Parietaria hespera Hinton & rillita pellitory & & & & & $x$ \\
\hline \multirow[t]{4}{*}{ Verbenaceae } & Aloysia wrightii Heller ex Abrams & Wright's beebrush & $x$ & $X$ & & & \\
\hline & Glandularia gooddingii (Briq.) Solbrig & southwestern mock vervain & $x$ & & & & \\
\hline & Glandularia wrightii (Gray) Umber & Davis Mountain mock vervain & $x$ & & & & \\
\hline & Tetraclea coulteri Gray & Coulter's wrinklefruit & $x$ & $x$ & & & \\
\hline Violaceae & Hybanthus verticillatus (Ortega) Baill. & babyslippers & $X$ & $X$ & & & \\
\hline Viscaceae & $\begin{array}{l}\text { Phoradendron tomentosum (DC.) Engelm. } \\
\text { ex Gray }\end{array}$ & Christmas mistletoe & $x$ & $X$ & & & \\
\hline Vitaceae & Vitis arizonica Engelm. & canyon grape & $x$ & $x$ & & & \\
\hline Zannichelliaceae & Zannichellia palustris L. & horned pondweed & $X$ & & & & \\
\hline \multirow[t]{6}{*}{ Zygophyllaceae } & Kallstroemia californica (S. Wats.) Vail & California caltrop & $x$ & & & & \\
\hline & Kallstroemia parviflora J.B.S. Norton & warty caltrop & $x$ & & & & \\
\hline & Larrea tridentata (Sessé \& Moc. ex DC.) & & & & & & \\
\hline & Coville & creosote bush & $x$ & & & & $x$ \\
\hline & $\begin{array}{l}\text { Larrea tridentata var. tridentata (Sessé \& } \\
\text { Moc. ex DC.) Coville }\end{array}$ & creosote bush & & $X$ & & & \\
\hline & Tribulus terrestris $\mathrm{L}$. & puncturevine & $\mathrm{X}$ & $\mathrm{X}$ & & & \\
\hline
\end{tabular}


Appendix B. Plant species observed or collected at Montezuma Castle NM, Well unit. Based on Brian and Rowlands (B\&R; 1994), Rowlands (Row; 1999), Halvorson and Guertin (H\&G; 2003), Mau-Crimmins et al. (Mau; 2004), and NPS (unpublished data). Species in bold-faced type are non-native.

\begin{tabular}{|c|c|c|c|c|c|c|c|}
\hline Family & Scientific name & Common name & B\&R & Row & $H \& G$ & Mau & NPS \\
\hline \multirow[t]{3}{*}{ Agavaceae } & Yucca elata (Engelm.) Engelm. & soaptree yucca & & $X$ & & & $X$ \\
\hline & Yucca elata var. verdiensis (McKelvey) & & & & & & \\
\hline & Reveal & Verdi yucca & $X$ & & & & \\
\hline \multirow[t]{4}{*}{ Anacardiaceae } & Rhus aromatica Ait. & fragrant sumac & & & & & $X$ \\
\hline & Rhus trilobata Nutt. & skunkbush sumac & $\mathrm{X}$ & $X$ & & & \\
\hline & Toxicodendron rydbergii (Small ex Rydb.) & & & & & & \\
\hline & Greene & western poison ivy & $X$ & & & & \\
\hline \multirow[t]{5}{*}{ Apiaceae } & Berula erecta (Huds.) Coville & cutleaf waterparsnip & $x$ & & & & \\
\hline & Cymopterus multinervatus (Coult. \& Rose) & & & & & & \\
\hline & Tidestrom & purplenerve springparsley & $x$ & & & & \\
\hline & Daucus pusillus Michx. & American wild carrot & $\mathrm{X}$ & & & & \\
\hline & Hydrocotyle verticillata Thunb. & whorled marshpennywort & $x$ & & & & \\
\hline Apocynaceae & Apocynum cannabinum $\mathrm{L}$. & Indianhemp & $x$ & & & & \\
\hline Asclepiadaceae & $\begin{array}{l}\text { Funastrum cynanchoides ssp. } \\
\text { cynanchoides (Dcne.) Schlechter }\end{array}$ & fringed twinevine & $X$ & $X$ & & & \\
\hline \multirow[t]{30}{*}{ Asteraceae } & Acourtia wrightii (Gray) Reveal \& King & brownfoot & $X$ & $X$ & & & $x$ \\
\hline & Ambrosia confertiflora DC. & weakleaf burr ragweed & $X$ & & & & \\
\hline & Ambrosia psilostachya DC. & Cuman ragweed & $X$ & & & & \\
\hline & Artemisia carruthii Wood ex Carruth. & Carruth's sagewort & $x$ & & & & \\
\hline & Artemisia ludoviciana Nutt. & white sagebrush & $x$ & $x$ & & & $x$ \\
\hline & Aster L. & aster & & & & & $x$ \\
\hline & Baccharis emoryi Gray & Emory's baccharis & $x$ & & & & $x$ \\
\hline & Baccharis salicifolia (Ruiz \& Pavón) Pers. & mule's fat & $x$ & $x$ & & & \\
\hline & Baccharis sarothroides Gray & desertbroom & $x$ & & & & \\
\hline & Bahia dissecta (Gray) Britt. & ragleaf bahia & $x$ & & & & \\
\hline & Baileya pleniradiata Harvey \& Gray ex Gray & woolly desert marigold & $x$ & & & & \\
\hline & Bidens laevis (L.) B.S.P. & smooth beggartick & $x$ & & & & \\
\hline & Brickellia atractyloides Gray & spearleaf brickellbush & $x$ & $x$ & & & \\
\hline & Brickellia californica (Torr. \& Gray) Gray & California brickellbush & $x$ & $x$ & & & \\
\hline & Brickellia floribunda Gray & Chihuahuan brickellbush & $x$ & & & & \\
\hline & Centaurea melitensis L. & Maltese star-thistle & $\mathrm{X}$ & $\mathbf{X}$ & $X$ & $\mathrm{X}$ & \\
\hline & Centaurea solstitialis L. & yellow star-thistle & & & & $\mathrm{X}$ & \\
\hline & Chaetopappa ericoides (Torr.) Nesom & rose heath & $x$ & $X$ & & & \\
\hline & Chloracantha spinosa (Benth.) Nesom & spiny chloracantha & $X$ & & & & \\
\hline & Cichorium intybus $\mathrm{L}$. & chicory & $\mathrm{X}$ & $\mathrm{X}$ & & & \\
\hline & Cirsium arizonicum (Gray) Petrak & Arizona thistle & $\mathrm{X}$ & & & & \\
\hline & Conyza canadensis (L.) Cronq. & Canadian horseweed & $X$ & & & $x$ & \\
\hline & Encelia farinosa Gray ex Torr. & goldenhills & & & & & $x$ \\
\hline & Encelia frutescens (Gray) Gray & button brittlebush & $x$ & & & & $x$ \\
\hline & Encelia virginensis A. Nels. & Virgin River brittlebush & $X$ & & & & \\
\hline & Erigeron concinnus (Hook. \& Arn.) Torr. & & & & & & \\
\hline & \& Gray & Navajo fleabane & $x$ & $x$ & & & \\
\hline & Erigeron divergens Torr. \& Gray & spreading fleabane & $x$ & & & & $x$ \\
\hline & Gaillardia pinnatifida Torr. & red dome blanketflower & $x$ & & & & \\
\hline & Gutierrezia microcephala (DC.) Gray & threadleaf snakeweed & $x$ & & & & \\
\hline
\end{tabular}




\begin{tabular}{|c|c|c|c|c|c|c|c|}
\hline $\begin{array}{l}\text { Family } \\
\end{array}$ & Scientific name & Common name & B\&R & Row & H\&G & Mau & NPS \\
\hline \multirow[t]{32}{*}{ Asteraceae } & Gutierrezia sarothrae (Pursh) Britt. \& & & & & & & \\
\hline & Rusby & broom snakeweed & $\mathrm{x}$ & $\mathrm{x}$ & & & $\mathrm{x}$ \\
\hline & Helianthus annuus $\mathrm{L}$. & common sunflower & $\mathrm{x}$ & & $\mathrm{x}$ & $x$ & \\
\hline & Heterotheca subaxillaris (Lam.) Britt. \& & & & & & & \\
\hline & Rusby & camphorweed & & $x$ & & $x$ & \\
\hline & Heterotheca villosa (Pursh) Shinners & hairy false goldenaster & $\mathrm{x}$ & & & & \\
\hline & Hymenoclea monogyra Torr. \& Gray ex Gray & singlewhorl burrobrush & $\mathrm{x}$ & $\mathrm{x}$ & & & \\
\hline & Hymenothrix loomisii Blake & Loomis' thimblehead & $\mathrm{x}$ & & & & \\
\hline & Lactuca saligna L. & willowleaf lettuce & $\mathbf{x}$ & & & & \\
\hline & Lactuca serriola L. & prickly lettuce & $\mathbf{x}$ & & $\mathbf{x}$ & $\mathbf{x}$ & \\
\hline & Melampodium leucanthum Torr. \& Gray & plains blackfoot & $\mathrm{x}$ & $\mathrm{x}$ & & & \\
\hline & $\begin{array}{l}\text { Packera neomexicana var. neomexicana } \\
\text { (Gray) W.A. Weber \& A. Löve }\end{array}$ & New Mexico groundsel & $\mathrm{x}$ & & & & \\
\hline & Parthenium incanum Kunth & mariola & $\mathrm{x}$ & $\mathrm{x}$ & & & $\mathrm{x}$ \\
\hline & Senecio flaccidus var. flaccidus Less. & threadleaf ragwort & $\mathrm{x}$ & $\mathrm{x}$ & & & \\
\hline & Solidago canadensis var. scabra Torr. & & & & & & \\
\hline & \& Gray & Canada goldenrod & $\mathrm{x}$ & & & & \\
\hline & Solidago velutina DC. & threenerve goldenrod & $\mathrm{x}$ & & & & \\
\hline & Solidago wrightii Gray & Wright's goldenrod & $\mathrm{x}$ & $\mathrm{x}$ & & & \\
\hline & Sonchus asper (L.) Hill & spiny sowthistle & $\mathrm{x}$ & $\mathrm{x}$ & & & \\
\hline & Stephanomeria minor var. minor (Hook.) & & & & & & \\
\hline & Nutt. & narrowleaf wirelettuce & $x$ & & & & \\
\hline & Stephanomeria pauciflora (Torr.) A. Nels. & brownplume wirelettuce & & $\mathrm{x}$ & & & \\
\hline & Symphyotrichum divaricatum (Nutt.) Nesom & southern annual saltmarsh aster & $\mathrm{x}$ & & & & \\
\hline & $\begin{array}{l}\text { Symphyotrichum falcatum var. falcatum } \\
\text { (Lindl.) Nesom }\end{array}$ & white prairie aster & $x$ & & & & \\
\hline & $\begin{array}{l}\text { Symphyotrichum praealtum var. praealtum } \\
\text { (Poir.) Nesom }\end{array}$ & willowleaf aster & $\mathrm{x}$ & & & & \\
\hline & Taraxacum laevigatum (Willd.) DC. & rock dandelion & & $\mathbf{x}$ & & & \\
\hline & Taraxacum officinale G.H. Weber ex & & & & & & \\
\hline & Wiggers & common dandelion & $\mathrm{x}$ & & & & \\
\hline & Tragopogon dubius Scop. & yellow salsify & $\mathbf{x}$ & $\mathbf{x}$ & & & \\
\hline & Uropappus lindleyi (DC.) Nutt. & Lindley's silverpuffs & $\mathrm{x}$ & & & & $\mathrm{x}$ \\
\hline & $\begin{array}{l}\text { Verbesina encelioides ssp. exauriculata } \\
\text { (Robins. \& Greenm.) J.R. Coleman }\end{array}$ & golden crownbeard & $\mathrm{x}$ & & & & \\
\hline & Xanthium strumarium L. & rough cockleburr & $\mathrm{x}$ & & $\mathrm{x}$ & $\mathrm{x}$ & \\
\hline Berberidaceae & Mahonia haematocarpa (Woot.) Fedde & red barberry & $\mathrm{x}$ & $\mathrm{x}$ & & & $\mathrm{x}$ \\
\hline Betulaceae & Alnus oblongifolia Torr. & Arizona alder & $x$ & $x$ & & & $\mathrm{x}$ \\
\hline Bignoniaceae & Chilopsis linearis (Cav.) Sweet & desert willow & & $x$ & & & \\
\hline & Chilopsis linearis ssp. arcuata (Fosberg) & & & & & & \\
\hline & Henrickson & desert willow & $x$ & & & & \\
\hline Boraginaceae & Amsinckia menziesii (Lehm.) A. Nels. \& & & & & & & \\
\hline & J.F. Macbr. & Menzies' fiddleneck & & & & & $\mathrm{x}$ \\
\hline & Cryptantha Lehm. ex G. Don & cryptantha & & & & & $\mathrm{x}$ \\
\hline Boraginaceae & Lappula occidentalis var. cupulata (Gray) & & & & & & \\
\hline & Higgins & flatspine stickseed & $\mathrm{x}$ & & & & \\
\hline & $\begin{array}{l}\text { Lappula occidentalis var. occidentalis } \\
\text { (S. Wats.) Greene }\end{array}$ & flatspine stickseed & $\mathrm{x}$ & & & & $\mathrm{x}$ \\
\hline & Lithospermum incisum Lehm. & narrowleaf stoneseed & $\mathrm{x}$ & $\mathrm{x}$ & & & \\
\hline Brassicaceae & Brassica tournefortii Gouan & Asian mustard & & & & $\mathrm{x}$ & \\
\hline
\end{tabular}




\begin{tabular}{|c|c|c|c|c|c|c|c|}
\hline Family & Scientific name & Common name & B\&R & Row & H\&G & Mau & NPS \\
\hline \multirow[t]{11}{*}{ Brassicaceae } & Capsella bursa-pastoris (L.) Medik. & shepherd's purse & $\mathbf{x}$ & $\mathbf{x}$ & & & \\
\hline & Descurainia pinnata (Walt.) Britt. & western tansymustard & $x$ & & & & $x$ \\
\hline & Descurainia sophia (L.) Webb ex Prantl & herb sophia & $x$ & $\mathbf{x}$ & $\mathbf{x}$ & & \\
\hline & Draba cuneifolia Nutt. ex Torr. \& Gray & wedgeleaf draba & $x$ & & & & \\
\hline & Lepidium lasiocarpum Nutt. & shaggyfruit pepperweed & $x$ & & & & $x$ \\
\hline & Lesquerella arizonica S. Wats. & Arizona bladderpod & $x$ & & & & \\
\hline & Lesquerella gordonii (Gray) S. Wats. & Gordon's bladderpod & $x$ & & & & \\
\hline & Lesquerella tenella A. Nels. & Moapa bladderpod & & & & & $x$ \\
\hline & Rorippa nasturtium-aquaticum (L.) Hayek & watercress & $x$ & $x$ & & & \\
\hline & Sisymbrium irio L. & London rocket & $x$ & $x$ & $x$ & $\mathbf{x}$ & $x$ \\
\hline & $\begin{array}{l}\text { Streptanthus carinatus ssp. arizonicus (S. } \\
\text { Wats.) Kruckeberg, Rodman \& Worthington }\end{array}$ & lyreleaf jewelflower & $x$ & & & & \\
\hline \multirow[t]{12}{*}{ Cactaceae } & $\begin{array}{l}\text { Echinocereus fendleri var. } \\
\text { boyce-thompsonii (Orcutt) L. Benson }\end{array}$ & Boyce Thompson hedgehog & tus X & & & & \\
\hline & $\begin{array}{l}\text { Echinocereus fendleri var. fasciculatus } \\
\text { (Engelm. ex B.D. Jackson) N.P. Taylor }\end{array}$ & pinkflower hedgehog cactus & & & & & $x$ \\
\hline & Escobaria vivipara var. arizonica (Engelm.) & & & & & & \\
\hline & D.R. Hunt & Arizona spinystar & $x$ & $x$ & & & \\
\hline & $\begin{array}{l}\text { Escobaria vivipara var. vivipara (Nutt.) } \\
\text { Buxbaum }\end{array}$ & spinystar & & & & & $x$ \\
\hline & $\begin{array}{l}\text { Opuntia engelmannii Salm-Dyck var. } \\
\text { engelmannii }\end{array}$ & cactus apple & $x$ & & & & \\
\hline & Opuntia leptocaulis DC. & Christmas cactus & $x$ & & & & $x$ \\
\hline & $\begin{array}{l}\text { Opuntia macrocentra var. macrocentra } \\
\text { Engelm. }\end{array}$ & purple pricklypear & $x$ & $\mathrm{X}$ & & & \\
\hline & Opuntia macrorhiza Engelm. & twistspine pricklypear & & & & & $x$ \\
\hline & $\begin{array}{l}\text { Opuntia macrorhiza Engelm. var. } \\
\text { macrorhiza }\end{array}$ & twistspine pricklypear & & $x$ & & & \\
\hline & Opuntia phaeacantha Engelm. & tulip pricklypear & & $x$ & & & $X$ \\
\hline & Opuntia phaeacantha var. major Engelm. & Mojave pricklypear & $X$ & & & & \\
\hline Campanulaceae & Lobelia cardinalis L. & cardinalflower & $x$ & & & & \\
\hline \multirow[t]{2}{*}{ Capparaceae } & Cleome lutea var. jonesii J.F. Macbr. & Jones spiderflower & $x$ & & & & \\
\hline & $\begin{array}{l}\text { Polanisia dodecandra ssp. trachysperma } \\
\text { (Torr. \& Gray) Iltis }\end{array}$ & sandyseed clammyweed & $x$ & & & & \\
\hline Caryophyllaceae & Silene antirrhina $\mathrm{L}$. & sleepy silene & & & & & $x$ \\
\hline Celastraceae & Canotia holacantha Torr. & crucifixion thorn & $x$ & & & & \\
\hline \multirow[t]{5}{*}{ Chenopodiaceae } & Atriplex canescens (Pursh) Nutt. & fourwing saltbush & $x$ & $x$ & & & \\
\hline & $\begin{array}{l}\text { Chenopodium berlandieri var. sinuatum } \\
\text { (J. Murr) H.A. Wahl }\end{array}$ & pitseed goosefoot & $x$ & & & & \\
\hline & Chenopodium fremontii S. Wats. & Fremont's goosefoot & $x$ & & & & \\
\hline & $\begin{array}{l}\text { Krascheninnikovia lanata (Pursh) A.D.J. } \\
\text { Meeuse \& Smit }\end{array}$ & winterfat & $x$ & $x$ & & & \\
\hline & Salsola tragus $\mathrm{L}$. & prickly Russian thistle & $\mathbf{x}$ & $x$ & & & \\
\hline \multirow[t]{3}{*}{ Convolvulaceae } & Convolvulus arvensis $\mathrm{L}$. & field bindweed & $\mathbf{X}$ & $\mathbf{X}$ & & & $\mathbf{X}$ \\
\hline & Convolvulus equitans Benth. & Texas bindweed & $x$ & & & & \\
\hline & Ipomoea hederacea Jacq. & ivyleaf morning-glory & $x$ & 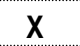 & & & \\
\hline Cucurbitaceae & Cucurbita foetidissima Kunth & Missouri gourd & $x$ & $x$ & & & \\
\hline Cupressaceae & $\begin{array}{l}\text { Juniperus coahuilensis (Martinez) Gaussen } \\
\text { ex R.P. Adams }\end{array}$ & redberry juniper & $x$ & & & & \\
\hline
\end{tabular}




\begin{tabular}{|c|c|c|c|c|c|c|c|}
\hline Family & Scientific name & Common name & B\&R & Row & H\&G & Mau & NPS \\
\hline \multirow[t]{2}{*}{ Cupressaceae } & Juniperus monosperma (Engelm.) Sarg. & oneseed juniper & $\mathrm{x}$ & $\mathrm{x}$ & & & $\mathrm{X}$ \\
\hline & Juniperus osteosperma (Torr.) Little & Utah juniper & $\mathrm{x}$ & $\mathrm{x}$ & & & $\mathrm{x}$ \\
\hline \multirow{6}{*}{ Cyperaceae } & Cyperus esculentus $\mathrm{L}$. & chufa flatsedge & $\mathrm{x}$ & & $\mathrm{X}$ & $\mathrm{X}$ & \\
\hline & Cyperus niger Ruiz \& Pavón & black flatsedge & $\mathrm{x}$ & & & & \\
\hline & Eleocharis parishii Britt. & Parish's spikerush & $\mathrm{x}$ & & & & \\
\hline & Eleocharis rostellata (Torr.) Torr. & beaked spikerush & $\mathrm{x}$ & & & & \\
\hline & Schoenoplectus tabernaemontani (K.C. & & & & & & \\
\hline & Gmel.) Palla & softstem bulrush & $\mathrm{x}$ & & & & \\
\hline Ephedraceae & Ephedra viridis Coville & mormon tea & $\mathrm{x}$ & $\mathrm{x}$ & & & $\mathrm{X}$ \\
\hline \multirow[t]{2}{*}{ Equisetaceae } & Equisetum hyemale var. affine (Engelm.) & & & & & & \\
\hline & A.A. Eat. & scouringrush horsetail & $\mathrm{X}$ & & & & \\
\hline \multirow[t]{12}{*}{ Euphorbiaceae } & Acalypha neomexicana Muell.-Arg. & New Mexico copperleaf & $\mathrm{x}$ & & & & \\
\hline & Chamaesyce albomarginata (Torr. \& Gray) & & & & & & \\
\hline & Small & whitemargin sandmat & $\mathrm{x}$ & & & & \\
\hline & Chamaesyce capitellata (Engelm.) Millsp. & head sandmat & $\mathrm{x}$ & & & & \\
\hline & Chamaesyce chaetocalyx (Boiss.) Woot. & & & & & & \\
\hline & \& Standl. var. chaetocalyx & bristlecup sandmat & $\mathrm{X}$ & & & & \\
\hline & Chamaesyce fendleri (Torr. \& Gray) Small & Fendler's sandmat & $\mathrm{x}$ & & & & \\
\hline & Chamaesyce maculata (L.) Small & spotted sandmat & $\mathrm{x}$ & & & & \\
\hline & Chamaesyce serpyllifolia ssp. serpyllifolia & & & & & & \\
\hline & (Pers.) Small & thymeleaf sandmat & $\mathrm{x}$ & & & & \\
\hline & Euphorbia brachycera Engelm. & horned spurge & $\mathrm{x}$ & & & & \\
\hline & Tragia ramosa Torr. & branched noseburn & $\mathrm{x}$ & & & & \\
\hline \multirow[t]{12}{*}{ Fabaceae } & Acacia greggii Gray & catclaw acacia & $\mathrm{x}$ & $\mathrm{x}$ & & & $\mathrm{x}$ \\
\hline & Amorpha fruticosa $\mathrm{L}$. & desert false indigo & $\mathrm{x}$ & $\mathrm{x}$ & & & \\
\hline & Astragalus calycosus Torr. ex S. Wats. & Torrey's milkvetch & & $\mathrm{x}$ & & & $\mathrm{x}$ \\
\hline & Astragalus calycosus var. scaposus (Gray) & & & & & & \\
\hline & M.E. Jones & Torrey's milkvetch & $\mathrm{x}$ & & & & $\mathrm{x}$ \\
\hline & Astragalus Ientiginosus Dougl. ex Hook. & freckled milkvetch & & $\mathrm{x}$ & & & \\
\hline & $\begin{array}{l}\text { Astragalus lentiginosus var. diphysus } \\
\text { (Gray) M.E. Jones }\end{array}$ & freckled milkvetch & $\mathrm{x}$ & & & & \\
\hline & $\begin{array}{l}\text { Astragalus lentiginosus var. palans } \\
\text { (M.E. Jones) M.E. Jones }\end{array}$ & freckled milkvetch & $\mathrm{x}$ & & & & \\
\hline & Astragalus nuttallianus DC. & smallflowered milkvetch & $x$ & & & & $\mathrm{x}$ \\
\hline & $\begin{array}{l}\text { Astragalus tephrodes var. brachylobus } \\
\text { (Gray) Barneby }\end{array}$ & ashen milkvetch & $\mathrm{x}$ & & & & \\
\hline & Caesalpinia drepanocarpa (Gray) Fisher & sicklepod holdback & $x$ & $x$ & & & \\
\hline & Calliandra humilis Benth. & dwarf stickpea & & & & & $\mathrm{X}$ \\
\hline \multirow[t]{11}{*}{ Fabaceae } & Dalea formosa Torr. & featherplume & $\mathrm{x}$ & $\mathrm{x}$ & & & \\
\hline & Desmanthus cooleyi (Eat.) Trel. & Cooley's bundleflower & $\mathrm{x}$ & & & & \\
\hline & Hoffmannseggia glauca (Ortega) Eifert & Indian rushpea & $x$ & & & & \\
\hline & Lotus corniculatus $\mathrm{L}$. & birdfoot deervetch & $\mathrm{x}$ & $\mathrm{X}$ & & & \\
\hline & Lotus mearnsii (Britt.) Greene & Mearns' bird's-foot trefoil & $\mathrm{x}$ & & & & \\
\hline & Lupinus brevicaulis S. Wats. & shortstem lupine & $\mathrm{x}$ & & & & \\
\hline & Medicago polymorpha L. & burclover & $\mathrm{x}$ & $\mathrm{X}$ & & & \\
\hline & Medicago sativa L. & alfalfa & $\mathrm{x}$ & $\mathrm{x}$ & & & \\
\hline & Melilotus indicus (L.) All. & annual yellow sweetclover & $\mathbf{x}$ & $\mathbf{x}$ & $\mathrm{x}$ & $\mathbf{x}$ & \\
\hline & Melilotus officinalis (L.) Lam. & yellow sweetclover & $\mathbf{x}$ & $\mathbf{x}$ & $\mathrm{x}$ & $\mathrm{x}$ & \\
\hline & Mimosa aculeaticarpa Ortega & catclaw mimosa & & & & & $\mathrm{x}$ \\
\hline
\end{tabular}




\begin{tabular}{|c|c|c|c|c|c|c|c|}
\hline Family & Scientific name & Common name & B\&R & Row & H\&G & Mau & NPS \\
\hline \multirow[t]{5}{*}{ Fabaceae } & $\begin{array}{l}\text { Mimosa aculeaticarpa var. biuncifera } \\
\text { (Benth.) Barneby }\end{array}$ & catclaw mimosa & $X$ & $X$ & & & \\
\hline & Phaseolus angustissimus Gray & slimleaf bean & $x$ & $x$ & & & \\
\hline & Prosopis velutina Woot. & velvet mesquite & $x$ & $x$ & & & $x$ \\
\hline & Senna bauhinioides (Gray) Irwin \& Barneby & twinleaf senna & $x$ & & & & \\
\hline & Vicia ludoviciana Nutt. & Louisiana vetch & $x$ & & & & \\
\hline Fagaceae & Quercus turbinella Greene & Sonoran scrub oak & $x$ & $x$ & & & \\
\hline \multirow[t]{2}{*}{ Fumariaceae } & Corydalis aurea Willd. & scrambled eggs & $x$ & & & & $x$ \\
\hline & $\begin{array}{l}\text { Corydalis curvisiliqua ssp. occidentalis } \\
\text { (Engelm. ex Gray) W.A. Weber }\end{array}$ & curvepod fumewort & $x$ & & & & \\
\hline \multirow[t]{2}{*}{ Geraniaceae } & Erodium cicutarium (L.) L'Hér. ex Ait. & redstem stork's bill & $x$ & $x$ & $x$ & $x$ & $\mathbf{x}$ \\
\hline & Erodium texanum Gray & Texas stork's bill & $x$ & & & & $x$ \\
\hline Grossulariaceae & Ribes aureum Pursh & golden currant & $x$ & & & & \\
\hline \multirow[t]{4}{*}{ Hydrophyllaceae } & $\begin{array}{l}\text { Eucrypta chrysanthemifolia var. bipinnatifida } \\
\text { (Torr.) Constance }\end{array}$ & spotted hideseed & $x$ & & & & \\
\hline & Eucrypta micrantha (Torr.) Heller & dainty desert hideseed & $x$ & & & & \\
\hline & Phacelia crenulata Torr. ex S. Wats. & cleftleaf wildheliotrope & $x$ & & & & \\
\hline & Phacelia rotundifolia Torr. ex S. Wats. & roundleaf phacelia & $x$ & & & & \\
\hline Juglandaceae & Juglans major (Torr.) Heller & Arizona walnut & $x$ & $x$ & & & \\
\hline Juncaceae & Juncus xiphioides E. Mey. & irisleaf rush & $x$ & & & & \\
\hline Krameriaceae & Krameria erecta Willd. ex J.A. Schultes & littleleaf ratany & $x$ & $x$ & & & $x$ \\
\hline \multirow[t]{5}{*}{ Lamiaceae } & Hedeoma drummondii Benth. & Drummond's false pennyroyal & $x$ & & & & \\
\hline & Lamium amplexicaule L. & henbit deadnettle & & & & & $\mathbf{x}$ \\
\hline & Marrubium vulgare L. & horehound & $x$ & $\mathbf{x}$ & $\mathbf{x}$ & $\mathbf{X}$ & $\mathbf{x}$ \\
\hline & Mentha spicata L. & spearmint & $\mathrm{X}$ & $\mathbf{x}$ & & & \\
\hline & Salvia reflexa Hornem. & lanceleaf sage & $x$ & & & & \\
\hline \multirow[t]{2}{*}{ Liliaceae } & Calochortus flexuosus S. Wats. & winding mariposa lily & $x$ & & & & \\
\hline & $\begin{array}{l}\text { Dichelostemma capitatum (Benth.) Wood } \\
\text { ssp. capitatum }\end{array}$ & bluedicks & $x$ & & & & $x$ \\
\hline \multirow[t]{2}{*}{ Linaceae } & Linum lewisii Pursh & prairie flax & $x$ & & & & \\
\hline & Linum puberulum (Engelm.) Heller & plains flax & $x$ & & & & \\
\hline Loasaceae & $\begin{array}{l}\text { Mentzelia multiflora (Nutt.) Gray var. } \\
\text { multiflora }\end{array}$ & Adonis blazingstar & $x$ & & & & \\
\hline Lythraceae & Lythrum californicum Torr. \& Gray & California loosestrife & $x$ & $X$ & & & \\
\hline \multirow[t]{9}{*}{ Malvaceae } & Abutilon parvulum Gray & dwarf Indian mallow & $x$ & & & & \\
\hline & Malva neglecta Wallr. & common mallow & $\mathrm{X}$ & $\mathbf{x}$ & & & \\
\hline & Malva parviflora L. & cheeseweed mallow & & & $\mathbf{x}$ & & \\
\hline & Sida abutifolia P. Mill. & spreading fanpetals & $\mathbf{X}$ & & & & \\
\hline & Sphaeralcea ambigua Gray & desert globemallow & $x$ & $X$ & & & \\
\hline & Sphaeralcea grossulariifolia (Hook. \& Arn.) & & & & & & \\
\hline & Rydb. & gooseberryleaf globemallow & $x$ & & & & \\
\hline & Sphaeralcea parvifolia A. Nels. & smallflower globemallow & $x$ & & & & \\
\hline & Sphaeralcea rusbyi Gray & Rusby's globemallow & $x$ & & & & \\
\hline Moraceae & Morus microphylla Buckl. & Texas mulberry & $x$ & & & & \\
\hline \multirow[t]{6}{*}{ Nyctaginaceae } & Allionia incarnata L. & trailing windmills & $x$ & $x$ & & & \\
\hline & Boerhavia coccinea P. Mill. & scarlet spiderling & $x$ & & $x$ & $X$ & \\
\hline & Boerhavia erecta $L$. & erect spiderling & $x$ & & & & \\
\hline & Mirabilis bigelovii Gray & wishbone-bush & $x$ & & & & \\
\hline & Mirabilis multiflora (Torr.) Gray & Colorado four o'clock & & $x$ & & & \\
\hline & Mirabilis multiflora (Torr.) Gray var. multiflora & Colorado four o'clock & $x$ & & & & \\
\hline
\end{tabular}




\begin{tabular}{|c|c|c|c|c|c|c|c|}
\hline Family & Scientific name & Common name & B\&R & Row & H\&G & Mau & NPS \\
\hline Nyctaginaceae & Mirabilis pumila (Standl.) Standl. & dwarf four o'clock & & $X$ & & & \\
\hline \multirow[t]{2}{*}{ Oleaceae } & Fraxinus velutina Torr. & velvet ash & $x$ & $x$ & & & $x$ \\
\hline & Menodora scabra Gray & rough menodora & $x$ & $x$ & & & \\
\hline \multirow[t]{5}{*}{ Onagraceae } & Gaura coccinea Nutt. ex Pursh & scarlet beeblossom & $x$ & & & & \\
\hline & Gaura mollis James & velvetweed & $X$ & & & & \\
\hline & Oenothera albicaulis Pursh & whitest evening-primrose & $X$ & & & & $X$ \\
\hline & $\begin{array}{l}\text { Oenothera caespitosa ssp. marginata (Nutt. } \\
\text { ex Hook. \& Arn.) Munz }\end{array}$ & tufted evening-primrose & $x$ & & & & \\
\hline & $\begin{array}{l}\text { Oenothera elata ssp. hirsutissima (Gray ex } \\
\text { S. Wats.) W. Dietr. }\end{array}$ & Hooker's evening-primrose & $x$ & & & & \\
\hline Orchidaceae & Epipactis gigantea Dougl. ex Hook. & stream orchid & $x$ & & & & \\
\hline Papaveraceae & $\begin{array}{l}\text { Argemone polyanthemos (Fedde) G.B. } \\
\text { Ownbey }\end{array}$ & crested pricklypoppy & $x$ & $x$ & & & \\
\hline \multirow[t]{3}{*}{ Plantaginaceae } & Plantago lanceolata $\mathrm{L}$. & narrowleaf plantain & $\mathrm{X}$ & $\mathrm{X}$ & & & $\mathrm{X}$ \\
\hline & Plantago major $\mathrm{L}$. & common plantain & $x$ & $x$ & & & \\
\hline & Plantago patagonica Jacq. & woolly plantain & $x$ & & & & \\
\hline Platanaceae & Platanus wrightii S. Wats. & Arizona sycamore & $X$ & $X$ & & & $X$ \\
\hline \multirow[t]{31}{*}{ Poaceae } & Agrostis stolonifera L. & creeping bentgrass & $X$ & $x$ & & & \\
\hline & Aristida pansa Woot. \& Standl. & Wooton's threeawn & & & & & $\mathrm{X}$ \\
\hline & Aristida purpurea Nutt. & purple threeawn & $x$ & $x$ & & & $x$ \\
\hline & $\begin{array}{l}\text { Aristida purpurea var. Iongiseta (Steud.) } \\
\text { Vasey }\end{array}$ & Fendler threeawn & $x$ & & & & \\
\hline & Aristida purpurea var. nealleyi (Vasey) Allre & dblue threeawn & $x$ & & & & \\
\hline & Aristida ternipes Cav. & spidergrass & $x$ & & & & \\
\hline & Avena fatua $L$. & wild oat & $\mathrm{x}$ & $\mathrm{X}$ & $\mathrm{X}$ & $\mathrm{X}$ & \\
\hline & Bothriochloa barbinodis (Lag.) Herter & cane bluestem & $x$ & & & & \\
\hline & Bouteloua aristidoides (Kunth) Griseb. & needle grama & $x$ & & & & \\
\hline & Bouteloua curtipendula (Michx.) Torr. & sideoats grama & $X$ & $X$ & & & \\
\hline & Bouteloua eriopoda (Torr.) Torr. & black grama & $x$ & $\mathrm{X}$ & & & $x$ \\
\hline & Bromus anomalus Rupr. ex Fourn. & nodding brome & $x$ & & & & \\
\hline & Bromus carinatus Hook. \& Arn. & California brome & & & $x$ & & \\
\hline & Bromus catharticus Vahl & rescuegrass & & & $\mathrm{X}$ & & \\
\hline & Bromus diandrus Roth & ripgut brome & & & $\mathrm{X}$ & & $\mathrm{X}$ \\
\hline & Bromus inermis Leyss. & smooth brome & $\mathrm{X}$ & & & & \\
\hline & Bromus rigidus Roth & ripgut brome & $\mathrm{X}$ & $\mathrm{X}$ & & $\mathrm{X}$ & \\
\hline & Bromus rubens $\mathrm{L}$. & red brome & $\mathrm{X}$ & $\mathrm{X}$ & $\mathrm{X}$ & $\mathrm{X}$ & $\mathrm{X}$ \\
\hline & Bromus tectorum L. & cheatgrass & $\mathrm{X}$ & $\mathrm{X}$ & $\mathrm{X}$ & $\mathrm{X}$ & \\
\hline & Cenchrus spinifex Cav. & coastal sandbur & $x$ & & & & \\
\hline & Chloris virgata Sw. & feather fingergrass & & & $X$ & & \\
\hline & Cynodon dactylon (L.) Pers. & Bermudagrass & $x$ & $\mathrm{X}$ & $\mathrm{X}$ & $x$ & $x$ \\
\hline & Digitaria californica (Benth.) Henr. & Arizona cottontop & & & & & $x$ \\
\hline & Digitaria sanguinalis (L.) Scop. & hairy crabgrass & & & & $X$ & \\
\hline & Echinochloa colona (L.) Link & jungle rice & & & $\mathrm{X}$ & & \\
\hline & Echinochloa crus-galli (L.) Beauv. & barnyardgrass & & $X$ & $\mathbf{X}$ & $\mathrm{X}$ & \\
\hline & Elymus elymoides ssp. elymoides (Raf.) & & & & & & \\
\hline & Swezey & squirreltail & $x$ & $X$ & & & \\
\hline & Elymus glaucus Buckl. & blue wildrye & $x$ & & & & \\
\hline & $\begin{array}{l}\text { Elymus trachycaulus ssp. subsecundus } \\
\text { (Link) A.\& D. Löve }\end{array}$ & slender wheatgrass & $X$ & & & & \\
\hline & Enneapogon desvauxii Desv. ex Beauv. & nineawn pappusgrass & $X$ & & & & \\
\hline
\end{tabular}




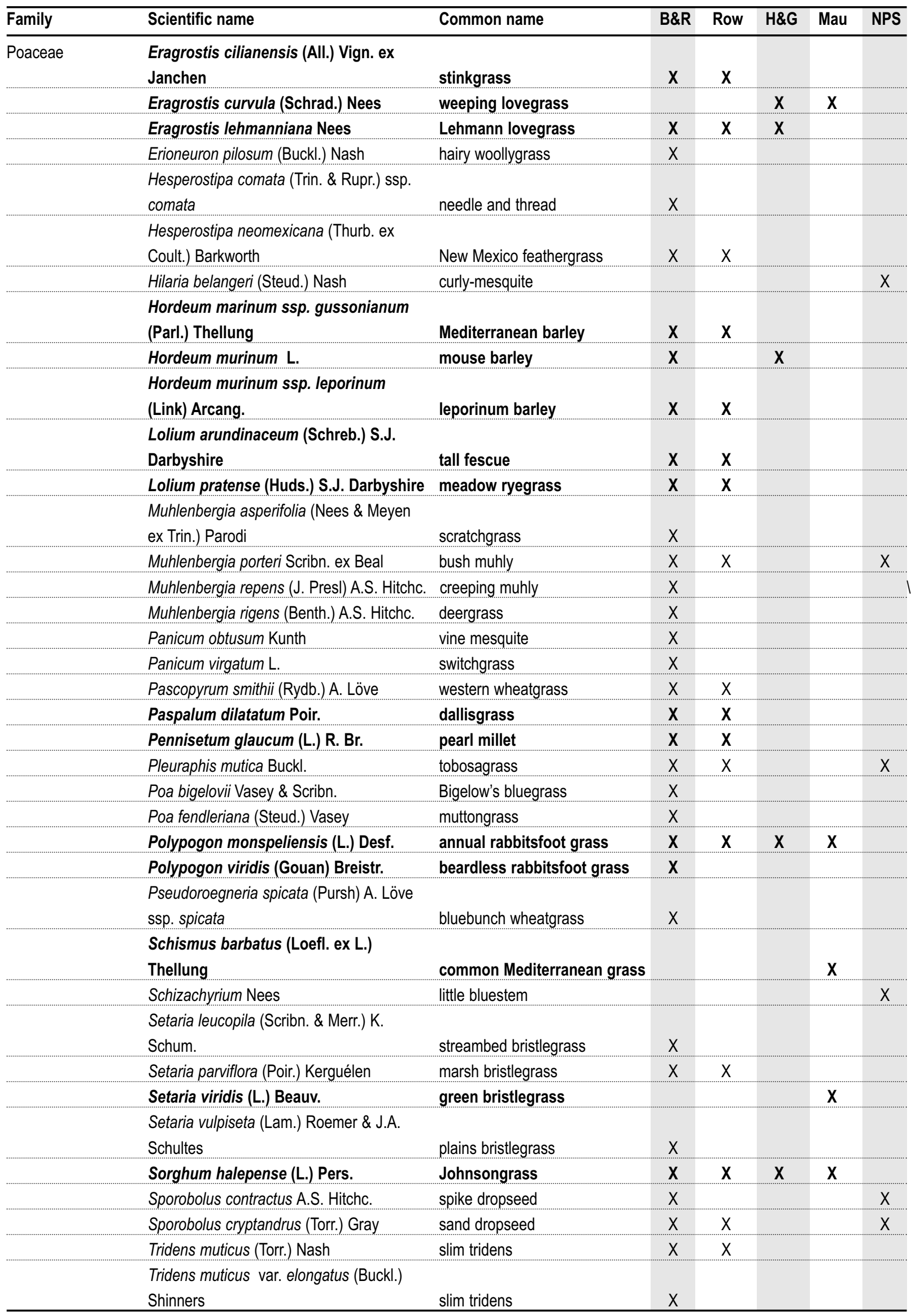




\begin{tabular}{|c|c|c|c|c|c|c|c|}
\hline Family & Scientific name & Common name & B\&R & Row & H\&G & Mau & NPS \\
\hline \multirow[t]{5}{*}{ Polemoniaceae } & Eriastrum eremicum (Jepson) Mason & desert woollystar & $X$ & & & & \\
\hline & Gilia sinuata Dougl. ex Benth. & rosy gilia & $x$ & & & & \\
\hline & Ipomopsis longiflora (Torr.) V. Grant & flaxflowered ipomopsis & $x$ & & & & \\
\hline & Phlox speciosa ssp. woodhousei (Torr. ex & & & & & & \\
\hline & Gray) Wherry & Woodhouse's phlox & $X$ & & & & \\
\hline \multirow[t]{2}{*}{ Polygalaceae } & Polygala rusbyi Greene & Rusby's milkwort & $X$ & & & & \\
\hline & Polygala scoparioides Chod. & broom milkwort & $X$ & & & & \\
\hline \multirow[t]{8}{*}{ Polygonaceae } & Eriogonum abertianum Torr. var. abertianun & $n$ Abert's buckwheat & $x$ & & & & \\
\hline & $\begin{array}{l}\text { Eriogonum microthecum var. simpsonii } \\
\text { (Benth.) Reveal }\end{array}$ & Simpson's buckwheat & $x$ & $x$ & & & \\
\hline & Eriogonum wrightii Torr. ex Benth. & bastardsage & & $\mathrm{X}$ & & & \\
\hline & $\begin{array}{l}\text { Eriogonum wrightii var. wrightii Torr. ex } \\
\text { Benth. }\end{array}$ & bastardsage & $x$ & & & & \\
\hline & Polygonum aviculare $\mathrm{L}$. & prostrate knotweed & & & $X$ & & \\
\hline & Polygonum punctatum Ell. & dotted smartweed & $x$ & & & & \\
\hline & Rumex crispus L. & curly dock & $\mathrm{X}$ & $\mathrm{X}$ & & $\mathrm{X}$ & \\
\hline & Rumex hymenosepalus Torr. & canaigre dock & $\mathrm{X}$ & & & & \\
\hline Portulacaceae & $\begin{array}{l}\text { Claytonia perfoliata ssp. perfoliata Donn } \\
\text { ex Willd. }\end{array}$ & miner's lettuce & $x$ & & & & \\
\hline \multirow[t]{3}{*}{ Potamogetonaceae } & Potamogeton gramineus $\mathrm{L}$. & variableleaf pondweed & $X$ & & & & \\
\hline & Potamogeton nodosus Poir. & longleaf pondweed & $x$ & & & & \\
\hline & Stuckenia pectinatus (L.) Boerner & sago pondweed & $x$ & & & & \\
\hline \multirow[t]{2}{*}{ Primulaceae } & Samolus valerandi ssp. parviflorus (Raf.) & & & & & & \\
\hline & Hultén & seaside brookweed & $x$ & & & & \\
\hline \multirow[t]{4}{*}{ Pteridaceae } & Adiantum capillus-veneris $\mathrm{L}$. & common maidenhair & $X$ & & & & \\
\hline & Astrolepis integerrima (Hook.) Benham \& & & & & & & \\
\hline & Windham & hybrid cloakfern & $x$ & & & & \\
\hline & Cheilanthes feei T. Moore & slender lipfern & $x$ & & & & \\
\hline \multirow[t]{4}{*}{ Ranunculaceae } & Anemone tuberosa Rydb. & tuber anemone & $x$ & & & & $x$ \\
\hline & Aquilegia chrysantha Gray & golden columbine & $x$ & $x$ & & & \\
\hline & Clematis ligusticifolia Nutt. & western white clematis & $x$ & & & & \\
\hline & Delphinium scaposum Greene & tall mountain larkspur & $x$ & $X$ & & & \\
\hline \multirow[t]{7}{*}{ Rhamnaceae } & $\begin{array}{l}\text { Frangula californica ssp. californica } \\
\text { (Eschsch.) Gray }\end{array}$ & California buckthorn & & $X$ & & & $x$ \\
\hline & Frangula californica ssp. ursina (Greene) & & & & & & \\
\hline & Kartesz \& Gandhi & California buckthorn & $x$ & & & & \\
\hline & Ziziphus obtusifolia (Hook. ex Torr. \& Gray) & & & & & & \\
\hline & 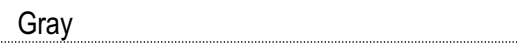 & lotebush & & $X$ & & & $X$ \\
\hline & Ziziphus obtusifolia var. canescens (Gray) & & & & & & \\
\hline & M.C. Johnston & lotebush & $x$ & & & & \\
\hline \multirow[t]{4}{*}{ Rosaceae } & Purshia mexicana (D. Don) Henrickson & Mexican cliffrose & & & & & \\
\hline & Purshia stansburiana (Torr.) Henrickson & Stansbury cliffrose & $x$ & & & & \\
\hline & Rubus arizonensis Focke & Arizona dewberry & $x$ & & & & \\
\hline & Rubus discolor Weihe \& Nees & Himalayan blackberry & $\mathrm{X}$ & $\mathrm{X}$ & & & \\
\hline \multirow[t]{2}{*}{ Rubiaceae } & Galium aparine $\mathrm{L}$. & stickywilly & $x$ & $\mathrm{X}$ & & & \\
\hline & Galium microphyllum Gray & bracted bedstraw & $X$ & & & & \\
\hline Rutaceae & Thamnosma texana (Gray) Torr. & rue of the mountains & $X$ & & & & \\
\hline \multirow[t]{3}{*}{ Salicaceae } & Populus fremontii S. Wats. & Fremont cottonwood & & $x$ & & & \\
\hline & Populus fremontii S. Wats. ssp. fremontii & Fremont cottonwood & $X$ & & & & \\
\hline & Salix bonplandiana Kunth & Bonpland willow & $x$ & & & & \\
\hline
\end{tabular}




\begin{tabular}{|c|c|c|c|c|c|c|c|}
\hline Family & Scientific name & Common name & B\&R & Row & H\&G & Mau & NPS \\
\hline \multirow[t]{2}{*}{ Salicaceae } & Salix exigua Nutt. & narrowleaf willow & $\mathrm{X}$ & & & & \\
\hline & Salix gooddingii Ball & Goodding's willow & $x$ & $x$ & & & \\
\hline \multirow[t]{3}{*}{ Sapindaceae } & Sapindus saponaria L. & wingleaf soapberry & & $x$ & & & \\
\hline & Sapindus saponaria var. drummondii (Hook & & & & & & \\
\hline & \& Arn.) L. Benson & western soapberry & $x$ & & & & \\
\hline \multirow[t]{9}{*}{ Scrophulariaceae } & Castilleja applegatei ssp. martinii (Abrams) & & & & & & \\
\hline & Chuang \& Heckard & wavyleaf Indian paintbrush & $x$ & & & & \\
\hline & Cordylanthus laxiflorus Gray & nodding bird's-beak & $x$ & & & & \\
\hline & Mimulus guttatus DC. & seep monkeyflower & $x$ & & & & \\
\hline & Mimulus rubellus Gray & little redstem monkeyflower & $x$ & & & & \\
\hline & $\begin{array}{l}\text { Penstemon eatonii ssp. undosus (M.E. } \\
\text { Jones) Keck }\end{array}$ & Eaton's penstemon & $x$ & & & & \\
\hline & Penstemon pseudospectabilis M.E. Jones & desert penstemon & & $X$ & & & $x$ \\
\hline & $\begin{array}{l}\text { Penstemon pseudospectabilis ssp. } \\
\text { connatifolius (A. Nels.) Keck }\end{array}$ & desert beardtongue & $x$ & & & & \\
\hline & Verbascum thapsus $\mathrm{L}$. & common mullein & $x$ & $\mathrm{X}$ & 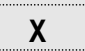 & $\mathrm{X}$ & \\
\hline Simaroubaceae & Ailanthus altissima (P. Mill.) Swingle & tree of heaven & $\mathrm{X}$ & $\mathrm{X}$ & & & \\
\hline \multirow[t]{6}{*}{ Solanaceae } & Chamaesaracha coronopus (Dunal) Gray & greenleaf five eyes & $x$ & & & & \\
\hline & Datura inoxia P. Mill. & pricklyburr & $\mathrm{X}$ & $\mathrm{X}$ & & & \\
\hline & Lycium pallidum Miers & pale desert-thorn & $\mathrm{x}$ & $x$ & & & \\
\hline & $\begin{array}{l}\text { Nicotiana obtusifolia var. obtusifolia } \\
\text { Mertens \& Galeotti }\end{array}$ & desert tobacco & & $X$ & & & \\
\hline & $\begin{array}{l}\text { Nicotiana trigonophylla var. trigonophylla } \\
\text { Dunal }\end{array}$ & desert tobacco & $x$ & & & & \\
\hline & Solanum elaeagnifolium Cav. & silverleaf nightshade & $x$ & $x$ & & & \\
\hline Tamaricaceae & Tamarix ramosissima Ledeb. & saltcedar & $\mathbf{X}$ & $\mathbf{X}$ & & & \\
\hline Typhaceae & Typha latifolia L. & broadleaf cattail & $x$ & & & & \\
\hline Ulmaceae & $\begin{array}{l}\text { Celtis laevigata var. reticulata (Torr.) L. } \\
\text { Benson }\end{array}$ & netleaf hackberry & $x$ & $x$ & & & $x$ \\
\hline \multirow[t]{2}{*}{ Urticaceae } & Parietaria hespera Hinton & rillita pellitory & $x$ & & & & $x$ \\
\hline & Parietaria pensylvanica Muhl. ex Willd. & Pennsylvania pellitory & $x$ & & & & $x$ \\
\hline \multirow[t]{4}{*}{ Verbenaceae } & Aloysia wrightii Heller ex Abrams & Wright's beebrush & $x$ & & & & \\
\hline & $\begin{array}{l}\text { Glandularia bipinnatifida var. bipinnatifida } \\
\text { (Nutt.) Nutt. }\end{array}$ & Dakota mock vervain & $x$ & & & & \\
\hline & Glandularia gooddingii (Briq.) Solbrig & southwestern mock vervain & $x$ & $x$ & & & $x$ \\
\hline & Verbena bracteata Lag. \& Rodr. & bigbract verbena & $x$ & & & & \\
\hline \multirow[t]{2}{*}{ Vitaceae } & Parthenocissus vitacea (Knerr) A.S. Hitchc. & woodbine & $x$ & $x$ & & & \\
\hline & Vitis arizonica Engelm. & canyon grape & $x$ & $x$ & & & $x$ \\
\hline Zannichelliaceae & Zannichellia palustris L. & horned pondweed & $x$ & & & & \\
\hline \multirow[t]{5}{*}{ Zygophyllaceae } & Kallstroemia californica (S. Wats.) Vail & California caltrop & $x$ & & & & \\
\hline & Larrea tridentata (Sessé \& Moc. ex DC.) & & & & & & \\
\hline & Coville & creosote bush & & & & & $x$ \\
\hline & $\begin{array}{l}\text { Larrea tridentata var. tridentata (Sessé \& } \\
\text { Moc. ex DC.) Coville }\end{array}$ & creosote bush & $x$ & $X$ & & & \\
\hline & Tribulus terrestris $\mathrm{L}$. & puncturevine & $x$ & $x$ & & $\mathbf{X}$ & \\
\hline
\end{tabular}


Appendix C. Fish species observed or collected at Montezuma Castle NM. Based on Montgomery et al. $(1995,1996)$. Species in bold-faced type are non-native.

\begin{tabular}{|c|c|c|c|c|c|c|}
\hline Family & Scientific name & Common name & $\mathrm{ESA}^{\mathrm{a}}$ & $\mathrm{BLM}^{\mathrm{b}}$ & USFS $^{c}$ & $A Z G \& F^{d}$ \\
\hline \multirow[t]{2}{*}{ Catostomidae } & Catostomus insignis & Sonora sucker & SC & $x$ & & \\
\hline & Catostomus clarkii & desert sucker & SC & $x$ & & \\
\hline \multirow[t]{2}{*}{ Centrarchidae } & Lepomis cyanellus & green sunfish & & & & \\
\hline & Micropterus dolomieu & smallmouth bass & & & & \\
\hline \multirow[t]{4}{*}{ Cyprinidae } & Agosia chrysogaster & longfin dace & SC & $X$ & & \\
\hline & Cyprinella lutrensis & red shiner & & & & \\
\hline & Cyprinus carpio & common carp & & & & \\
\hline & Gila robusta & roundtail chub & SC & & $x$ & $X$ \\
\hline Ictaluridae & Ameiurus natalis & yellow bullhead & & & & \\
\hline
\end{tabular}

${ }^{a}$ ESA = Endangered Species Act: SC = Species of Concern (HDMS 2004).

${ }^{b} B L M=$ Bureau of Land Management: Sensitive species (HDMS 2004).

${ }^{\mathrm{c}}$ USFS $=$ U.S. Forest Service: Sensitive species (HDMS 2004).

${ }^{\mathrm{d}}$ AZG\&F = Arizona Game and Fish Department: Wildlife Species of Concern (HDMS 2004). 
Appendix D. Amphibian and reptile species observed or collected at Montezuma Castle NM. Based on Drost and Nowak (1998), unless indicated otherwise. Species in bold-faced type are non-native.

\begin{tabular}{|c|c|c|c|}
\hline Taxon & Family & Scientific name & Common name \\
\hline \multirow[t]{4}{*}{ Amphibian } & Bufonidae & Bufo woodhousii & Woodhouse's toad \\
\hline & & Bufo punctatus & red-spotted toad \\
\hline & Hylidae & Hyla arenicolor & canyon treefrog \\
\hline & Ranidae & Rana catesbeiana & American bullfrog \\
\hline \multirow[t]{30}{*}{ Reptile } & Kinosternidae & Kinosternon sonoriense & Sonoran mud turtle \\
\hline & Emydidae & Trachemys scripta & pond slider \\
\hline & Trionychidae & Trionyx spiniferus ${ }^{a}$ & spiny softshell \\
\hline & Eublepharidae & Coleonyx variegatus & western banded gecko \\
\hline & Crotaphytidae & Crotaphytus collaris & eastern collared lizard \\
\hline & Phrynosomatidae & Cophosaurus texanus & greater earless lizard \\
\hline & & Sceloporus magister & desert spiny lizard \\
\hline & & Sceloporus clarkii & Clark's spiny lizard \\
\hline & & Sceloporus undulatus & eastern fence lizard \\
\hline & & Uta stansburiana & common side-blotched lizard \\
\hline & & Urosaurus ornatus & ornate tree lizard \\
\hline & Teiidae & Cnemidophorus uniparens & desert grassland whiptail \\
\hline & & Cnemidophorus flagellicaudus & Gila spotted whiptail \\
\hline & & Cnemidophorus tigris & western whiptail (tiger whiptail) \\
\hline & Anguidae & Elgaria kingii & Madrean alligator lizard \\
\hline & Helodermatidae & Heloderma suspectum ${ }^{b}$ & Gila monster \\
\hline & Colubridae & Diadophis punctatus & ring-necked snake \\
\hline & & Masticophis flagellum & coachwhip \\
\hline & & Masticophis taeniatus & striped whipsnake \\
\hline & & Salvadora hexalepis & western patch-nosed snake \\
\hline & & Pituophis catenifer & gopher snake \\
\hline & & Arizona elegans & glossy snake \\
\hline & & Lampropeltis getula & common kingsnake \\
\hline & & Rhinocheilus lecontei & long-nosed snake \\
\hline & & Thamnophis cyrtopsis & black-necked garter snake \\
\hline & & Sonora semiannulata & western ground snake \\
\hline & & Hypsiglena torquata & night snake \\
\hline & Elapidae & Micruroides euryxanthus & Sonoran coral snake \\
\hline & Viperidae & Crotalus atrox & western diamond-backed rattlesnake \\
\hline & & Crotalus molossus & black-tailed rattlesnake \\
\hline
\end{tabular}

${ }^{a}$ Based on sighting by Paul Super (1994, unpublished notes).

${ }^{b}$ Based on sighting by park personnel 
Appendix E. Bird species observed or collected at Montezuma Castle NM. Based on Sogge et al. (In press). Underlined species are Neotropical migrants (Rappole 1995). Species in bold-faced type are non-native.

\begin{tabular}{|c|c|c|c|c|c|c|c|}
\hline Order Family & Scientific name & Common name & $\mathrm{ESA}^{a}$ & USFS $^{b}$ & $A Z G \& F^{\circ}$ & $\mathrm{APF}^{\mathrm{d}}$ & USFWS \\
\hline \multicolumn{8}{|l|}{ Anseriformes } \\
\hline \multirow[t]{22}{*}{ Anatidae } & Anser albifrons & greater white-fronted goose & & & & & \\
\hline & Chen caerulescens & snow goose & & & & & \\
\hline & Branta canadensis & Canada goose & & & & & \\
\hline & Aix sponsa & wood duck & & & & & \\
\hline & Anas strepera & gadwall & & & & & \\
\hline & Anas penelope & Eurasian wigeon & & & & & \\
\hline & Anas americana & American wigeon & & & & & \\
\hline & Anas platyrhynchos & mallard & & & & & \\
\hline & Anas discors & blue-winged teal & & & & & \\
\hline & Anas cyanoptera & cinnamon teal & & & & & \\
\hline & Anas clypeata & northern shoveler & & & & & \\
\hline & Anas acuta & northern pintail & & & & & \\
\hline & Anas crecca & green-winged teal & & & & & \\
\hline & Aythya valisineria & canvasback & & & & & \\
\hline & Aythya americana & redhead & & & & & \\
\hline & Aythya collaris & ring-necked duck & & & & & \\
\hline & Aythya affinis & lesser scaup & & & & & \\
\hline & Bucephala albeola & bufflehead & & & & & \\
\hline & Bucephala clangula & common goldeneye & & & & & \\
\hline & Lophodytes cucullatus & hooded merganser & & & & & \\
\hline & Mergus merganser & common merganser & & & & & \\
\hline & Oxyura jamaicensis & ruddy duck & & & & & \\
\hline \multicolumn{8}{|l|}{ Galliformes } \\
\hline Phasianidae & Phasianus colchicus & ring-necked pheasant & & & & & \\
\hline Odontophoridae & Callipepla gambelii & Gambel's quail & & & & & \\
\hline \multicolumn{8}{|l|}{ Podicipediformes } \\
\hline Podicipedidae & Podilymbus podiceps & pied-billed grebe & & & & & \\
\hline \multicolumn{8}{|l|}{ Ciconiiformes } \\
\hline \multirow[t]{4}{*}{ Ardeidae } & Ardea herodias & great blue heron & & & & & \\
\hline & Egretta thula & snowy egret & & & $\mathrm{X}$ & & \\
\hline & Butorides virescens & green heron & & & & & \\
\hline & Nycticorax nycticorax & black-crowned night-heron & & & & & \\
\hline Threskiornithidae & Plegadis chihi & white-faced lbis & SC & $\mathrm{X}$ & & & \\
\hline Ciconiidae & Mycteria americana & wood stork & LE & & & & \\
\hline Cathartidae & Cathartes aura & turkey vulture & & & & & \\
\hline \multicolumn{8}{|l|}{ Falconiformes } \\
\hline \multirow[t]{11}{*}{ Accipitridae } & Pandion haliaetus & osprey & & & $\mathrm{x}$ & & \\
\hline & Haliaeetus leucocephalus & bald eagle & LT & $x$ & $\mathrm{x}$ & & \\
\hline & Circus cyaneus & northern harrier & & & & & \\
\hline & Accipiter striatus & sharp-shinned hawk & & $\mathrm{X}$ & & & \\
\hline & Accipiter cooperii & Cooper's hawk & & & & & \\
\hline & Accipiter gentilis & northern goshawk & SC & $\mathrm{X}$ & $\mathrm{x}$ & & \\
\hline & Buteogallus anthracinus & common black-hawk & & $x$ & $\mathrm{x}$ & $x$ & \\
\hline & Parabuteo unicinctus & Harris's hawk & & & & & \\
\hline & Buteo swainsoni & Swainson's hawk & & & & & \\
\hline & Buteo jamaicensis & red-tailed hawk & & & & & \\
\hline & Buteo regalis & ferruginous hawk & SC & & $\mathrm{x}$ & & \\
\hline
\end{tabular}




\begin{tabular}{|c|c|c|c|c|c|c|c|}
\hline Order Family & Scientific name & Common name & $E A^{a}$ & USFS $^{b}$ & $A Z G \& F^{c}$ & $\mathrm{APF}^{\mathrm{d}}$ & USFWS \\
\hline \multicolumn{8}{|l|}{ Falconiformes } \\
\hline \multirow[t]{2}{*}{ Accipitridae } & Buteo lagopus & rough-legged hawk & & & & & \\
\hline & Aquila chrysaetos & golden eagle & & & & & \\
\hline \multirow[t]{3}{*}{ Falconidae } & Falco sparverius & American kestrel & & & & & \\
\hline & Falco columbarius & merlin & & & & & \\
\hline & Falco peregrinus & peregrine falcon & SC & & $X$ & & $X$ \\
\hline \multicolumn{8}{|l|}{ Gruiformes } \\
\hline \multirow[t]{4}{*}{ Rallidae } & Rallus limicola & Virginia rail & & & & & \\
\hline & Porzana carolina & sora & & & & & \\
\hline & Gallinula chloropus & common moorhen & & & & & \\
\hline & Fulica americana & American coot & & & & & \\
\hline \multicolumn{8}{|l|}{ Charadriformes } \\
\hline \multirow[t]{2}{*}{ Charadriidae } & Pluvialis squatarola & black-bellied plover & & & & & \\
\hline & Charadrius vociferus & killdeer & & & & & \\
\hline \multirow[t]{5}{*}{ Scolopacidae } & Catoptrophorus semipalmatus & willet & & & & & \\
\hline & Actitis macularis & spotted sandpiper & & & & & \\
\hline & Calidris bairdii & Baird's sandpiper & & & & & \\
\hline & Gallinago gallinago & common snipe & & & & & \\
\hline & Phalaropus tricolor & Wilson's phalarope & & & & & \\
\hline \multicolumn{8}{|l|}{ Columbiformes } \\
\hline \multirow[t]{4}{*}{ Columbidae } & Columba livia & rock pigeon & & & & & \\
\hline & Zenaida asiatica & white-winged dove & & & & & \\
\hline & Zenaida macroura & mourning dove & & & & & \\
\hline & Columbina passerina & common ground-dove & & & & & \\
\hline \multicolumn{8}{|l|}{ Cuculiformes } \\
\hline \multirow[t]{2}{*}{ Cuculidae } & Coccyzus americanus & yellow-billed cuckoo & C & $x$ & $x$ & $x$ & $x$ \\
\hline & Geococcyx californianus & greater roadrunner & & & & & \\
\hline \multicolumn{8}{|l|}{ Strigiformes } \\
\hline Tytonidae & Tyto alba & barn owl & & & & & \\
\hline \multirow[t]{5}{*}{ Strigidae } & Megascops kennicottii & western screech-owl & & & & & \\
\hline & Bubo virginianus & great horned owl & & & & & \\
\hline & Glaucidium gnoma & northern pygmy-owl & & & & & \\
\hline & Micrathene whitneyi & elf owl & & & & & $x$ \\
\hline & Asio flammeus & short-eared owl & & & & & \\
\hline \multicolumn{8}{|l|}{ Caprimulgiformes } \\
\hline \multirow[t]{3}{*}{ Caprimulgidae } & Chordeiles acutipennis & lesser nighthawk & & & & & \\
\hline & Chordeiles minor & common nighthawk & & & & & \\
\hline & Phalaenoptilus nuttallii & common poorwill & & & & & \\
\hline \multicolumn{8}{|l|}{ Apodiformes } \\
\hline \multirow[t]{2}{*}{ Apodidae } & Chaetura vauxi & Vaux's swift & & & & & \\
\hline & Aeronautes saxatalis & white-throated swift & & & & & \\
\hline \multirow[t]{6}{*}{ Trochilidae } & Lampornis clemenciae & blue-throated hummingbird & & & & & \\
\hline & Archilochus alexandri & black-chinned hummingbird & & & & & \\
\hline & Calypte anna & Anna's hummingbird & & & & & \\
\hline & Calypte costae & Costa's hummingbird & & & & $X$ & \\
\hline & Selasphorus platycercus & broad-tailed hummingbird & & & & & \\
\hline & Selasphorus rufus & rufous hummingbird & & & & & \\
\hline \multicolumn{8}{|l|}{ Coraciiformes } \\
\hline Alcedinidae & Ceryle alcyon & belted kingfisher & & & $X$ & & \\
\hline
\end{tabular}




\begin{tabular}{|c|c|c|c|c|c|c|c|}
\hline Order Family & Scientific name & Common name & $\mathrm{ESA}^{\mathrm{a}}$ & USFS $^{b}$ & $A Z G \& F^{c}$ & $\mathrm{APF}^{\mathrm{d}}$ & USFWS $^{e}$ \\
\hline \multicolumn{8}{|l|}{ Piciformes } \\
\hline \multirow[t]{7}{*}{ Picidae } & Melanerpes lewis & Lewis's woodpecker & & & & & \\
\hline & Melanerpes erythrocephalus & red-headed woodpecker & & & & & \\
\hline & Melanerpes uropygialis & Gila woodpecker & & & & & $x$ \\
\hline & Sphyrapicus thyroideus & Williamson's sapsucker & & & & & \\
\hline & Sphyrapicus nuchalis & red-naped sapsucker & & & & & \\
\hline & Picoides scalaris & ladder-backed woodpecker & & & & & \\
\hline & Colaptes auratus & northern flicker & & & & & \\
\hline \multicolumn{8}{|l|}{ Passeriformes } \\
\hline \multirow[t]{13}{*}{ Tyrannidae } & Camptostoma imberbe & northern beardless-tyrannulet & & & & & \\
\hline & Contopus cooperi & olive-sided flycatcher & SC & & & & \\
\hline & Contopus sordidulus & western wood-pewee & & & & & \\
\hline & Empidonax traillii & willow flycatcher & & & $x$ & & \\
\hline & Empidonax wrightii & gray flycatcher & & & & & \\
\hline & Empidonax occidentalis or difficilis & western flycatcher & & & & & \\
\hline & Sayornis nigricans & black phoebe & & & & & \\
\hline & Sayornis saya & Say's phoebe & & & & & \\
\hline & Pyrocephalus rubinus & vermilion flycatcher & & & & & \\
\hline & Myiarchus cinerascens & ash-throated flycatcher & & & & & \\
\hline & Myiarchus tyrannulus & brown-crested flycatcher & & & & & \\
\hline & Tyrannus vociferans & Cassin's kingbird & & & & & \\
\hline & Tyrannus verticalis & western kingbird & & & & & \\
\hline Laniidae & Lanius ludovicianus & loggerhead shrike & SC & $x$ & & & \\
\hline \multirow[t]{5}{*}{ Vireonidae } & Vireo bellii & Bell's vireo & & $x$ & & & $x$ \\
\hline & Vireo vicinior & gray vireo & & & & & \\
\hline & Vireo plumbeus & plumbeous vireo & & & & & \\
\hline & Vireo huttoni & Hutton's vireo & & & & & \\
\hline & Vireo gilvus & warbling vireo & & & & & \\
\hline \multirow[t]{6}{*}{ Corvidae } & Cyanocitta stelleri & Steller's jay & & & & & \\
\hline & Aphelocoma californica & western scrub-jay & & & & & \\
\hline & Aphelocoma ultramarina & Mexican jay & & & & & \\
\hline & Gymnorhinus cyanocephalus & pinyon jay & & & & & \\
\hline & Corvus brachyrhynchos & American crow & & & & & \\
\hline & Corvus corax & common raven & & & & & \\
\hline Alaudidae & Eremophila alpestris & horned lark & & & & & \\
\hline \multirow[t]{5}{*}{ Hirundinidae } & Progne subis & purple martin & & & & $X$ & \\
\hline & Tachycineta thalassina & violet-green swallow & & & & & \\
\hline & Stelgidopteryx serripennis & northern rough-winged swallow & & & & & \\
\hline & Riparia riparia & bank swallow & & & & & \\
\hline & Petrochelidon pyrrhonota & cliff swallow & & & & & \\
\hline \multirow[t]{3}{*}{ Paridae } & Poecile gambeli & mountain chickadee & & & & & \\
\hline & Baeolophus wollweberi & bridled titmouse & & & & & \\
\hline & Baeolophus ridgwayi & juniper titmouse & & & & & \\
\hline Remizidae & Auriparus flaviceps & verdin & & & & & \\
\hline Aegithalidae & Psaltriparus minimus & bushtit & & & & & \\
\hline \multirow[t]{2}{*}{ Sittidae } & Sitta carolinensis & white-breasted nuthatch & & & & & \\
\hline & Sitta pygmaea & pygmy nuthatch & & & & & \\
\hline Certhiidae & Certhia americana & brown creeper & & & & & \\
\hline \multirow[t]{2}{*}{ Troglodytidae } & Campylorhynchus brunneicapillus & cactus wren & & & & & \\
\hline & Salpinctes obsoletus & rock wren & & & & & \\
\hline
\end{tabular}




\begin{tabular}{|c|c|c|c|c|c|c|c|}
\hline Order Family & Scientific name & Common name & $E A^{a}$ & USFS $^{b}$ & $A Z G \& F^{c}$ & $\mathrm{APF}^{\mathrm{d}}$ & USFWS \\
\hline \multicolumn{8}{|l|}{ Passeriformes } \\
\hline \multirow[t]{4}{*}{ Troglodytidae } & Catherpes mexicanus & canyon wren & & & & & \\
\hline & Thryomanes bewickii & Bewick's wren & & & & & \\
\hline & Troglodytes aedon & house wren & & & & & \\
\hline & Cistothorus palustris & marsh wren & & & & & \\
\hline Regulidae & Regulus calendula & ruby-crowned kinglet & & & & & \\
\hline Sylviidae & Polioptila caerulea & blue-gray gnatcatcher & & & & & \\
\hline \multirow[t]{5}{*}{ Turdidae } & Sialia mexicana & western bluebird & & & & & \\
\hline & Sialia currucoides & mountain bluebird & & & & & \\
\hline & Myadestes townsendi & Townsend's solitaire & & & & & \\
\hline & Catharus guttatus & hermit thrush & & & & & \\
\hline & Turdus migratorius & American robin & & & & & \\
\hline \multirow[t]{4}{*}{ Mimidae } & Mimus polyglottos & northern mockingbird & & & & & \\
\hline & Oreoscoptes montanus & sage thrasher & & & & & \\
\hline & Toxostoma rufum & brown thrasher & & & & & \\
\hline & Toxostoma crissale & crissal thrasher & & & & & $X$ \\
\hline Sturnidae & Sturnus vulgaris & European starling & & & & & \\
\hline Motacillidae & Anthus rubescens & American pipit & & & & & \\
\hline Bombycillidae & Bombycilla cedrorum & cedar waxwing & & & & & \\
\hline Ptilogonatidae & Phainopepla nitens & phainopepla & & & & & \\
\hline \multirow[t]{17}{*}{ Parulidae } & Vermivora chrysoptera & golden-winged warbler & & & & & \\
\hline & Vermivora celata & orange-crowned warbler & & & & & \\
\hline & Vermivora ruficapilla & Nashville warbler & & & & & \\
\hline & Vermivora virginiae & Virginia's warbler & & & & & \\
\hline & Vermivora luciae & Lucy's warbler & & & & $x$ & \\
\hline & Dendroica petechia & yellow warbler & & & & & \\
\hline & Dendroica caerulescens & black-throated blue warbler & & & & & \\
\hline & Dendroica coronata & yellow-rumped warbler & & & & & \\
\hline & Dendroica nigrescens & black-throated gray warbler & & & & & \\
\hline & Dendroica townsendi & Townsend's warbler & & & & & \\
\hline & Dendroica graciae & Grace's warbler & & & & & \\
\hline & Seiurus noveboracensis & northern waterthrush & & & & & \\
\hline & Oporornis tolmiei & MacGillivray's warbler & & & & & \\
\hline & Geothlypis trichas & common yellowthroat & & & & & \\
\hline & Wilsonia citrina & hooded warbler & & & & & \\
\hline & Wilsonia pusilla & Wilson's warbler & & & & & \\
\hline & Icteria virens & yellow-breasted chat & & & & & \\
\hline \multirow[t]{3}{*}{ Thraupidae } & Piranga flava & hepatic tanager & & & & & \\
\hline & Piranga rubra & summer tanager & & & & & \\
\hline & Piranga ludoviciana & western tanager & & & & & \\
\hline \multirow[t]{10}{*}{ Emberizidae } & Pipilo chlorurus & green-tailed towhee & & & & & \\
\hline & Pipilo maculatus & spotted towhee & & & & & \\
\hline & Pipilo fuscus & canyon towhee & & & & & \\
\hline & Pipilo aberti & Abert's towhee & & & & & \\
\hline & Aimophila ruficeps & rufous-crowned sparrow & & & & & \\
\hline & Spizella arborea & American tree sparrow & & & & & \\
\hline & Spizella passerina & chipping sparrow & & & & & \\
\hline & Spizella breweri & Brewer's sparrow & & & & & \\
\hline & Spizella atrogularis & black-chinned sparrow & & & & & \\
\hline & Pooecetes gramineus & vesper sparrow & & & & & \\
\hline
\end{tabular}




\begin{tabular}{|c|c|c|c|c|c|c|c|c|}
\hline Order & Family & Scientific name & Common name & $\mathrm{ESA}^{\mathrm{a}}$ & USFS $^{b}$ & $A Z G \& F^{c}$ & $\mathrm{APF}^{\mathrm{d}}$ & USFWS \\
\hline \multicolumn{9}{|c|}{ Passeriformes } \\
\hline \multirow{8}{*}{\multicolumn{2}{|c|}{ Emberizidae }} & Chondestes grammacus & lark sparrow & & & & & \\
\hline & & Melospiza lincolnii & Lincoln's sparrow & & & & & \\
\hline & & Amphispiza bilineata & black-throated sparrow & & & & & \\
\hline & & Amphispiza belli & sage sparrow & & & & & \\
\hline & & Melospiza melodia & song sparrow & & & & & \\
\hline & & Zonotrichia albicollis & white-throated sparrow & & & & & \\
\hline & & Zonotrichia leucophrys & white-crowned sparrow & & & & & \\
\hline & & Junco hyemalis & dark-eyed junco & & & & & \\
\hline \multirow{5}{*}{\multicolumn{2}{|c|}{ Cardinalidae }} & Cardinalis cardinalis & northern cardinal & & & & & \\
\hline & & Pheucticus melanocephalus & black-headed grosbeak & & & & & \\
\hline & & Passerina caerulea & blue grosbeak & & & & & \\
\hline & & Passerina amoena & lazuli bunting & & & & & \\
\hline & & Passerina cyanea & indigo bunting & & & & & \\
\hline \multirow{9}{*}{\multicolumn{2}{|c|}{ Icteridae }} & Agelaius phoeniceus & red-winged blackbird & & & & & \\
\hline & & Sturnella neglecta & western meadowlark & & & & & \\
\hline & & Xanthocephalus xanthocephalus & yellow-headed blackbird & & & & & \\
\hline & & Euphagus cyanocephalus & Brewer's blackbird & & & & & \\
\hline & & Quiscalus mexicanus & great-tailed grackle & & & & & \\
\hline & & Molothrus ater & brown-headed cowbird & & & & & \\
\hline & & Icterus cucullatus & hooded oriole & & & & & \\
\hline & & Icterus bullockii & Bullock's oriole & & & & & \\
\hline & & Icterus parisorum & Scott's oriole & & & & & \\
\hline \multirow{8}{*}{\multicolumn{2}{|c|}{ Fringillidae }} & Carpodacus purpureus & purple finch & & & & & \\
\hline & & Carpodacus cassinii & Cassin's finch & & & & & \\
\hline & & Carpodacus mexicanus & house finch & & & & & \\
\hline & & Loxia curvirostra & red crossbill & & & & & \\
\hline & & Carduelis pinus & pine siskin & & & & & \\
\hline & & Carduelis psaltria & lesser goldfinch & & & & & \\
\hline & & Carduelis tristis & American goldfinch & & & & & \\
\hline & & Coccothraustes vespertinus & evening grosbeak & & & & & \\
\hline & Passeridae & Passer domesticus & house sparrow & & & & & \\
\hline
\end{tabular}

${ }^{a}$ ESA = Endangered Species Act: SC = Species of Concern, LT = Listed as Threatened, LE = Listed as Endangered, $\mathrm{C}=$ Candidate species (HDMS 2005).

${ }^{\mathrm{b}}$ USFS $=$ U.S. Forest Service: Sensitive species (HDMS 2004).

${ }^{c}$ AZG\&F = Arizona Game and Fish Department: Wildlife Species of Concern (HDMS 2004).

${ }^{\mathrm{d}}$ APF $=$ Arizona Partners in Flight: Priority species (Latta et al. 1999).

${ }^{\mathrm{e}}$ USFWS $=$ U.S. Fish and Wildlife Service: Bird of Conservation Concern (USFWS 2002). 
Appendix F. Mammal species observed or collected at Montezuma Castle NM. Based on Drost and Ellison (D\&E; 1996) and Bucci and Petryszyn (B\&P; 2004). Species in bold-face type are non-native.

\begin{tabular}{|c|c|c|c|c|c|c|c|c|}
\hline Order Family & Scientific name & Common name & $\mathrm{D} \& \mathrm{E}$ & $B \& P$ & $\mathrm{ESA}^{\mathrm{a}}$ & $\mathrm{BLM}^{\mathrm{b}}$ & USFS $^{c}$ & $A Z G \& F^{d}$ \\
\hline \multicolumn{9}{|l|}{ Insectivora } \\
\hline Soricidae & Notiosorex crawfordi & Crawford's desert shrew & $x$ & & & & & \\
\hline \multicolumn{9}{|l|}{ Chiroptera } \\
\hline \multirow[t]{15}{*}{ Vespertilionidae } & Myotis occultus & Arizona myotis & & $X$ & SC & $X$ & & \\
\hline & Myotis yumanensis & Yuma myotis & $x$ & $x$ & SC & & & \\
\hline & Myotis auriculus & southwestern myotis & & $X$ & & & & \\
\hline & Myotis velifer & cave myotis & $X$ & $x$ & SC & $X$ & & \\
\hline & Myotis thysanodes & fringed myotis & $x$ & $x$ & SC & $x$ & & \\
\hline & Myotis californicus & California myotis & $x$ & $x$ & & & & \\
\hline & Myotis ciliolabrum & western small-footed myotis & $x$ & $x$ & SC & $x$ & & \\
\hline & Pipistrellus hesperus & western pipistrelle & $x$ & $x$ & & & & \\
\hline & Eptesicus fuscus & big brown bat & $x$ & $X$ & & & & \\
\hline & Euderma maculatum & spotted bat & & $X$ & SC & & $X$ & $X$ \\
\hline & Lasiurus blossevillii & western red bat & & $x$ & & & & $x$ \\
\hline & Lasiurus cinereus & hoary bat & & $x$ & & & & \\
\hline & Corynorhinus townsendii & Townsend's big-eared bat & $x$ & $X$ & SC & & & \\
\hline & Idionycteris phyllotis & Allen's big-eared bat & & $x$ & SC & $\mathrm{X}$ & & \\
\hline & Antrozous pallidus & pallid bat & $X$ & $x$ & & & & \\
\hline \multirow[t]{3}{*}{ Molossidae } & Tadarida brasiliensis & Brazilian free-tailed bat & $x$ & $x$ & & & & \\
\hline & Nyctinomops femorosaccus & pocketed free-tailed bat & & $x$ & & $x$ & & \\
\hline & Nyctinomops macrotis & big free-tailed bat & & $x$ & SC & $x$ & & \\
\hline \multicolumn{9}{|l|}{ Carnivora } \\
\hline Ursidae & Ursus americanus & American black bear & $x$ & & & & & \\
\hline \multirow[t]{2}{*}{ Procyonidae } & Procyon lotor & northern raccoon & $X$ & & & & & \\
\hline & Bassariscus astutus & ringtail & $x$ & & & & & \\
\hline \multirow[t]{2}{*}{ Mustelidae } & Taxidea taxus & American badger & $x$ & & & & & \\
\hline & Lontra canadensis & southwestern river otter & $x$ & & SC & & $x$ & $x$ \\
\hline \multirow[t]{2}{*}{ Mephitidae } & Mephitis mephitis & striped skunk & $x$ & & & & & \\
\hline & Conepatus mesoleucus & white-backed hog-nosed skunk & $x$ & & & & & \\
\hline \multirow[t]{2}{*}{ Canidae } & Canis latrans & coyote & $x$ & & & & & \\
\hline & Urocyon cinereoargenteus & common gray fox & $x$ & & & & & \\
\hline \multirow[t]{3}{*}{ Felidae } & Felis catus & feral cat & $x$ & & & & & \\
\hline & Puma concolor & mountain lion & $x$ & & & & & \\
\hline & Lynx rufus & bobcat & $x$ & & & & & \\
\hline \multicolumn{9}{|l|}{ Rodentia } \\
\hline \multirow[t]{4}{*}{ Sciuridae } & Spermophilus variegatus & rock squirrel & $X$ & & & & & \\
\hline & Ammospermophilus harrisii & Harris' antelope squirrel & $x$ & & & & & \\
\hline & Neotamias dorsalis & cliff chipmunk & $X$ & & & & & \\
\hline & Sciurus arizonensis & Arizona gray squirrel & $x$ & & SC & & & \\
\hline Geomyidae & Thomomys bottae & Botta's pocket gopher & $X$ & & & & & \\
\hline \multirow[t]{2}{*}{ Heteromyidae } & Chaetodipus intermedius & rock pocket mouse & $x$ & & SC & & & \\
\hline & Dipodomys ordii & Ord's kangaroo rat & $x$ & & & & & \\
\hline Castoridae & Castor canadensis & American beaver & $x$ & & & & & \\
\hline \multirow[t]{5}{*}{ Muridae } & Reithrodontomys megalotis & western harvest mouse & $x$ & & & & & \\
\hline & Peromyscus eremicus & cactus mouse & $x$ & & SC & & $X$ & \\
\hline & Peromyscus maniculatus & deer mouse & $x$ & & & & & \\
\hline & Peromyscus leucopus & white-footed mouse & $x$ & & & & & \\
\hline & Peromyscus boylii & brush mouse & $x$ & & & & & \\
\hline
\end{tabular}




\begin{tabular}{|c|c|c|c|c|c|c|c|c|c|}
\hline Order & Family & Scientific name & Common name & D\&E & B\&P & $\mathrm{ESA}^{\mathrm{a}}$ & $\mathrm{BLM}^{\mathrm{b}}$ & USFS $^{c}$ & $A Z G \& F^{d}$ \\
\hline \multicolumn{10}{|c|}{ Rodentia } \\
\hline \multirow{6}{*}{\multicolumn{2}{|c|}{ Muridae }} & Peromyscus truei & pinon mouse & $x$ & & & & & \\
\hline & & Onychomys leucogaster & northern grasshopper mouse & $x$ & & & & & \\
\hline & & Neotoma albigula & western white-throated woodrat & $x$ & & & & & \\
\hline & & Neotoma mexicana & Mexican woodrat & $x$ & & SC & & & \\
\hline & & Neotoma stephensi & Stephens' woodrat & $x$ & & & & & \\
\hline & & Ondatra zibethicus & common muskrat & $x$ & & & & & \\
\hline & Erethizontidae & Erethizon dorsatum & North American porcupine & $X$ & & & & & \\
\hline \multicolumn{10}{|c|}{ Lagomorpha } \\
\hline \multirow{3}{*}{\multicolumn{2}{|c|}{ Leporidae }} & Lepus californicus & black-tailed jackrabbit & $X$ & & & & & \\
\hline & & Sylvilagus floridanus & eastern cottontail & $x$ & & & & & \\
\hline & & Sylvilagus audubonii & desert cottontail & $X$ & & & & & \\
\hline \multicolumn{10}{|c|}{ Artiodactyla } \\
\hline & Tayassuidae & Pecari tajacu & collared peccary & $X$ & & & & & \\
\hline \multirow{3}{*}{\multicolumn{2}{|c|}{ Cervidae }} & Cervus canadensis & wapiti & $X$ & & & & & \\
\hline & & Odocoileus hemionus & mule deer & $X$ & & & & & \\
\hline & & Odocoileus virginianus & white-tailed deer & $X$ & & & & & \\
\hline
\end{tabular}

${ }^{a}$ ESA = Endangered Species Act: SC = Species of Concern (HDMS 2005).

${ }^{\mathrm{b}} \mathrm{BLM}=$ Bureau of Land Management: Sensitive species (HDMS 2005).

${ }^{\mathrm{C}}$ USFS $=$ U.S. Forest Service: Sensitive species (HDMS 2005).

${ }^{\mathrm{d}}$ AZG\&F = Arizona Game and Fish Department: Wildlife Species of Concern (HDMS 2005). 
Appendix G. Native fish species that have been extirpated (E) and non-native fish that no longer occur (NP) at Montezuma Castle NM. Based on Montgomery et al. (1995). Species in bold-faced type are non-native.

\begin{tabular}{lllc}
\hline Family & Scientific name & Common name & Status \\
\hline Centrarchidae & Micropterus punctulatus & spotted bass & NP \\
\hline \multirow{2}{*}{ Cyprinidae } & Micropterus salmoides & largemouth bass & NP \\
& Meda fulgida & spikedace & $\mathrm{E}$ \\
& Rhinichthys osculus & speckled dace & $\mathrm{E}$ \\
\hline Ictaluridae & Rhinichthys cobitis & loach minnow & $\mathrm{E}$ \\
& Ameiurus melas & black bullhead & NP \\
& Ictalurus punctatus & channel catfish & NP \\
\hline
\end{tabular}

Appendix H. Amphibian and reptile species that may occur (P) or have been extirpated (E) at Montezuma Castle NM. Based on Drost and Nowak (D\&N; 1998) and observations from nearby Tuzigoot NM (Schmidt et al. 2005; Sch).

\begin{tabular}{|c|c|c|c|c|c|}
\hline Taxon & Family & Scientific name & Common name & $\mathrm{D \& N}$ & Sch \\
\hline \multirow[t]{2}{*}{ Amphibian } & Bufonidae & Bufo microscaphus & Arizona toad & $E$ & \\
\hline & & Rana yavapaiensis & lowland leopard frog & $E$ & \\
\hline \multirow[t]{7}{*}{ Reptile } & Phrynosomatidae & Phrynosoma hernandesi & greater short-horned lizard & $P$ & \\
\hline & Leptotyphlopidae & Leptotyphlops humilis & western blind snake & & $P$ \\
\hline & Colubridae & Masticophis bilineatus & Sonoran whipsnake & & $P$ \\
\hline & & Thamnophis eques & Mexican garter snake & & $P$ \\
\hline & & Tantilla hobartsmithi & southwestern black-headed snake & & $\mathrm{P}$ \\
\hline & & Trimorphodon biscutatus & western lyre snake & $P$ & $P$ \\
\hline & Viperidae & Crotalus scutulatus & Mojave rattlesnake & $P$ & \\
\hline
\end{tabular}


Appendix I. Bird species that may occur at Montezuma Castle NM. Based on Sogge et al. (Sog; In press), and observations from near the monument by the National Audubon Society Christmas Bird Count (CBC; No date), Tuzigoot inventory (Schmidt et al. 2005;Sch), and Larry Norris (LN). Underlined species are Neotropical migrants (Rappole 1995).

\begin{tabular}{|c|c|c|c|c|c|c|}
\hline Order Family & Scientific name & Common name & Sog & $\mathrm{CBC}$ & Sch & $\mathrm{LN}$ \\
\hline \multicolumn{7}{|l|}{ Anseriformes } \\
\hline \multirow[t]{2}{*}{ Anatidae } & Cygnus columbianus & tundra swan & & & $\mathrm{x}$ & \\
\hline & Mergus serrator & red-breasted merganser & $x$ & & & \\
\hline \multicolumn{7}{|l|}{ Gaviiformes } \\
\hline Gaviidae & Gavia immer & common loon & & & $x$ & \\
\hline \multicolumn{7}{|l|}{ Podicipediformes } \\
\hline \multirow[t]{2}{*}{ Podicipedidae } & Podiceps nigricollis & eared grebe & & $\mathrm{x}$ & $\mathrm{x}$ & \\
\hline & Aechmophorus occidentalis & western grebe & & & $x$ & \\
\hline \multicolumn{7}{|l|}{ Pelecaniformes } \\
\hline Pelecanidae & Pelecanus erythrorhynchos & American white pelican & & & $x$ & \\
\hline Phalacrocoracidae & Phalacrocorax auritus & double-crested cormorant & & & $\mathrm{x}$ & \\
\hline \multicolumn{7}{|l|}{ Ciconiiformes } \\
\hline \multirow[t]{5}{*}{ Ardeidae } & Botaurus lentiginosus & American bittern & & & $x$ & \\
\hline & lxobrychus exilis & least bittern & & & $\underline{x}$ & \\
\hline & Ardea alba & great egret & & & $\mathrm{x}$ & \\
\hline & Egretta caerulea & little blue heron & & & $x$ & \\
\hline & Bubulcus ibis & cattle egret & $x$ & & $x$ & \\
\hline \multicolumn{7}{|l|}{ Falconiformes } \\
\hline Accipitridae & Buteo albonotatus & zone-tailed hawk & & & $\mathrm{x}$ & \\
\hline \multirow[t]{2}{*}{ Falconidae } & Caracara cheriway & crested caracara & & & $x$ & \\
\hline & Falco mexicanus & prairie falcon & & $\mathrm{x}$ & $\mathrm{x}$ & \\
\hline \multicolumn{7}{|l|}{ Gruiformes } \\
\hline Rallidae & Rallus longirostris yumanensis & Yuma clapper rail & & & $\mathrm{x}$ & \\
\hline \multicolumn{7}{|l|}{ Charadriiformes } \\
\hline \multirow[t]{2}{*}{ Recurvirostridae } & Himantopus mexicanus & black-necked stilt & & & $x$ & \\
\hline & Recurvirostra americana & American avocet & & & $x$ & \\
\hline \multirow[t]{9}{*}{ Scolopacidae } & Tringa melanoleuca & greater yellowlegs & & & $x$ & \\
\hline & Tringa flavipes & lesser yellowlegs & & & $x$ & \\
\hline & Tringa solitaria & solitary sandpiper & & & $x$ & \\
\hline & Numenius americanus & long-billed curlew & & & $\mathrm{x}$ & \\
\hline & Limosa fedoa & marbled godwit & & & $x$ & \\
\hline & Calidris mauri & western sandpiper & & & $x$ & \\
\hline & Calidris minutilla & least sandpiper & & & $x$ & \\
\hline & Limnodromus scolopaceus & long-billed dowitcher & & & $x$ & \\
\hline & Phalaropus lobatus & red-necked phalarope & & & $x$ & \\
\hline \multirow[t]{7}{*}{ Laridae } & Larus pipixcan & Franklin's gull & & & $x$ & \\
\hline & Larus philadelphia & Bonaparte's gull & & & $x$ & \\
\hline & Larus delawarensis & ring-billed gull & & & $\mathrm{x}$ & \\
\hline & Larus californicus & California gull & & & $x$ & \\
\hline & Xema sabini & Sabine's gull & & & $x$ & \\
\hline & Sterna forsteri & Forster's tern & & & $x$ & \\
\hline & Chlidonias niger & Black tern & & & $\mathrm{x}$ & \\
\hline \multicolumn{7}{|l|}{ Columbiformes } \\
\hline Columbidae & Columbina inca & Inca dove & & $\mathrm{x}$ & $\mathrm{x}$ & \\
\hline \multicolumn{7}{|l|}{ Cuculiformes } \\
\hline Cuculidae & Crotophaga sulcirostris & groove-billed ani & $\mathrm{x}$ & & & \\
\hline
\end{tabular}




\begin{tabular}{|c|c|c|c|c|c|c|}
\hline Order Family & Scientific name & Common name & Sog & $\mathrm{CBC}$ & Sch & $\mathrm{LN}$ \\
\hline \multicolumn{7}{|l|}{ Strigiformes } \\
\hline \multirow[t]{2}{*}{ Strigidae } & Asio otus & long-eared owl & & & $x$ & \\
\hline & Aegolius acadicus & northern saw-whet owl & & & $x$ & \\
\hline \multicolumn{7}{|l|}{ Apodiformes } \\
\hline Trochilidae & Stellula calliope & calliope hummingbird & & & $x$ & \\
\hline \multicolumn{7}{|l|}{ Piciformes } \\
\hline \multirow[t]{4}{*}{ Picidae } & Melanerpes formicivorus & acorn woodpecker & & $x$ & $x$ & \\
\hline & Sphyrapicus varius & yellow-bellied sapsucker & & $x$ & $x$ & \\
\hline & Picoides pubescens & downy woodpecker & & $x$ & & $X$ \\
\hline & Picoides villosus & hairy woodpecker & & $x$ & $X$ & \\
\hline \multicolumn{7}{|l|}{ Passeriformes } \\
\hline \multirow[t]{3}{*}{ Tyrannidae } & Empidonax hammondii & Hammond's flycatcher & & & $x$ & \\
\hline & Empidonax oberholseri & dusky flycatcher & & & $x$ & \\
\hline & Myiarchus tuberculifer & dusky-capped flycatcher & & & $x$ & \\
\hline \multirow[t]{2}{*}{ Hirundinidae } & Tachycineta bicolor & tree swallow & & & $x$ & \\
\hline & Hirundo rustica & barn swallow & & & $x$ & \\
\hline Sittidae & Sitta canadensis & red-breasted nuthatch & & $x$ & & \\
\hline Troglodytidae & Troglodytes troglodytes & winter wren & & & $x$ & \\
\hline Regulidae & Regulus satrapa & golden-crowned kinglet & & $x$ & & \\
\hline Sylviidae & Polioptila melanura & black-tailed gnatcatcher & & & $x$ & \\
\hline Turdidae & Catharus ustulatus & Swainson's thrush & $x$ & & $x$ & \\
\hline \multirow[t]{3}{*}{ Mimidae } & Toxostoma bendirei & Bendire's thrasher & & & $x$ & \\
\hline & Toxostoma curvirostre & curve-billed thrasher & & $x$ & & \\
\hline & Toxostoma lecontei & Le Conte's thrasher & $x$ & & $x$ & \\
\hline \multirow[t]{3}{*}{ Parulidae } & Dendroica occidentalis & hermit warbler & & & $x$ & \\
\hline & Cardellina rubrifrons & red-faced warbler & & & $x$ & \\
\hline & Myioborus pictus & painted redstart & & & $x$ & \\
\hline \multirow[t]{4}{*}{ Emberizidae } & Passerculus sandwichensis & savannah sparrow & & $x$ & $x$ & \\
\hline & Calamospiza melanocorys & lark bunting & $x$ & $x$ & $x$ & \\
\hline & Passerella iliaca & fox sparrow & & $x$ & & \\
\hline & Calcarius ornatus & chestnut-collared longspur & & $x$ & & \\
\hline \multirow[t]{3}{*}{ Icteridae } & Sturnella magna & eastern meadowlark & & & $x$ & \\
\hline & Quiscalus quiscula & common grackle & & & $x$ & \\
\hline & Molothrus aeneus & bronzed cowbird & $x$ & & $x$ & \\
\hline Fringillidae & Carduelis lawrencei & Lawrence's goldfinch & & $X$ & $x$ & \\
\hline
\end{tabular}


Appendix J. Mammal species that may occur at Montezuma Castle NM. Based on Drost and Ellison (1996).

\begin{tabular}{|c|c|c|c|}
\hline Order & Family & Scientific name & Common name \\
\hline \multirow[t]{3}{*}{ Chiroptera } & Vespertilionidae & Myotis leibii & eastern small-footed myotis \\
\hline & & Lasionycteris noctivagans & silver-haired bat \\
\hline & Molossidae & Eumops perotis & western bonneted bat \\
\hline \multirow[t]{3}{*}{ Carnivora } & Procyonidae & Nasua narica & white-nosed coati \\
\hline & Mephitidae & Spilogale gracilis & western spotted skunk \\
\hline & & Mephitis macroura & hooded skunk \\
\hline \multirow[t]{6}{*}{ Rodentia } & Sciuridae & Spermophilus lateralis & golden-mantled ground squirrel \\
\hline & Heteromyidae & Perognathus amplus & Arizona pocket mouse \\
\hline & & Chaetodipus hispidus & hispid pocket mouse \\
\hline & Muridae & Reithrodontomys montanus & Plains harvest mouse \\
\hline & & Onychomys torridus & southern grasshopper mouse \\
\hline & & Mus musculus & house mouse \\
\hline
\end{tabular}

\section{Appendix K. Voucher specimens from Montezuma Castle NM.}

\begin{tabular}{|c|c|c|c|c|c|}
\hline Taxon & Common name & Collection no. & Collection $^{\mathrm{a}}$ & Date collected & Collector \\
\hline Amphibian & Arizona toad & & FWMSH & $08 / 14 / 77$ & W. Voss \\
\hline \multirow[t]{6}{*}{ Reptile } & Sonoran mud turtle & 1012 & WACC & & \\
\hline & greater earless lizard & 27882 & UI & $06 / 14 / 51$ & D. M. Smith and H. M. Smith \\
\hline & Clark's spiny lizard & 12421 & CAS & $01 / 01 / 50$ & D. E. Kidd \\
\hline & ornate tree lizard & 6508 & UC & $04 / 23 / 53$ & T. P. Maslin \\
\hline & western patch-nosed snake & 11726 & CAS & $05 / 09 / 49$ & H. K. Gloyd and K. Gloyd \\
\hline & black-necked garter snake & 84308 & UI & $08 / 07 / 55$ & D. M. Smith, R. Urbano and F. A. Shannon \\
\hline Bird & gray flycatcher & 383 & UA & & \\
\hline Mammal & pronghorn & 9057 & WACC & $03 / 00 / 59$ & \\
\hline
\end{tabular}

${ }^{\mathrm{a}} \mathrm{CAS}=$ Chicago Academy of Science, FWMSH = Fort Worth Museum of Science and History, UA = University of Arizona, $U C=$ University of Colorado Museum, UI = University of Illinois Museum of Natural History, WACC = Western Archaeological Conservation Center. 
